BNL 5 I 202

Dr. 1934

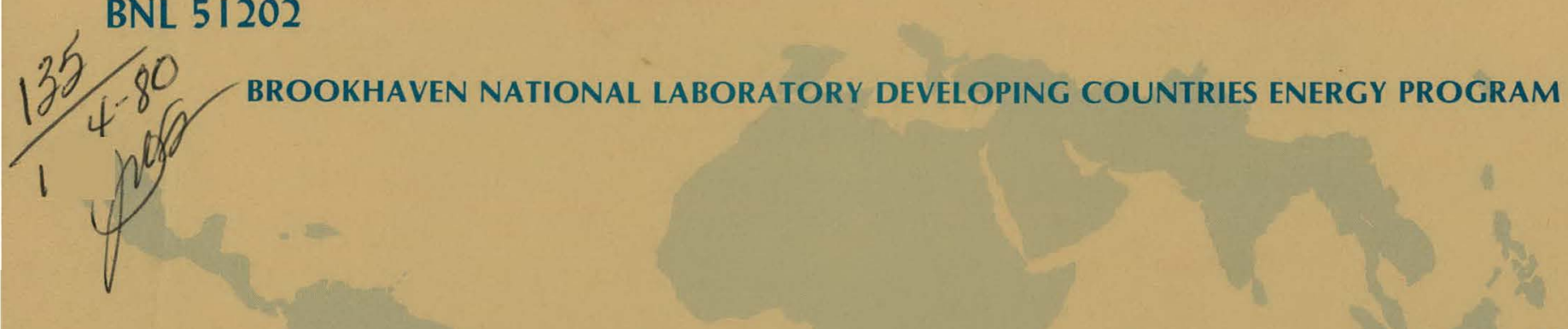

\title{
A PRELIMINARY ASSESSMENT OF ENERGY SUPPLY AND CONSUMPTION IN THE DOMINICAN REPUBLIC
}

Gordon McGranahan, Glen Mitchell,

Vinod Mubayi, and Robert Stern

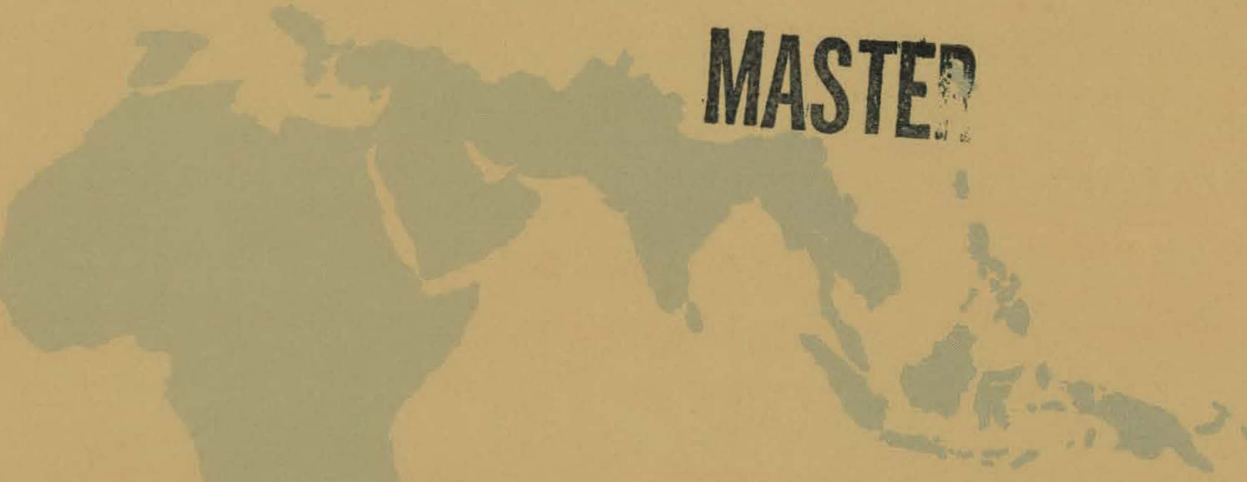

November 1979

DIVISION OF REGIONAL STUDIES

NATIONAL CENTER FOR ANALYSIS OF ENERGY SYSTEMS

BROOKHAVEN NATIONAL LABORATORY

UPTON, NEW YORK II973

prepared for

UNITED STATES AGENCY FOR INTERNATIONAL DEVELOPMENT

Under PASA No. ERDA/TAB-995-18-76 with the

U.S. Department of Energy 


\section{DISCLAIMER}

This report was prepared as an account of work sponsored by an agency of the United States Government. Neither the United States Government nor any agency Thereof, nor any of their employees, makes any warranty, express or implied, or assumes any legal liability or responsibility for the accuracy, completeness, or usefulness of any information, apparatus, product, or process disclosed, or represents that its use would not infringe privately owned rights. Reference herein to any specific commercial product, process, or service by trade name, trademark, manufacturer, or otherwise does not necessarily constitute or imply its endorsement, recommendation, or favoring by the United States Government or any agency thereof. The views and opinions of authors expressed herein do not necessarily state or reflect those of the United States Government or any agency thereof. 


\section{DISCLAIMER}

Portions of this document may be illegible in electronic image products. Images are produced from the best available original document. 
BNL 51202

UC-13

(General, Miscellaneous, and

Progress Reports - TIC-4500)

\title{
A PRELIMINARY ASSESSMENT OF ENERGY SUPPLY AND CONSUMPTION IN THE DOMINICAN REPUBLIC
}

\author{
Gordon Mcgranahan, Glen Mitchell, \\ VINOD MUBAYI, AND ROBERT STERN
}

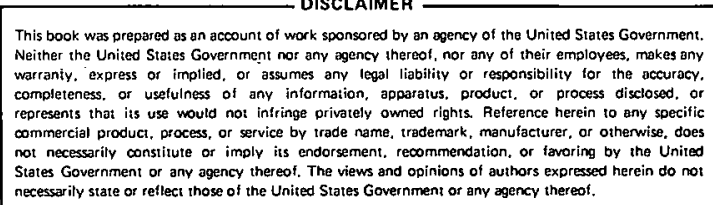

November 1979

DIVISION OF REGIONAL STUDIES

NATIONAL CENTER FOR ANALYSIS OF ENERGY SYSTEMS

BROOKHAVEN NATIONAL LABORATORY

UPTON, NEW YORK 11973

Prepared for

UNITED STATES AGENCY FOR INTERNATIONAL DEVELOPMENT

Under PASA No. ERDA/TAB-995-18-76

With the

U.S. DEPARTMENT OF ENERGY 


\section{DISLLLAMEK}

This book was prepared as an account of work sponsored by an agency of the United States Government. Neither the United States Government nor any agency thereof, nor any of their employees, makes any warranty, express or implied, or assumes any legal liability or responsibility for the accuracy, completeness, or usefulness of any information, apparatus, product, or process disclosed, or represents that its use would

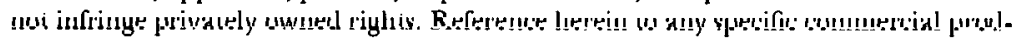
uct, process, or service by trade name, trademark, manufacturer, or otherwise, does not necessarily constitute or imply its endorsement, recommendation, or favoring by the United States Government or any agency thereof. The views and opinions of authors expressed herein do not necessarily state or reflect those of the United States Government or any agency thereof.

Printed in the United States of America

Available from

National Technical Information Service

U.S. Department of Commerce

5285 Port Royal Road

Springfield, VA 22161

Price: Printed Copy $\$ 600$; Microfiche $\$ 3 \div 0$

$$
\text { AO5 } 5 \text { AO }
$$




\section{TABLE OF CONTENTS}

Preface and Acknowl edgments.................................. vii

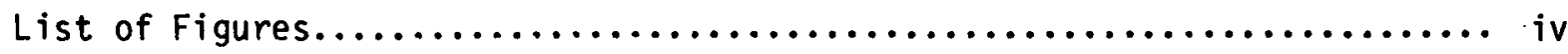

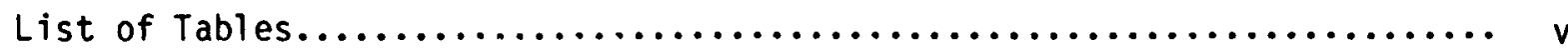

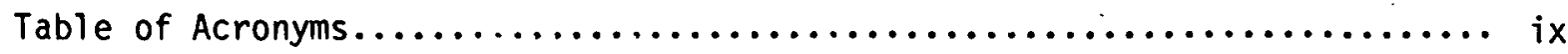

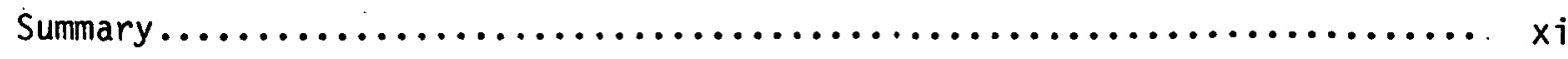

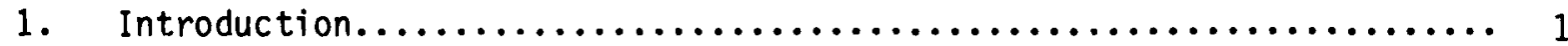

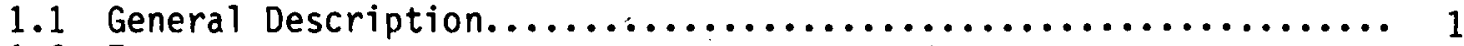

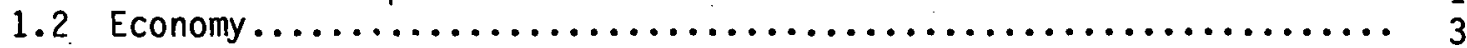

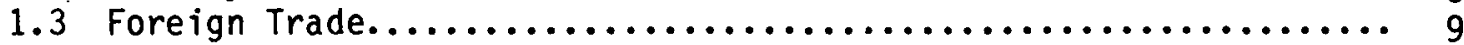

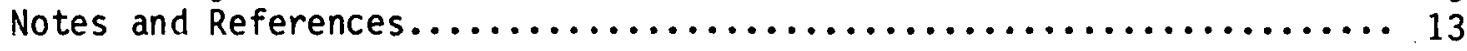

2. Energy Resources and Production........................... 17

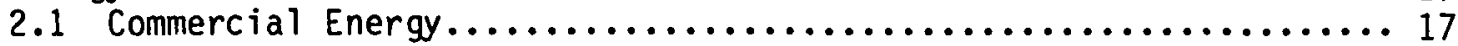

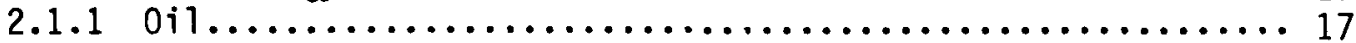

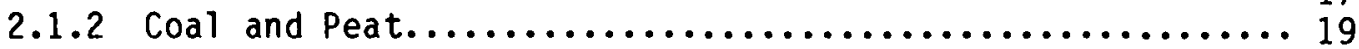

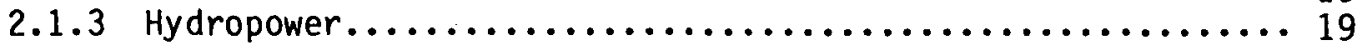

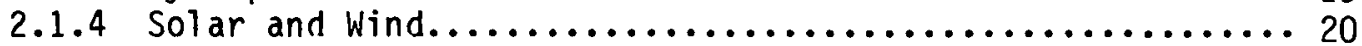

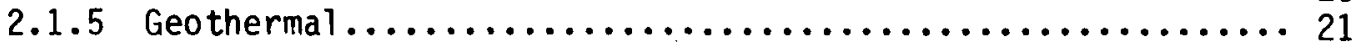

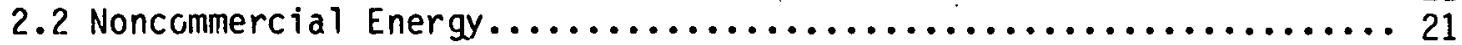

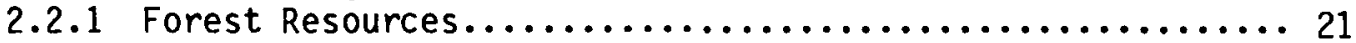

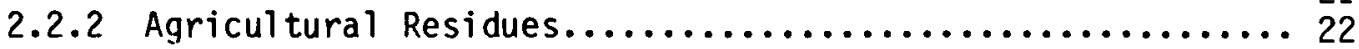

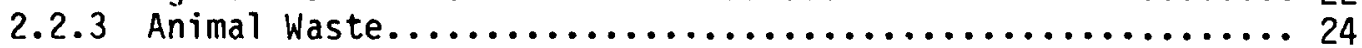

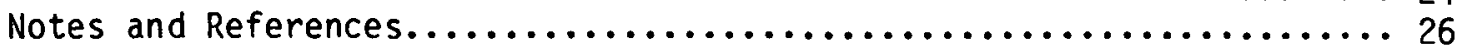

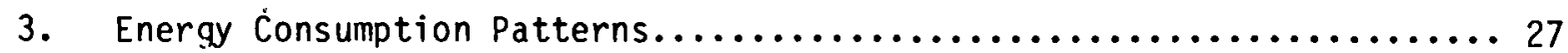

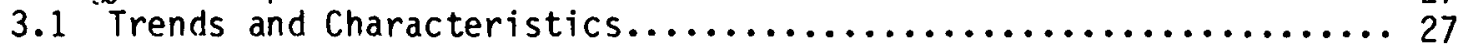

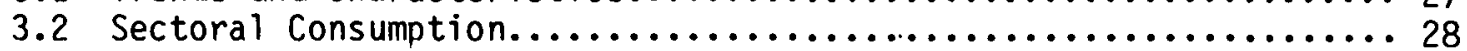

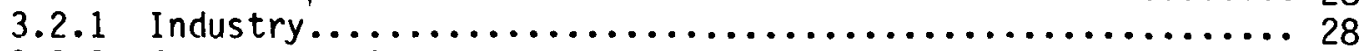

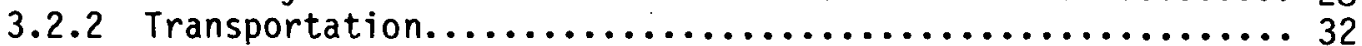

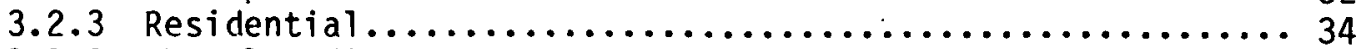

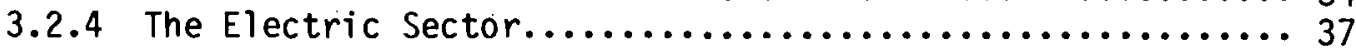

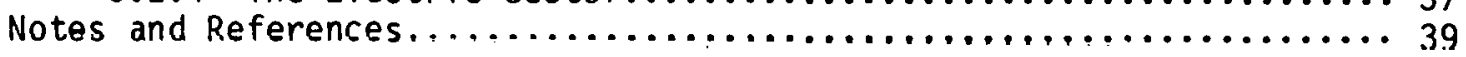

4. Future Energy Outlook............................. 41

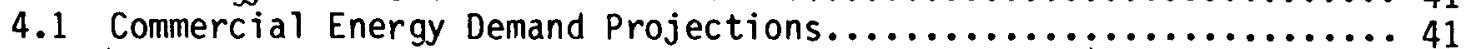

4.2 Noncommercial Energy Projections....................... 43

Notes and References.................................. 46

5. Observations and Conclusions......................... 47

Notes and References................................ 49

Appendix A: Reference Energy Systems...................... 50

Appendix B: Commercial Energy Projections Assumptions.............. 54

Appendix C: Dominican Republic Tentative Crop Profiles and Energy Input

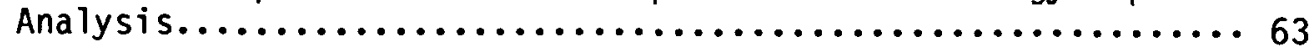

Appendix D: Energy Conversion Tables....................... 81 


\section{LIST OF FIGURES}

1 Map of Dominican Republic......................... 2

2 Dominican Republic Reference Energy System, $1977 \ldots \ldots \ldots \ldots \ldots \ldots . \ldots 1$

3 Dominican Republic Reference Energy System,

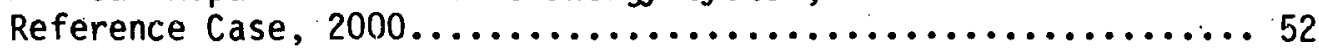

4 Dominican Republic Reference Energy System, Case 2, 2000...... 53 


\section{LIST OF TABLES}

1 Percentage Distribution of 1977 GDP at Constant 1970 Prices and Sectoral Growth Rates.......................... 4

2 Export Value of Selected Commodities, 1974-1977............ 5

3 Export Volume of Selected Commodities and Countries of Destination.................................. 6

4 Production of Selected Manufactured Products, $1973-1977 \ldots . \ldots . . .9$

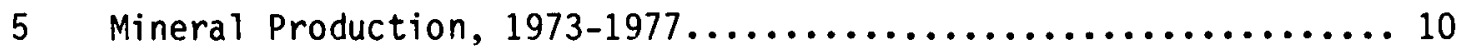

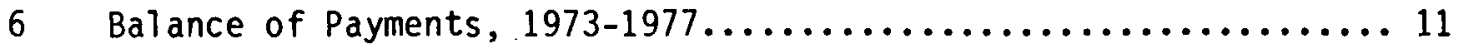

7 Imports of Petroleum and Petroleum Derivatives (RD\$),

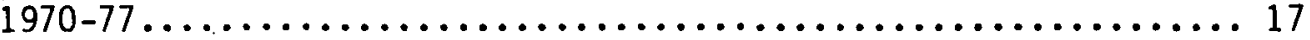

8 Imports of Petroleum and Petroleum Derivatives

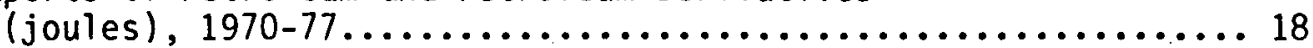

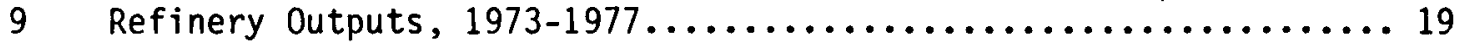

10 Hydro Capacity Expansion, Selected Years.................. 20

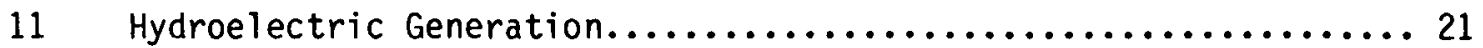

12 Sustainable Yield of Forested Area...................... 22

13 Wood Production, $1967,1970-77 \ldots \ldots \ldots \ldots \ldots \ldots \ldots \ldots \ldots \ldots \ldots \ldots$

14 Wood and Charcoal Resource Use, $1973-77 \ldots \ldots \ldots \ldots \ldots \ldots \ldots \ldots . \ldots 23$

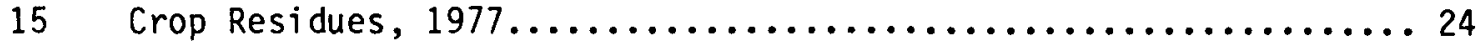

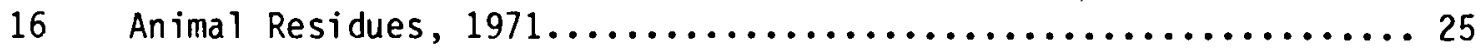

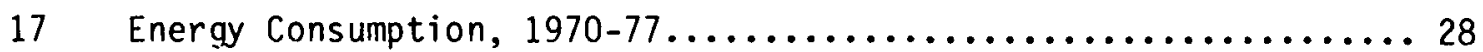

18 Energy Consumption by Sector and Resource, $1977 \ldots \ldots \ldots \ldots \ldots \ldots 29$

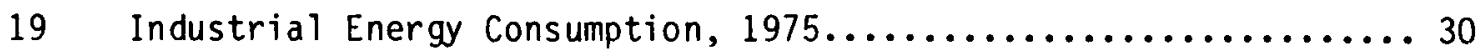

20 Production and Energy Consumption Data for

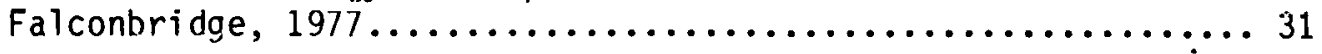

21 Transportation Fuel Consumption by Vehicle Type............. 33

22 Number of Registered Motor Vehicles, 1972-77.............. 33

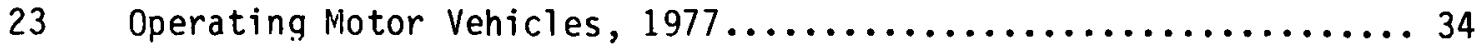




\section{LIST OF TABLES (continued)}

24. Fuels Used for Urban and Rural Residential Cooking........... 35

25 Fuels Used for Lighting in Urban and Rural Households......... 36

26 Electricity Use in Urban and Rural Households.............. 36

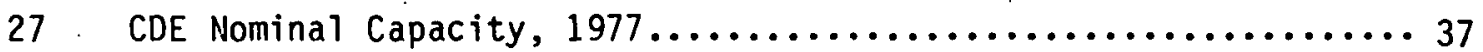

28 CDE Electricity Generation (on line), Purchases

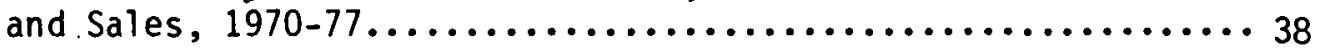

29 Commercial Energy Demand, $1977 \ldots \ldots \ldots \ldots \ldots \ldots \ldots \ldots \ldots \ldots \ldots \ldots \ldots$

30 Commercial Énergy Demand Projection - Reference Case......... 43

31 Commercial Energy Demand Projection - Case $2 \ldots \ldots \ldots \ldots \ldots \ldots \ldots . \ldots 4$

32 Commercial Energy Demand Projections Assumptions........... 54

33 Assumptions for Reference Case Sectoral Breakdown of Commercial Energy Demand........................... 55

34 Fuel Mix Tables, Urban Cooking; 1977, 1990, 2000........... 57

35 Fuel Mix Table, Rural Cooking; 1977, 1990, 2000............. 58

36 Fuel Mix Table, Urban Lighting; 1977, 1990, 2000........... 59

37 Fuel Mix Table, Rural Lighting; 1977, 1990, 2000........... 60

38 Fuel Mix Table, Urban Appliances; $1977,1990,2000 . \ldots \ldots \ldots . \ldots . ., 61$

39 Fuel Mix Table, Rural Appliances; $1977,1990,2000 \ldots \ldots \ldots \ldots \ldots 62$ 
Recent events affecting the cost and availability of energy have focused attention on the need to understand in greater detail how energy is used, directly and indirectly, in the agricultural and food systems of developing countries. This energy overview of the Dominican Republic, initiated and sponsored by the U.S. Agency for International Development (USAID), attempts to meet that need by providing not only an analytical base for evaluating initiatives that are likely to be applicable to many developing countries but also an improved basis from which U.S. assistance policy can be made.

The authors profited immensely. from the comments of Charles Blankstein (U.S. Aid Mission to the DR) and were assisted greatly by the help of Manuel Canario and Joaquim Santaella (INDOTEC), Jose Ramon Acosta (Dominican Republic Energy Commission), and Gerhard Tschannerl (Consultant to BNL). The authors of the report are solely responsible for its content, however.

The preparation of the report was carried out by Patricia Miller. 
THIS PAGE

\section{WAS INTENTIONALLY LEFT BLANK}


TABLE OF ACRONYMS

BA - Agrarian Bank

CALA - Commission for the Application of Agrarian Laws

CAT - Tax Payment Certificate

CDE - Electricity Corporation of Dominica

CEA - State Sugar Council

CEDOPEX - The Dominican Center for the Promotion of Exports

CENDA - National Agricultural Development Center

CFI - Industrial Development Corporation

CNIECA - The Center for Agricultural Research and Extension

CORDE - State Enterprises Corporation

CODIA - Dominican College of Engineers, Architects and Surveyors

CRIES/SIEDRA - Comprehensive. Resource Inventory and Evaluation System of Agriculture

DCV - Rural Road Directorate

FAD - Food and Agricultural Organization (United Nations)

FIDE - Economic Development Investment Fund

IAD - Dominican Agrarian Institute

IDB - Inter-American Development Bank

IDECOOP - Institute of Development and Cooperative Credit

IDSS - Dominican Social Security Institute

INAZUCAR - National Sugar Institute

INCAP - Institute of Nutrition for Central America and Panama

INDRHI - National Water Resourçes Institute

INESPRE - Price Stabilization Institute

IICA - Inter-American Institute of Agricultural Sciences

ONAPLAN - National Planning Office

ONAPRES - National Budget office 
TABLE OF ACRONYMS (continued)

$\begin{array}{ll}\text { PCI - } & \text { Practical Concepts Incorporated } \\ \text { RPUS - } & \text { Resource Production Units } \\ \text { SEA - } & \text { Secretariat of Agriculture } \\ \text { UNDP - } & \text { United Nations Development Programe }\end{array}$


This report presents a preliminary description of the Dominican Republic's energy resources, its recent energy supply-demand pattern, and some energy demand projections for the years 1990 and 2000.

- Of approximately 129 quadrillion joules of energy consumed in 1977, 66 percent was attributable to commercial fuels. 0il is the most important energy source, accounting for about 64 percent of the country's total energy consumption in recent years.

- Total energy consumption grew at an average annual rate of 8 percent between 1970 and 1977. During the same period, per capita energy consumption increased from 18.5 billion joules to 25.9 billion joules (about 5 percent per year).

- Industry is the largest energy consumer, accounting for about 46 percent of total energy consumption in 1977. Public Utilities accounted for another 19 percent, followed by the residential sector with 18.6 percent and transportation with 14.3 percent.

- In the absence of any domestic production, the Dominican Republic has had to rely on imports to satisfy all of its oil requirements. Between 1971 and 1974 the value of imports of petroleum and petroleum products increased sixfold. However, with the installation of the Haina refinery (11 million barrel capacity), the composition of petroleum imports has changed significantly; with the exception of fuel oil, refinery production has displaced most of the petroleumbased fuel imports.

- The Dominican Republic is not very well endowed with energy resources. There is some indication that oil and geothermal resources exist, but it appears unlikely that they will contribute significantly to the national energy system, at least in the near future. With respect to the country's hydro potential, fifty sites, as of 1976, had been identified with a total capacity of approximately 1 $\mathrm{GW}_{\mathrm{e}}$ and an electricity generation capability of 2,500 GWh per annum. Noncommercial energy resources such as bagasse, wood, and charcoal are relatively abundant hut a great portion of the accessible forest lands has been depleted. Although the level of solar radiation is relatively high, it is a virtually untapped energy source. Under current conditions wind energy does not appear to be significant except in isolated locations.

- To provide a "Reference Case," commercial energy demand is projected without explicit consideration of the effect of rising energy prices. With a GDP growth rate of 6 percent per annum, commercial energy demand is projected to grow to $228.1 \times 10^{15}$ joules in 1990 and $486.5 \times 1015$ joules in 2000 . The sectoral composition of commercial energy demand in 2000 is 40 percent industrial, 34 percent public sector electricity generation and transmission (net of sales), 19 percent transportation, 5 percent residential, and 4 percent other uses. $0 i 1$ alone is projected to account for about 95 
percent of commercial resource use in the year 2000 (the remainder being hydrol.

- A second case, incorporating a price elasticity of 0.3 for commercial energy demand and an annual growth rate of real energy prices of 4 percent per annum, projects commercial energy demand to grow to $195.7 \times 10^{15}$ joules in 1990 and $371.2 \times 10^{15}$ joules in 2000 . The share of $0 i 1$ in total resource use in the year 2000 is 94 percent.

- Two of the major noncommercial fuels, wood and charcoal, are projected to supply about $20,7 \times 1015$ joules of fuel energy in the year 2000 of which $16.7 \times 10^{15}$ joules are destined to rural cooking. Bagasse is projected to supply 59 to $75 \times 10^{15}$ joules, while other crop residues and animal waste could potentially supply an additional $16.3 \times 10^{15}$ joules and $113 \times 10^{15}$ joules respectively. (The potential role of noncommercial fuels in the energy system is smaller than these figures may imply because of the low end-use efficiencies and collection problems.) 


\section{INTRODUCTION}

\subsection{GENERAL DESCRIPTION}

The Dominican Republic, the second largest Caribbean country with a land area of 48,734 square kilometers* (about the size of Maryland and New Hampshire combined), occupies the eastern two-thirds of the island of Hispaniola. It is bordered on the north by the Atlantic Ocean, on the east by the Mona Passage which separates it from Puerto Rico, on the south by the Caribbean Sea, and on the west by Haiti.

With an estimated population of 4.98 million in 1977,1 the Dominican Republic (DR) is the fourth most populous country in Central America. 2 The average annual population growth rate is relatively high at about 2.9 percent from 1970-76.3 The rural-urban split is fairly even with about 46 percent ${ }^{4}$ of the population living in urban areas mostly in and around the big cities of Santo Domingo in the central region and Santiago in the north. Between 1960 and 1975 the population of these two cities grew at an average annual rate of more than 6 percent. 5 The rate of population increase for other urban areas over the same period ranged from 3.8 percent in Mao to 7 percent in San Pedro de Marcoris. 6

The Cordillera Central and three other parallel mountain ranges (Cordillera Septentrional, Sierra de Neiba, Sierra de Baoruco), all running in a northwesterly direction, dominate the highland topography ${ }^{\prime}$ in the western part of the country, while the Cordillera Oriental, a narrow band of hills and somewhat less imposing, is the principal mountain system in the east. Running some 200 kilometers across the republic with its rugged slopes, convoluted ridges, and extensive pine forests, the Cordillera Central virtually divides the country into two parts. Its highest peak, Pico Duarte, is the tallesi iii the West Indies rising to some 3,175 meters above sea level.

The Cordillera Septentrional which lies north of the Cordillera Central is a much smaller mountain range characterized by precipitous slopes and deeply etched valleys. Rising in the west near the town of Montecriste and extending as far east as the swamps surrounding the mouth of the Yuna River near the Samana. Peninsula, its highest point of elevation measures some 1219 meters.

The Sierra de Neiba and the Sierra de Baoruco both lie south of the Cordillera Central. Rising in the southwest near the Caribbean Sea, they both extend northwestward into Haiti where they join related ranges. Both have peaks as high as 1829 meters and crest generally at elevations of between 915 and 1220 meters.

Like the highlands which define them, the country's lowlands (the Cibao Valley, the San Juan Valley, and the Neiba Valley) stretch in a parallel northwesterly direction from origins close to the Caribbean to adjoining valleys in Haiti. The most famous of the lowland areas, the Cibao Valley, is the breadbasket of the country. Situated between the Cordillera Septentrional and the Cordillera Central, the Cibao covers some 5180 square kilometers

\footnotetext{
*Including 119 square kilometers of adjacent islands (Beata, Catalina, Saona, Al to Velo, Catalinita) in the Caribbean Sea.
} 


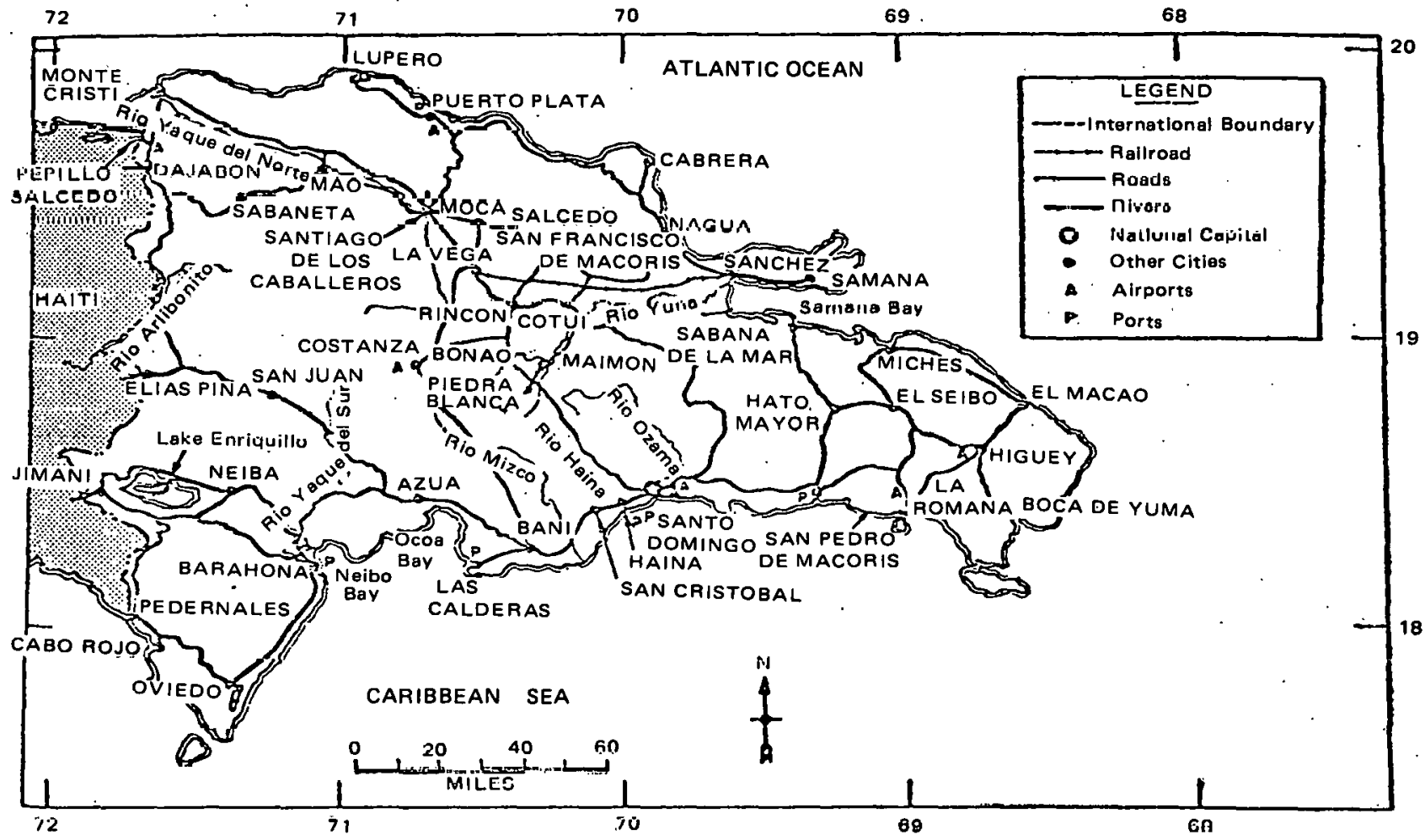

Source: Area Handbook for the Dominican Republic, U.S. Government Printing office, Washington, D.C, 1973.

Pigure 1. Map of Dominican Republic 
(about 10 percent of the national territory) from Samana Bay in the east to the Haitian border in the west. This is where population density is greatest. The Eastern Cibao Valley (known as the Vega Real or the Royal Plain), for example, especially the region between the cities of Santiago and San Pedro de Marcoris, is estimated to have densities exceeding 240 persons per square kilometer.

The San Juan Valley which is located between the Cordillera Central and the Sierra de Neiba covers an area of some 1820 square kilometers. Most of the people in this region are engaged in cattle raising and in rice, bean, and coffee production.

The other parallel valley, the Neiba (known also as the Enriquillo Basin), lies north of the Sierra de Baoruco. This is a low-lying plain occupying some 1950 square kilometers of semiarid land mostly in the area known as the Cul de Sac of Haiti. Its most distinctive landmark is the large salt lake, Lago Enriquillo, which is 44 meters below sea level and is considered the lowest lake in the West Indies.

The other major lowland area, the Caribbean Coastal Plain, is located in the eastern part of the country near the foothills of the Cordillera Oriental. The primary activities in this region which covers more than 2860 square kilometers are cattle raising and sugar production.

\subsection{ECONOMY}

The International Monetary Fund (IMF) estimates the Dominican Republic's (DR) GNP at $\$ 4.34$ billion and GNP per capita at $\$ 872$ in 1977.8 In the same year GDP was estimated at RD $\$ 4.46$ billion at current prices* and RD $\$ 2.54$ billion ${ }^{9}$ at 1970 consiant market prices. The sectoral composition of the cor and the 1973-77 growth rates of the individual sectors are shown in Table 1.

The agricultural sector in the DR is comprised mainly of those activities having to do with the production of food crops. Activities having to do with livestock production, fishing, and forestry are not viewed by the authorities as part of the agricultural sector as is the case in some other developing countries but as activities for separate sectors of the economy.

The agricultural sector which has grown at an average annual rate of 0.7 percent during the period 1973-77 produces two main types of crop - those principally for exportation and those principally for domestic consumption. Cane sugar, tobacco, coffee and cocoa are the main export crops while rice, corn, peanut, red beans, cassava, plantain, and tomatoes are some of the more important ones consumed locally.

of all agricultural crops, sugar is and has been the most important, not only in terms of tts contribution to employment and to GDPlO but al so in terms of export income. It led all other commodities in volume of exports in 1977 and was by far the top earner of foreign exchange in that same year. More than 1.1 million tons of sugar valued at $\$ 218.3$ millionll were exported representing an average annual growth rate of 11.1 percent from 1970 . Over the same period which saw very high world market prices in 1974-75 and extremely

\footnotetext{
*The rate of exchange was U.S. $\$ 1.00=R D \$ 1.00(1$ Peso $)$.
} 
TABLE 1

DOMINICAN REPUBLIC

PERCENTAGE DISTRIBUTION OF $1977^{P}$ GDP AT CONSTANT 1970 PRICES AND SECTORAL GROWTH RATES

\begin{tabular}{lcc}
\hline Sector & Percent & $\begin{array}{c}\text { Average } \\
\text { Annual Growth Rate, } \% \\
1973-1977\end{array}$ \\
\hline Agriculture & 11.3 & 0.7 \\
Livestock & 5.4 & 3.5 \\
Forestry/Fishing & 0.4 & 4.2 \\
Mining & 5.6 & 9.2 \\
Manufacturing & 18.4 & 5.3 \\
Construction & 7.2 & 7.4 \\
Curiulerce & 16.7 & 5.7 \\
Transport & 7.3 & 7.0 \\
Communications & 1.0 & 12.4 \\
Electricity & 1.5 & 10.6 \\
Money and Banking & 2.3 & 15.2 \\
Ownership of Dwellings & 6.7 & 7.2 \\
Government Services & 7.4 & 4.5 \\
Other Services & 8.8 & 5.4 \\
Gross Domestic Product 100.0 & 5.5 \\
GDP per capita & - & 2.4 \\
\hline P preliminary figures. & & \\
SourCE: Reference 9, pp. 181-183. & \\
\hline
\end{tabular}

low ones in 1976 and 1977, the volume of exports grew at an average annual rate of 5.3 percent.

Since its introduction into the $D R$ in the early part of the eighteenth century, coffee has become one of the more important crops. * of the 120,416 tons 12 produced in 1977 , mostly on small farms in Barahona, the Cibao valley, and the 0coa River region, more than 79,000 tons valued at $\$ 169.5$ millition were exported which is more than twice the 1976 export volume and almost a threefold increase since 1970.13

Although the volume of cocoa exports increased by only 4 percent from 1976 to 1977, the value of exports increased more than 209 percent during the same period. Export volume amounted to 24,612 tons in 1976 and only 25,615 in 1977 while the value of exports jumped from RD $\$ 43.37$ million to RD $\$ 93.06$

*Almost all of DR's coffee is of the "arabica" variety, the world's most popular type. Some coffee of the "robusta" type is produced but not in any significant quantities. 
million.14 This no doubt was a reflection of the dramatic increase in cocoa prices; for example, the price of cocoa went from U.S. $\$ 65.75$ (fob) per 100 pounds on the New York market in January 1976 to U.S. $\$ 209.3$ in July 1977.15 The DR is not a signatory to the International Cocoa Agreement of 1975 although it is one of the major producing countries 16 ; therefore it is not restricted by price and quota regulations under the agreement.

of all the main export crops, tobacco has been the most seriously affected by fluctuations in foreign demand. In addition, the outmoded techniques used in its production and the marked inequalities surrounding the distribution of its profits have, at least in some sections of the country, contributed greatly to the steady decline of the crop.17 In 1960,15,193 tons of tobacco valued at RD $\$ 6.73$ million were exported. By the end of the next decade export volume had reached only 19,535 tons. Although export volume increased sharply in 1975 (37,137 tons) and 1976 (32,798 tons), most of the 1970 's saw relatively low levels of exports. In 1977, for example, only 18,686 tons reached foreign markets, mostly Spain (62 percent), United States ( 9 percent), Belgium-Luxembourg ( 6 percent), and Holland ( 5 percent).18 Tables 2 and 3 show main export commodities for 1974-77, their value, volume, and country of destination.

Because the DR is a deficit-producer of basic foodstuffs it needs, the authorities* must import in order to meet internal demand. 19 The reduction of imports via domestically produced substitutes is therefore an understandable policy goal of the government 20 and a clear indication of the importance of those crops that are produced primarily for local consumption. 21

Rice is the most important staple not necessarily because of its nutritional value but mainly because it is the food most preferred by

TABLE 2

DOMINICAN REPUBLIC

EXPORT VALUE OF SELECTED COMMODITIES, 1974-1977 (Millions of RD \$)

\begin{tabular}{lrrrr}
\hline Commodities & \multicolumn{1}{c}{1974} & \multicolumn{1}{c}{1975} & \multicolumn{1}{c}{1976} & \multicolumn{1}{c}{1977} \\
\hline Sugar & 324.12 & 552.13 & 247.09 & 218.32 \\
Coffee & 39.29 & 34.70 & 83.30 & 169.54 \\
Cocoa & 44.23 & 24.77 & 44.37 & 93.06 \\
Tobacco & 39.00 & 34.40 & 38.26 & 27.12 \\
Ferronickel & 93.09 & 102.14 & 110.33 & 91.92 \\
Bauxite & 17.75 & 16.72 & 15.52 & 21.98
\end{tabular}

Source: Data (market value) for 1974 from Reference 9, pp. 109-112. Data (fob value) for 1975-1977 from Reference 11, pp. 17-19.

*The Price Stabilization Institute of Instituto de Establizacion de Precios (INESPRE) is responsible for most of the government's import activities, and as of March 1976, supported the prices of eight crops - rice, red and black beans, corn, sorghum, coconut, copra, garlic, and onion. 
TABLE 3

DOMINICAN REPUBLIC

EXPORT VOLLME OF SELECTED COMMODITIES AND COUNTRIES OF DESTINATION

\begin{tabular}{|c|c|c|c|c|c|c|c|c|}
\hline \multirow[b]{2}{*}{$\begin{array}{l}\text { Commodity and } \\
\text { Country }\end{array}$} & \multicolumn{2}{|l|}{$1974^{C}$} & \multicolumn{2}{|c|}{1975} & \multicolumn{2}{|c|}{1976} & \multicolumn{2}{|c|}{1977} \\
\hline & $\begin{array}{l}\text { Volume } \\
\text { (metric } \\
\text { tons) }\end{array}$ & $\%$ & $\begin{array}{l}\text { Volume } \\
\text { (metric } \\
\text { tons) }\end{array}$ & $\%$ & $\begin{array}{l}\text { Volume } \\
\text { (metric } \\
\text { tons) }\end{array}$ & $\%$ & $\begin{array}{l}\text { Volume } \\
\text { (metric } \\
\text { tons) }\end{array}$ & $\%$ \\
\hline Sugara & $1,015,744$ & 100.0 & 938,785 & 100.0 & 963,270 & 100.0 & $1,101,040$ & 100.0 \\
\hline United States & $718,2.81$ & 70.7 & 684,648 & 72.9 & 895,083 & 92.9 & 881,331 & 80.0 \\
\hline Italy & - & - & 54,975 & 5.8 & - & - & - & - \\
\hline Romania & - & - & 31,992 & 2.4 & 8,205 & 0.8 & - & - \\
\hline Kenya & $=$ & - & - & - & 14,980 & 1.5 & - & - \\
\hline Morocco & - & - & 29,965 & 3.1 & - & - & 63,236 & 5.7 \\
\hline Coffeea & 31,137 & 100.0 & 25,642 & 100.0 & 35,248 & 100.0 & 79,751 & 100.0 \\
\hline $\begin{array}{l}\text { United States } \\
\text { Belgium-Luxembourg } \\
\text { Puerto Rico }\end{array}$ & $\begin{array}{c}25,563 \\
1,148 \\
-\end{array}$ & $\begin{array}{l}82.0 \\
3.6 \\
-\end{array}$ & $\begin{array}{c}21,980 \\
1,337 \\
-\end{array}$ & $\begin{array}{c}85.7 \\
5.2 \\
-\end{array}$ & $\begin{array}{r}31,851 \\
796 \\
967\end{array}$ & $\begin{array}{r}90.3 \\
2.2 \\
2.7\end{array}$ & $\begin{array}{r}76,281 \\
458 \\
2,113\end{array}$ & $\begin{array}{r}95.6 \\
0.5 \\
2.6\end{array}$ \\
\hline Cocoad & $\underline{26,560}$ & $\underline{100.0}$ & 21,668 & 100.0 & $\underline{24,612}$ & 100.0 & 25,615 & 100.0 \\
\hline United States & 26,126 & 98.3 & 21,507 & 99.2 & 24,612 & 100.0 & 25,201 & 98.3 \\
\hline Ferronickela & $\underline{79,839}$ & 100.0 & $\underline{63,066}$ & 100.0 & 68,139 & 100.0 & 59.947 & 100.0 \\
\hline Holl and & 36,907 & 46.2 & 36,585 & 58.0 & 28,847 & 42.3 & 27,084 & 45.1 \\
\hline United States & 38,236 & 47.8 & 17,062 & 27.0 & 26,050 & 38.2 & 27,453 & 45.7 \\
\hline Cariada & $=$ & - & 4,524 & $\overline{7} .1$ & 11,346 & 16.6 & - & - \\
\hline Bauxite & $1,473,588$ & 100.0 & $\underline{909,906}$ & $\underline{100.0}$ & 627,152 & 100.0 & 774,098 & 100.0 \\
\hline & & & & & & & & \\
\hline United States & $1,473,588$ & 100.0 & 909,906 & 100.0 & 627,152 & 100.0 & 774,098 & 100.0 \\
\hline Tobaccoa & $\underline{42,326}$ & 100.0 & 37,137 & 100.0 & 32,798 & 100.0 & 18,686 & 100.0 \\
\hline $\begin{array}{l}\text { Spain } \\
\text { United States }\end{array}$ & $\begin{array}{r}22,398 \\
4,347\end{array}$ & $\begin{array}{l}52.9 \\
10.2\end{array}$ & $\begin{array}{r}15,855 \\
4,315\end{array}$ & $\begin{array}{l}42.6 \\
11.6\end{array}$ & $\begin{array}{r}19,421 \\
3,351\end{array}$ & $\begin{array}{l}59.2 \\
10.2\end{array}$ & $\begin{array}{r}11,731 \\
1,689\end{array}$ & $\begin{array}{r}62.7 \\
9.0\end{array}$ \\
\hline $\begin{array}{l}\text { aData from Reference } \\
\text { bData from Reference } \\
\text { cData from Boletin Me }\end{array}$ & $\begin{array}{l}\text { pp. } 17 \\
\text { p. } 115\end{array}$ & 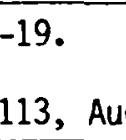 & . & & & & & \\
\hline
\end{tabular}


Dominicans, especially those in the rural areas.22 The importance of rice is even more evident when one looks at the number and value of loans made to the rice subsector by the Dominican Development Bank in 1975.23 From January to September, 51 loans amounting to RD $\$ 543,337$ were made to rice projects; this represented 23.3 percent of the number and 28.16 percent of the value of all loans made during the period. Despite the disastrous drought which affected not only rice but all other crops that year, 24 output of rice reached almost 290,000 tons in 1977, an increase of 11 percent from 1974 and almost 33 percent from 1975.25 This, however, was not sufficient to meet domestic demand and INESPRE was forced to import more than 56,000 tons at a cost of RD $\$ 17.04$ million ( fob). 26

With respect to intake (grams) of the various foods, plantain leads the field in both urban and rural areas. An unpublished 1973 consumption survey by the Secretariat of Agriculture indicated that urban and rural per capita daily intake of plantains was 192 and 182 grams respectively, compared to the figures of 160 (urban) and 174 grams (rural) for rice. An earlier survey had also indicated the dominance (intake) of plantains in the Dominican diet. 27

Nutritionally, beans, especially kidney beans which are the most commonly grown variety, are of great importance to the rural population. Among the common foods, they rank first as the available source for proteins and iron, second for calcium and thiamine, and third for riboflavin.28 Kidney beans production was about 40,264 tons in 1977, a 10.6 percent drop from the 1976 figure and an 18.3 percent decline from the bumper year 1974.29 This required imports totaling 4,872 tons in 1977 in order to satisfy internal demand; consumption in that same year amounted to 43,624 tons.

As a result of expansion in the livestock industry over recent years, corn has become increasingly more important. Frequently interplanted $w$ ith other crops, especially beans, it is by far the primary feed* utilized in animal production. In 1977, corn production was only 54,152 tons $(967,000$ quintales) - the first time since 1973 that output amounted to less than 56,000 tons (1 million quintales). 30 While human consumption of corn since 1973 has remained relatively constant, in absolute terms, imports of corn along with animal consumption of the crop have been steadily increasing. Human consumption of corn ranged from 7,224 tons in 1973 to 8,344 tons in 1977 while the corresponding figures for animal consumption were 113,288 and 129,920 tons; and for imports $-66,976$ tons in 1.973 and 92,400 tons in 1977.31

Cassava (yuca) is the major root crop in the Dominican diet, especially for lower income families. Of the 183,680 tons produced in 1977, almost 172,660 tons (94 percent) were consumed locally by humans, 7,347 tons ( 4 percent) by animals, and only about 2 percent were exported. 32

Table (salad) as well as industrial tomatoes are grown in the Dominican Republic mostly on farms that are less than 3 hectares in size and on which relatively high levels of capital intensive techniques are used. About 134,814 tons 33 of tomatoes were produced in 1977 , most of which were industrial tomatoes - some 118,462 tons. 34

*In addition to corn, sweet potato, sorghum, and cassava are used to feed animals; in each year from 1973-1977, no more than 5.8 percent of the yearly corn supply has ever been consumed by humans; see Reference 29. 
Among the oilseeds, * peanut is the most important not only in terms of its prevalence in the Dominican diet 35 but also because of the income it generates for some small farmers; about 48,000 tons of peanut (in shell) were produced in 1977 representing an increase of 10.2 percent over 1976 but a decline of more than 19 percent from the 1974 figure. 36 Peanut oil imports decreased steadily over the period 1973-75 but rose sharply in 1976 and 1977.37

The forestry/fishing sector share in GDP went from 0.6 percent in 1973 to 0.4 percent in 1977.38 Although this is a relatively small decline, it indicates, nevertheless, that the sector has not kept pace with the demands of a rising population. There are two primary reasons for this state of affairs in the forestry/fishing sector. Since the modification of the forestry law (No. 206) in 1967, limiting timber cutting rights in order to prevent further deterioration of forest lands, 39 output of timber and wood products has declined as much as 29 percent (1969) and by 1977 was still 3.6 percent less than the 1968 output figures. 40 The other main reason is that fishing methods as now practiced in the DR are primitive and inefficient; for example, the boat (known as the "yola") used by most fishermen is slow, cannot navigate well in relatively rough waters, and does not have facilities for preserving (ice or brine) either the catch or storing additional fuel supplies. As a result, most fishing activities take place in inshore waters and consequently deplete those areas of formerly common fish varieties.

Although the DR is still in the very early stages of industrialization, the production of manufactured goods has been growing at a healthy rate. The manufacturing sector grew at an average annual rate of 5.3 percent from 1.973 to 1977; this compares favorably with the growth rates of the agriculture, forestry/fishing, and livestock sectors but less so with the mining, construction, electric, and transpertation sectors. 41 The 1977 production estimates for the chemical industry indicate that of the industry's five main products only two fell below their 1976 output figures; furfural declined from 34,226 tons in 1976 to 30,249 tons in 1977 and output of paints drnpped from 6,806 liters to 5,904 liters; on the other hand, chemical fertilizers increased from 176,539 tons to 183,057 tons, urethane foam from $11.60 \times 10^{6} \mathrm{ft}^{2}$ to $13.24 \times$ $10^{6} \mathrm{ft}^{2}$, and soap from 25,841 tons to 28,378 tons. 42 The two-plant cement industry produced some 862,126 tons of cement in 1977 representing an increase of almost 32 percent from 1976,43 and the value of textiles produced increased from $R D \$ 27.9$ million to RD $\$ 29.5$ million (1970 prices) during the same period. 44 Table 4 shows output of selected manufactured products from 1973 to 1977.

of the wide variety of mineral resources in the DR, nickel is by far the most important; exported as ferronickel since 1974, only sugar, coffee, and cocoa surpassed it as earner of foreign exchange in 1977. Prior to 1972 when

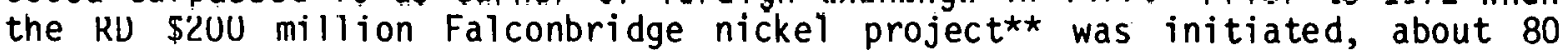

*Coconut (copra), cotton, and soya are the other well-known oil crops.

**The Falconbridge Dominicana Company which is jointly owned by the government and two foreign firms (Canadian, U.S.) was responsible for the RD $\$ 200$ million initial financing. To date, this has been the largest single investment project in the DR's history. 
TABLE 4

DOMINICAN REPUBLIC

PRODUCTION OF SELECTED MANUFACTURED PRODUCTS, 1973-1977

\begin{tabular}{lcccccc}
\hline Year & $\begin{array}{c}\text { Furfural } \\
\text { (tons) }\end{array}$ & $\begin{array}{c}\text { Paint } \\
\text { (1iters) }\end{array}$ & $\begin{array}{c}\text { Fertilizer } \\
\text { (tons) }\end{array}$ & $\begin{array}{c}\text { Urethane } \\
\text { Foam } \\
\text { (ft }{ }^{2} \text { ) }\end{array}$ & $\begin{array}{c}\text { Soap } \\
\text { (tons) }\end{array}$ & $\begin{array}{c}\text { Cement } \\
\text { (tons) }\end{array}$ \\
\hline 1973 & 26.970 & 4.964 & 184.084 & 4.632 & 22,810 & 581.925 \\
1974 & 24,021 & 4.640 & 164.365 & 5,445 & 21,848 & 642,518 \\
1975 & 35,660 & 5,165 & 143,929 & 6,666 & 22,862 & 554,931 \\
1976 & 34,226 & 6,806 & 176,539 & 11,604 & 25,841 & $653,8777^{\star}$ \\
$1977^{\star}$ & 30,249 & 5,904 & 183,057 & 13,246 & 28,378 & 862,126
\end{tabular}

*Preliminary figures.

Source: Reference 12, pp. 50-51.

percent of all mining activities were confined to the extraction of bauxite and about 20 percent to 1 imestone, gypsum, salt, and building stones. Since the completion of the extracting and processing facility near the town of Banao, however, nickel has replaced bauxite as the primary mining industry. Table 5 shows production of some selected minerals from 1973 to 1977.

\subsection{FOREIGN. TRADE}

Among Caribbean countries, the Dominican Republic is one of the most active in international trade. In 1977, about 66 percent of all its exports (market value) went to the United States, 7 percent to both Portugal and Puerto Rico, 2 percent to both Spain and Morocco, 1.6 percent to both Venezue$1 \mathrm{a}$ and Belgium-Luxembourg and anywhere from .2 to 5 percent each to Italy, Haiti, and Japan. 45 With the exception of Morocco, all these countries, especially the United States, Venezuela, and Puerto Rico, provided the bulk of the DR's imports for that same year. $46^{\circ}$ In 1975, the DR ranked first as supplier to the United States for sugar, fourth for cocoa, and fifth for bauxite. 47 Sugar accounted for 28 percent of the value of exports in 1977 (down 7.5 percent from the previous year), followed by coffee with 20.4 percent (down 8 percent from 1976), cocoa with 12 percent (down almost 6 percent), ferronickel with 11.6 percent (a decline of about 3 percent), and gold and silver alloys with 7 percent (up .6 percent during the same period). 48 The balance of payments figures, however, provide a better view of the performance of the economy as a whole.

For five of the eight years between 1969 and 1977 the DR ran a trade deficit. After the trade deficit had increased from RD $\$ 64$ million in 1970 to RD $\$ 69$ million in 1971 , the following two years (1972 and 1973) saw surpluses of RD $\$ 9.98$ million and RD $\$ 20.26$ million, respectively; by 1974 , the country again experienced a negative trade balance ( $R D \$ 36.19$ million) but recovered in 1975 with a surplus of RD $\$ 121.16$ million. Since then the country has been running a deficit each year, reaching some RD $\$ 66.98$ million in 1977 and RD $\$ 184.2$ million in 1978.49 The overall balance of payments, on the other hand, 


\section{TABLE 5}

DOMINICAN REPUBLIC

MINERAL PRODUCTION, 1973-1977

\begin{tabular}{lcrrrr}
\hline Mineral & 1973 & 1974 & 1975 & 1976 & \multicolumn{1}{c}{1977 a } \\
\hline Bauxite (tons) & $1,085,645$ & $1,195,607$ & 785,094 & 621,247 & 574,966 \\
Ferronickel (tons) & 28,298 & 30,942 & 26,922 & 24,399 & 24,899 \\
Gold (tons) & - & - & 6 & 13 & 11 \\
Silver (tons) & - & - & 3 & 28 & 42 \\
Gypsum (tons) & 266,641 & 383,892 & 193,553 & 207,562 & 221,572 \\
Sand (m) & 70,930 & 94,040 & 136,548 & 211,856 & 200,981 \\
Gravel (m 3 ) & 31,740 & 37,260 & 53,824 & 104,219 & 151,127 \\
Limest.one (tons) & 105,970 & 280,247 & 252,097 & 247,612 & 285,623 \\
Salt (tons) & 39,129 & 39,830 & 37,424 & 35,431 & 48,592 \\
\end{tabular}

aprel illiniary fi gures.

Source: Reference 12, p. 47.

has been in surplus each year since 1970,50 with the exception of 1976, as Table 6 shows.

The primary reason for these substantial deficits in the balance of trade since 1975 has been the collapse of the world market price for sugar, the country's main export, together with the increased cost of petroleum. For example, the world market (fob Caribbean ports) price of sugar dropped from U.S. $\$ 0.132$ per pound in December 1975 to U.S. \$0.0709 per pound in October 197751 while the Saudi Arabian (fob Ras Tanura) posted price for crude petroleum jumped from U.S. $\$ 11.53$ per barrel in 1975 to U.S. $\$ 13.00$ per barrel in June of 197752; so that, whereas the DR's sugar sales in 1975 brought in about RD $\$ 522$ million and its oil purchases cost about RD $\$ 169$ million that same year, in 1977 sugar sales brought RD $\$ 218$ million and oil purchases cost RD $\$ 189$ million. 53 The 1979 figures are even more revealing - "sugar sales brought $\$ 225$ million and oil purchases cost $\$ 325$ million" - according to the DR's Minister of Finance, Bolivar Baez Ortiz.54 As of March 1979 internationa) reserves stood at U.S. $\$ 128.2$ million 55 which was equivalent to about one and three quarter months' imports if the January import bill is used as a guide. 56

In 1977, principal imports and exports in descending order of value were as follows:

Ranking of Imports and Exports

\begin{tabular}{ll} 
Imports & Exports \\
\hline Petroleum (crude, products) & Sugar \\
Wheat & Coffee \\
Rice & Cocoa \\
Automobiles (including station & Ferronickel \\
$\quad$ wagons and jeeps) & Gold and silver alloys \\
Peanut oil & Tobacco \\
Corn & Bauxite \\
Buses (micro, omni, trolley) &
\end{tabular}


TABLE 6

DOMINICAN REPUBLIC

BALANCE OF PAYMENTS, 1973-1977

(millions of SDRsa)

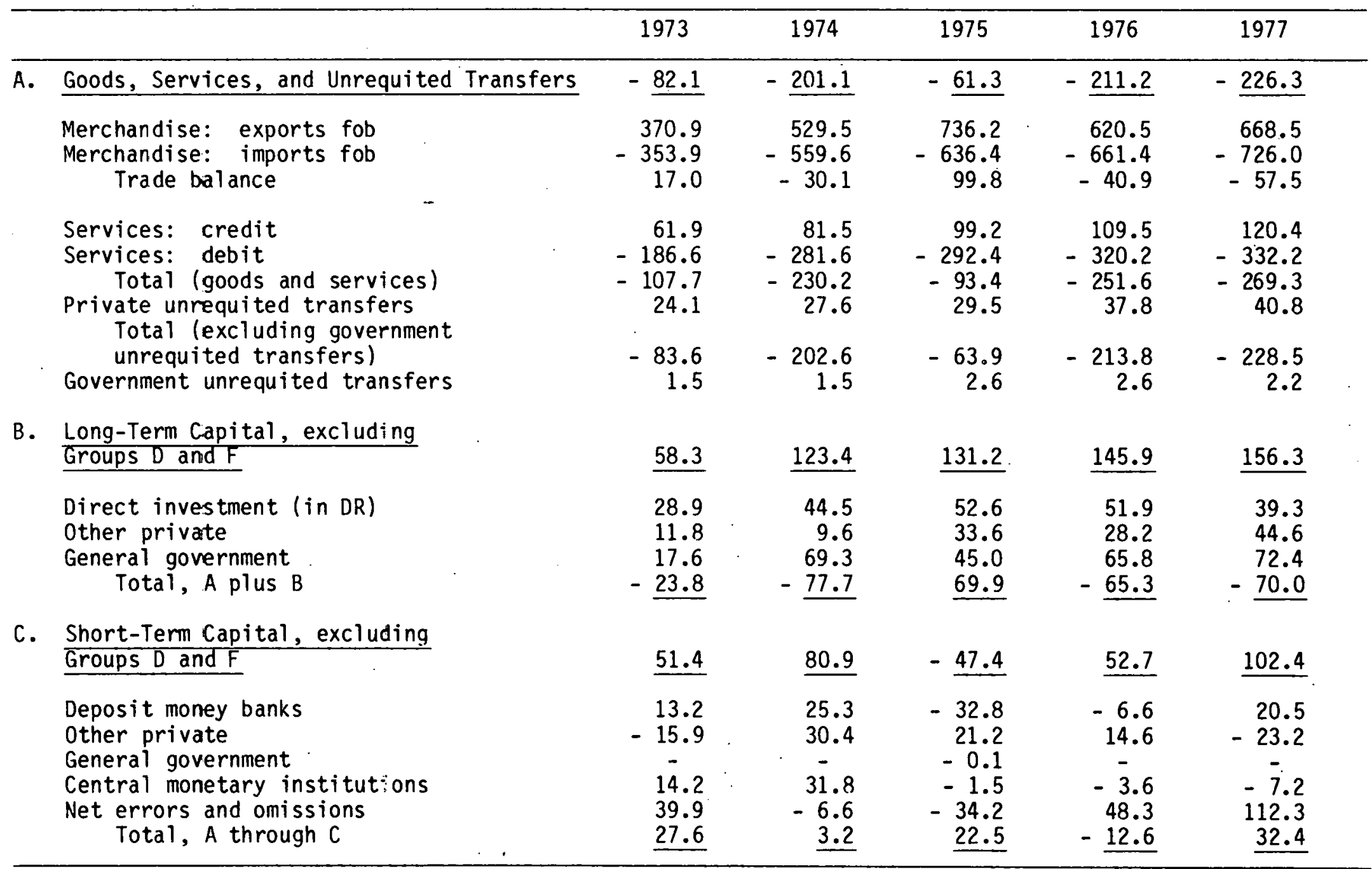




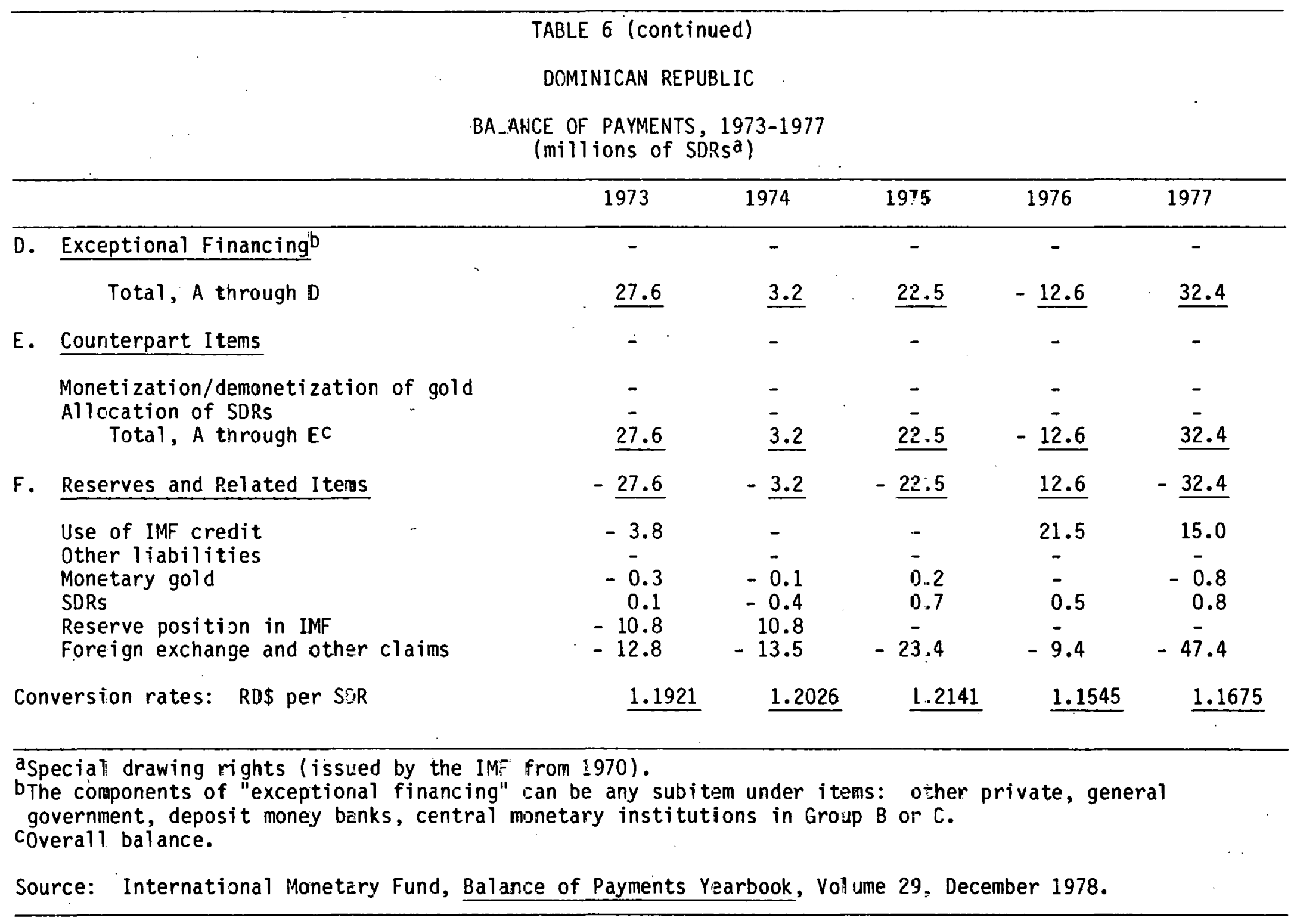




\section{INTRODUCTION \\ NOTES AND REFERENCES}

1. International Monetary Fund, International Financial Statistics (English Edition), Vo1. XXXII, No. 5, May 1979.

2. World Bank Atlas 1978, p. 20.

3. The World Bank estimate for the average annual population growth rate between 1970 and 1976 is 2.9 percent (see World Bank Atlas 1978); and the IMF figure for the same period is al so about 2.9 percent (calculated from International Financial Statistics, Vol. XXX, No. 12, December 1977 and VoI. XXXII, No. 5, May 1979).

4. World Bank, World Economic and Social Indicators, Report No. 700/78/02, p. 42, April 1978.

5. USAID Mission/Dominican Republic, Statistical Data Book, p. 76, June 1977 .

6. The National Statistical Office (Dominican Republic) defines an urban area as one in which there are more than 20,000 inhabitants.

7. For this brief description of the highlands/lowlands topography we drew heavily on Thomas Weil et al., Area Handbook for the Dominican Republic, U.S. Government Printing office, Washington, D.C, 1973.

8. International Monetary Fund, International Financial Statistics (English Edition), Vol. XXXII, No. 5, May 1979.

9. Banco Central de la Republica Dominicana, Boletin Mensual, Vol. XXXII, No. 4, p. 181, April 1979.

10. In 1975, for example, the sugar companies reported more than 81,000 workers (about 7 percent of the labor force) employed in sugar cane production and refining; see Estadistica Industrial de la Republica Dominicana 1975, Oficina Nacional de Estadistica, Boletín No. 23, p. 89 and in 1976 sugar's contribution (in current prices) to GDP was 14 percent; see Duminican Republic: Its Main Economic Development Problems, World Bank, p. 403, December 1978.

11. Oficina Nacional de Estadistica, Estadistica Dominicana 1978 (Seccion 331 Comercio), Vol. XXVI, p. 17; all export figures are quoted at fob value unless stated otherwise.

12. Secretariado Tecnico de la Presidencia (Oficina Nacional de Estadistica), Republica Dominican en Cifras 1978, Vol. VIII, p. 43.

13. Estadistica Dominicana 1978 (Seccion 331 Comercio) Vol. XXVI, p. 18.

14. Ibid.

15. Banco Central de la Republ ica Dominicana, Boletin Mensual, Vol. XXXII, No. 4, April 1979, p. 18. 


\section{INTRODUCTION \\ NOTES AND REFERENCES (continued)}

16. Khan, K. R., International Cocoa Agreement 1975, Food Policy, Vol. 4, Number 1, p. 15, footnote 1, February 1979.

17. Antonini, Gustavo A., Peasant agriculture in northwestern Dominican Republic, Journal of Tropical Geography, Vol. 32, p. 5, 1971.

18. Estadistica Dominicana 1978 (Seccion 331 comercio), Vol. XXVI, p. 19.

19. Mann, Arthur J., Price stabilization policy in a developing economy: the case of the Dominican Republic, Social and Economic Studies, Vol. 26, No. 2, pp. 192-193 (1977)

20. Ämes, Glenn C. W. and Hartley, Jackie W., Sources of Agricultural Credtt and Development in the Dominican Republic, p. 1, College of Agriculture, IIniversity nf feorgia, 1977.

21. The number of ways in which food crops are consumed locally include: home consumption, as sales in the marketplace, as seeds, as payment in-kind, and to a small extent animal consumption.

22. For example, a 1974 sample survey of 2,100 rural households showed that 75 percent of families interviewed for the survey had eaten rice and beans during the previous day while only 33 percent had eaten plantains and 16.2 percent, yucca; see Margaret S. Andrews and John R. Moore, An Integrated Production - Consumption Farm Model for the Dominican Republic, p. 6, Agricultural Experiment Station, University of Maryland, August TY/6.

23. Ames, Glenn C. W., Small farmer associations and development programs: Case of the Dominican Republic, Land Tenure Center Newsletter, No. 52, p. 18, April-June 1976.

24. Encyclopedia Britannica, Book of the Year 1978, p. 308.

25. Republica Dominicana en Cifras 1978, Vol. VIII, p. 43.

26. Ibid., p. 72.

27. Margaret $S$. Andrews and John R. Mott, Integrated Production-Consumption Farm Model for the Dominican Republic, p. 5, Agricultural Experiment Station, University of Maryland, August 1976. It appears, however, that Dominicans do not distinguish between plantains and bananas; both, it seems, are referred to as plantains.

28. Development of Household Food Behavior Models, p. 47, prepared for the Agency for International Development, Poynor International Incorporated, Silver Spring, Maryland, Dec. 1.976.

29. Secretariat of Agriculture (SEA), Plan Operativo 1978, Anexo 1.

30. Ibid. 


\section{INTRODUCTION \\ NOTES AND REFERENCES (continued)}

31. Ibid.

32. Ibid., Table 14.

33. Boletin Mensual, Banco central de la Republica Dominicana, Vol. XXXII, No. 4, p. 192, Apri1 1979.

34. Only about 16,352 tons of salad tomatoes were produced in 1977; see Plan Operativo 1978, Anexo 1, Table 14.

35. Annual per capita consumption of peanut oil in the DR is about 20 pounds; see Diagnostico Y Estrategia Del Desarrollo Agropecuario 1976-1986, Secretaria Del Estado de Agricultura, p. 197.

36. Republica Dominicana en Cifras 1978, p. 43.

37. P.lan Operativo 1978, Anexo 1.

38. Banco central de la Republica Dominicana, Vol. XXXIII, No. 4, p. 182, Apri 11.979.

39. Sachtler, M., Einige Ergebmisse der Waldenventum.....Forstwirtschaft, Mitt Bundesforschungsanst Forst Holzwirtsch, Vo1. 99, pp. 95-118, Sept. 1974.

40. Oficina National de Estadistica, Indice de la Produccion Industrial Manufacturera, No. 12, p. 8, 1979.

41. The average annual growth rates for these sectors during 1973-77 were as follows - agriculture $0.7 \%$, livestock $3.5 \%$, forestry/fishing $-4.2 \%$, electricity $10.6 \%$, mining $9.2 \%$, construction $7.4 \%$, and transportation $7 \%$.

42. Republica Dominicana en Cifras 1978, Vol. VIII, P. 50.

43. Ibid., p. 51.

44. Banco Central de la Republica Dominicana, Boletin Mensual, Vol. XXXII, No. 4, p. 194, April 1979.

45. Ibid., pp. 117-118.

46. Ibid., pp. 120-121.

47. United Nations, Yearbook of International Trade Statistics 19/6, volume II.

48. Boletin Mensual, April 1979, op. cit., p. 115.

49. For 1970-77 figures, see International Monetary Fund, Balance of Payments Yearbook, Vol. 29, December 1978; for preliminary 1978 data, see Boletín MensuaT, op. cit., p. 127. 


\section{INTRODUCTION \\ NOTES AND REFERENCES (continued)}

50. Balance of Payments Yearbook, Vol. 29, 1978.

51. Boletin Mensual, op. cit., p. 167.

52. World Bank, Commodity Trade and Price Trends (1977 Edition), p. 92, Report No. EC-166777, August 1977.

53. Figures for 1975 and 1977 sugar sales are from Boletin Mensual, April 1979; and figures for 1975 and 1977 oil purchases are from Thomas V. Long, et al., The Rational Use of Energy in the Dominican Republic, report to the Inter-American Development Bank, 22 May 1979.

54. Thomas, Jo, After a year, Dominican Democracy still feeling its way, The New York Times, p. 2, Saturday. August 25. 1919.

55. International Monetary Fund, International Financial Statistics (English Edition), Vol. XXXII, No. 5, p. 125, May 1979.

56. In January 1979 the import bill was RD $\$ 72.1$ million; see Boletin Mensual, op. cit., p. 103. 


\section{ENERGY RESOURCES AND PRODUCTION}

\subsection{COMMERCIAL ENERGY}

\section{$2.1 .1 \quad 0 i 1$}

Although oil-bearing formations are known to exist in the southwestern portion of the Dominican Republic, no commercially significant deposits have been identified. The exploration efforts have been sporadic, however, and a more comprehensive evaluation of the oil resources is planned: As of 1976, only eight potential oil-bearing structures had been drilled, one of which (Maleno in the Azua province) produced small amounts of oil.1 The existence of valuable oil resources cannot be ruled out, al though it appears unlikely that domestic oil will displace significant quantities of imported oil, at least in the near future.

In the absence of any domestic production, the Dominican Republic has had to rely on imports to satisfy all of its oil requirements. The value of imports of petroleum and petroleum products for the 1967 to 1977 period is given in Table 7. The sixfold increase between 1971 and 1974 is the result of increases in both the petroleum prices and, as illustrated in Table 8 , the quantities imported.

The composition of the petroleum imports changed significantly with the installation of an oil refinery in the port of Haina near Santo Domingo. The refinery, owned jointly by the Dominican government and She11, had its first full year of operation in 1973. Reconstituted crude oil, consisting of approximately 60 percent crude and 40 percent semifinished products, is imported from Venezuela to supply both the refinery and some electricity generation in the industrial sector. The refinery capacity is approximately 11 million barrels ${ }^{2}\left(67 \times 10^{15}\right.$ joules $)$ a year and its historical outputs are given in Table 9. With the exception of fuel oil, the refinery production has displaced most of the petroleum product imports.

TABLE 7

IMPORTS OF PETROLEUM AND PETROLEUM DERIVATIVES 3 (Millions of RD \$)

\begin{tabular}{ccccc}
\hline Year & $\begin{array}{c}\text { Refined } \\
\text { Fuel Products }\end{array}$ & $\begin{array}{c}\text { Nonfuel } \\
\text { Petroleum Derivatives }\end{array}$ & $\begin{array}{c}\text { Reconstituted } \\
\text { Crude }\end{array}$ & Total \\
\hline 67 & 11.2 & 1.8 & --- & 13.0 \\
70 & 16.2 & 2.8 & -- & 19.1 \\
71 & 22.0 & 3.5 & --- & 25.4 \\
72 & 19.3 & 11.0 & 7.8 & 38.1 \\
73 & 14.6 & 10.7 & 29.4 & 54.7 \\
74 & 26.1 & 12.1 & 118.5 & 156.8 \\
75 & 20.0 & 13.5 & 143.8 & 177.2 \\
76 & 14.3 & 22.9 & 146.6 & 183.8 \\
77 & 18.6 & 11.1 & 158.0 & 187.8 \\
\hline
\end{tabular}

Source: Reference 2. 


\section{TABLE 8}

IPPORTS OF PETROLEUM AND PETROLEUM DERIVATINES

(1015 joules)

\begin{tabular}{|c|c|c|c|c|c|c|c|c|c|c|}
\hline Year & Gasol ine & $\begin{array}{l}\text { Aviation } \\
\text { Gasoline }\end{array}$ & Fuel 0 il & Gas Jil & Kerosine & LPG & $\begin{array}{c}\text { Reconstituted } \\
\text { Crude }\end{array}$ & $\begin{array}{l}\text { Total } \\
\text { Fuel }\end{array}$ & $\begin{array}{l}\text { Non- } \\
\text { Fuel }\end{array}$ & Total \\
\hline $\begin{array}{l}67 \\
70 \\
71 \\
72 \\
73 \\
74 \\
75 \\
76 \\
77\end{array}$ & $\begin{array}{r}8.0 \\
9.0 \\
11.1 \\
11.5 \\
2.0 \\
--- \\
--- \\
---\end{array}$ & $\begin{array}{l}0.3 \\
0.6 \\
0.5 \\
0.6 \\
1.2 \\
2.1 \\
1.5 \\
0.1 \\
0.2\end{array}$ & $\begin{array}{r}8.2 \\
13.9 \\
5.7 \\
12.6 \\
4.9 \\
12.6 \\
6.0 \\
8.1 \\
10.0\end{array}$ & $\begin{array}{r}4.4 \\
6.2 \\
10.2 \\
6.4 \\
1.8 \\
1.9 \\
1.6 \\
0.2 \\
0.5\end{array}$ & $\begin{array}{l}1.7 \\
3.5 \\
2.9 \\
1.4 \\
0.2 \\
--- \\
--- \\
--- \\
---\end{array}$ & $\begin{array}{l}0.4 \\
1.1 \\
1.2 \\
--- \\
-\cdots \\
--. \\
\text { N.A. } \\
\text { N.A. } \\
---\end{array}$ & $\begin{array}{r}.-- \\
-- \\
--- \\
17.8 \\
54.5 \\
54.8 \\
7 \Xi .8 \\
74.5 \\
7 \Xi .8\end{array}$ & $\begin{array}{l}23.0 \\
34.3 \\
31.7 \\
50.3 \\
74.6 \\
81.4 \\
82.9 \\
82.9 \\
84.5\end{array}$ & $\begin{array}{r}1.5 \\
5.1 \\
2.8 \\
17.9 \\
25.9 \\
6.8 \\
1.5 \\
3.0 \\
3.1\end{array}$ & $\begin{array}{r}24.5 \\
39.4 \\
34.5 \\
68.2 \\
100.5 \\
88.2 \\
84.4 \\
85.9 \\
87.6\end{array}$ \\
\hline
\end{tabular}


TABLE 9

REF INERY OUTPUTS, $1973-77$

(1015 joules)

\begin{tabular}{ccccccc}
\hline Year & Gasoline & Fuel Dil & Gas 0il & Kerosine & LPG & Total \\
\hline 73 & 11.7 & 10.5 & 6.8 & 2.3 & 1.5 & 32.1 \\
74 & 12.7 & 10.2 & 12.3 & 2.3 & 2.0 & 39.5 \\
75 & 14.7 & 15.7 & 15.0 & 2.3 & 2.2 & 50.9 \\
76 & 15.1 & 17.8 & 15.9 & 2.2 & 2.4 & 53.4 \\
77 & 15.1 & 17.5 & 16.4 & 2.1 & 2.6 & 53.7 \\
\hline
\end{tabular}

Source: Reference 4.

\subsubsection{Coal and Peat}

Peat and Tignite deposits have been identified in the Bajo Yuna area and on the Samana peninsula, but the magnitude and quality of these reserves have not been quantified. 5 It is, therefore, impossible to determine whether the deposits will warrant exploitation. With no domestic coal production to date, the Dominican Republic has had to import small quantities of coal. On the basis of industrial consumption statistics 6 it would appear that coal imports were less than 200 tons in 1977.

\subsubsection{Hydropower}

The theoretical hydroelectric generation potential in the Dominican Republic has been estimated at $50,000 \times 10^{6} \mathrm{kWh}\left(180 \times 10^{15}\right.$ joules $)$ per annum, of which between 10 and 40 percent could technically be developed. 7 In the absence of comprehensive hydrographic data, however, such estimates are necessarily very uncertain and it may mean more to consider only the hydropotential from sites which have already been evaluated. As of 1976, fifty sites 8 had been identified with a total capacity of approximately $1 \mathrm{GW}_{\mathrm{e}}$ and an electricity generation capability of 2,500 GWh per annum. A small number of minihydro sites (less than $5000 \mathrm{~kW}_{\mathrm{e}}$ ) had al so boen identified.

In the past the development of the hydroelectric resources has been hindered by the high capital costs, the relatively long lag time, and the existence of competing water requirements (principally irrigation). With the current oil prices, however, the development of hydro sites has become more costeffective.

The historical development of hydro capacity is given in Table 10. Only 13 percent of the total capacity of identified sites have been developed. In addition, the Taveras and Valdesia plants have been operating sporadically and in early 1977 they were achieving only 20 to $40 \mathrm{MW}_{\mathrm{e}}$ compared to a nominal capacity of $136 \mathrm{MW}_{e}$. This was largely the result of water releases for irri- 
gation which have prevented the reservoirs from filling and accounts for the relatively low electricity generation figures given in Table 11.

\subsubsection{Solar and Wind}

The information on the solar resources of the Dominican Republic is 1 imited to radiation data from four sites, sunshine hour data from seven sites and cloud cover estimates from a total of 24 sites. 10 Acosta, 11 basing his calculations on the correlation between cloud cover and solar radiation, estimates an annual average radiation of 2000 joules per $\mathrm{cm}^{2}$ for the 24 stations measuring cloud cover. On a monthly basis the average radiation estimate varies from 1800 joules per $\mathrm{cm}^{2}$ for January to 2300 for July.

Although the existing estimates show relatively high levels of solar radiations, this fuel source is virtually untapped at present. One company, Energia Solare S.A., has been manufacturing solar water heaters but has sold only 300 units in the last three years.

Data on the wind energy resources of the Dominican Republic appear to be even more limited, perhaps because the information that does exist is nnt. promising. The average wind speed at the meteorological sites has been estimated at about $4 \mathrm{~m} / \mathrm{s}$ (which is well below the optimal wind speed for most commercial windmills). Tabor 12 estimates that there are probably 500 or more very small windmills used in remote areas without electricity but that they are being replaced by electricity and gasoline pumps.

TABLE 10

HYURRU LAYACIIY EXPANSION

\begin{tabular}{cll}
\hline $\begin{array}{c}\text { Date of } \\
\text { Installation }\end{array}$ & Location & $\begin{array}{c}\text { Nominal } \\
\text { Capacity }(\mathrm{kWe})\end{array}$ \\
\hline 1949 & Cunslaniza & 250 \\
1959 & Jimenon & 7500 \\
1966 & Las Damas & 7500 \\
1973 & Taveras I & 40000 \\
1973 & Taveras II & 40000 \\
1975 & Valdesia & 27000 \\
1975 & Valdesia & 27000 \\
& Total Capacity & 149250
\end{tabular}

Source: Reference 9. 
TABLE 11

HYDROELECTRIC GENERATION 1967-75

(GWh)

\begin{tabular}{ccccccc}
\hline Year & Jimenon & Las Damas & Constanza & Tavera & Valdesia & Total \\
\hline 67 & 36.7 & 9.7 & 0.7 & & & 47.1 \\
70 & 57.0 & 24.3 & & & & 81.3 \\
71 & 39.8 & 26.3 & 1.1 & & & 71.2 \\
72 & 48.1 & 22.4 & 1.2 & & & 183.7 \\
73 & 39.5 & 18.4 & 1.3 & 123.8 & & 178.7 \\
74 & 40.4 & 17.0 & 1.2 & 120.1 & 15.3 & 161.9 \\
75 & 34.4 & 18.1 & 1.5 & 92.6 & & \\
76 & & & & & &
\end{tabular}

Source: Marcelo Jorge Perez, Caracteristicas generales de la demanda y la oferta de energia, in CODIA 50, 1976.

\subsubsection{Geothermal}

There are a number of indications that the Dominican Republic may have significant geothermal resources. Geographically, the country lies in a tectonically active region, a prerequisite for the existence of high temperature geothermal resources. Past lava emissions and volcanic activity have been identified in geological studies and thermal springs exist along one of the island's faults. In addition, a chemical analysis13 of the two major thermal springs (Yayas and Maguella in the Azua Province) showed a similar chemical composition to spring waters in currently exploited geothermal sites. It is possible, however, that the geothermal resources are limited to low grade heat with limited applications, and further exploration (including drillings) is required to determine the extent and quality of this resource.

\subsection{NONCOMMERCIAL ENERGY}

\subsubsection{Fürest Resuurces}

According to a forest inventory for the Dominican Republic 14 published in 1973, there are about one million hectares of forest in the Dominican Republ ic accounting for approximately 22 percent of its surface area. The forests are located principally in the southwest and in the east along the coast. of the forested area, only 34 percent was found in its natural state, the remainder having been partially depleted by logging (38 percent), charcoal production (17 percent), or forest fires, grazing, and nomadic agriculture (11 percent). The previously high rate of deforestation has decreased significantly, however, since most of the forests are now located in areas with poor growing conditions, and logging has been under strict government control since 1967 .

The energy potential of the forested area depends on the forest management techniques, the quantity of wood destined to nonenergy uses, and the quantity of wood which is not economically exploitable (e.g., inaccessible). 
If all of the forested area was in its natural state and could be exploited for fuel purposes, the total sustainable yield of roundwood would be roughly $38 \times 1015$ joules per annum (see Table 12). Excluding 200,000 hectares which are considered inaccessible, the figure falls to approximately $30 \times 10^{15}$ joules. As noted above, however, most of the accessible forest land has been partially depleted and these estimates are upper limits to the potential roundwood production of the forested areas; currently sustainable yields could be as little as half of these estimates and a significant portion is likely to go to nonfuel uses.

In addition to the wood resources on forested areas noted above, wood can be collected from the trees located outside of forests and from tree stumps and branches not included in the forest inventory. Reforestation projects and tree farms could also add significantly to the wood reserves. However, in the absence of adequate data, we will not attempt to assess these resources.

Estimates of the actual production of fuelwood and charcoal are given in Tables 13 and 14. The discrepancies between the two estimates are insignificant given the level of uncertainty in the efficiency of charcoal production. Calculations based on a national household survey, ${ }^{*}$ however, yield an estimate of $5.7 \times 10^{15}$ joules for charcoal in 1977, well above the charcoal production estimate given in Table 13. In any case, it is evident that wood production is high relative to the resource base and, if indiscriminate cutting continues, the remaining forests will be rapidly depleted.

\subsubsection{Agricultural Residues}

Approximately 20 percent of the Dominican Republic's land area, which amounts to about one million hectares, is under agricultural cultivation. Table 15 shows the production of most of the major crops and rough estimates

TABLE 12

SUSTAINABLE YIELD OF FORESTED AREA

(Under Average Conditions)

\begin{tabular}{llcc}
\hline Forest Type & $\begin{array}{c}\text { Aresa } \\
\left(10^{3} \mathrm{ha}\right)\end{array}$ & $\begin{array}{c}\text { Net Primaryb } \\
\text { Production } \\
\left.\mathrm{J} \times 10^{9} / \mathrm{ha}\right)\end{array}$ & $\begin{array}{c}\text { Total Annual } \\
\text { Production } \\
\left(\mathrm{J} \times 10^{5}\right)\end{array}$ \\
\hline $\begin{array}{l}\text { Pine/Mixed } \\
\text { Dry }\end{array}$ & 335,000 & 42 & 14 \\
Moist Deciduous & 400,000 & 14 & 6 \\
& $\underline{250,000}$ & 70 & $\underline{18}$ \\
\hline
\end{tabular}

Source: aReference 14.

bD. E. Earl, Forest Energy and Economic Development, oxford University Press, 1975.

*An unpublished survey by the Central Bank's Department of Economic Studies. 
of the agriculture residues produced with their energy content. Sugarcane alone accounts for at least 70 percent of the energy content of these agricultural residues and is currently the only one used extensively as a fuel (although small amounts of peanut residue consumption are also recorded). Sugarcane residue, or bagasse, is used principally as a fuel for electricity generation for sugar processing. In addition, Central Romana, a subsidiary company of Gulf and Western which mills approximately 3 million tons of sugarcane a year, uses the bagasse as a feedstock in the production of approximately

TABLE 13

WOOD PRODUCTION (FAO), 1967-77

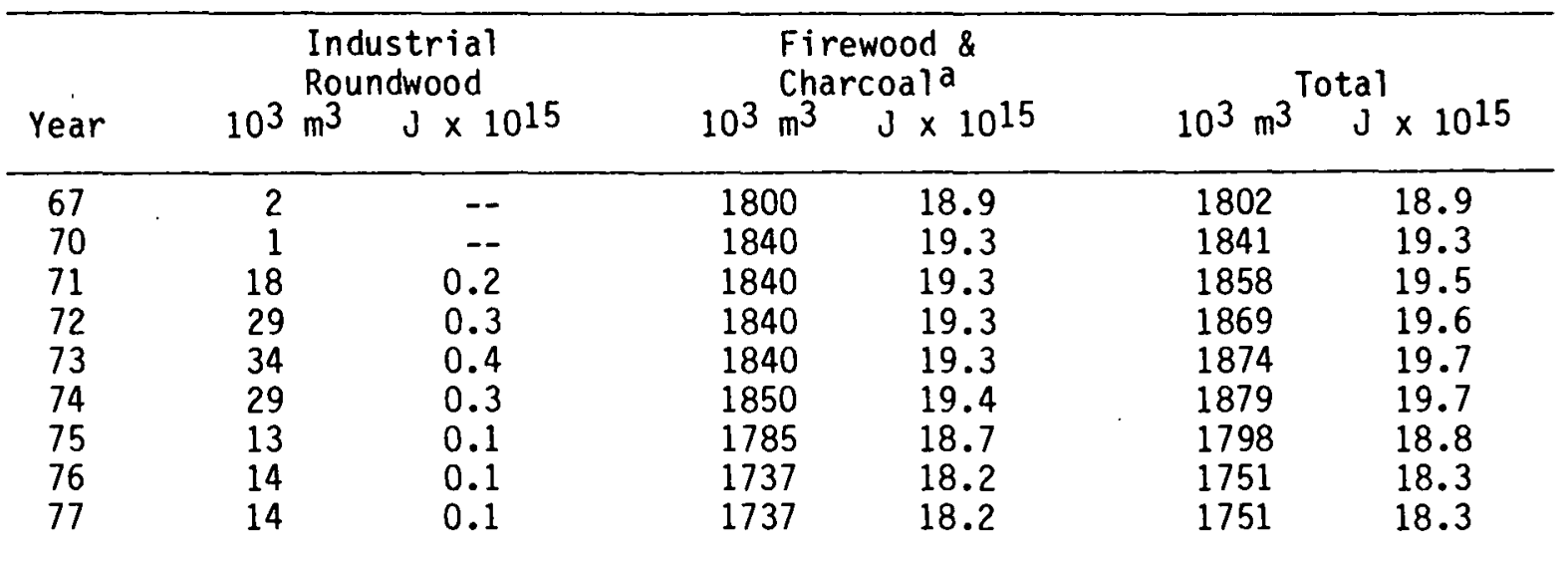

Source: Reference 15.

aCharcoal has been converted into wood equivalent.

TABLE 14

WOOD AND CHARCOAL RESOURCE USE, 1973-77

(1015 joules)

\begin{tabular}{cccc}
\hline Year & Wood & Charcoal & $\begin{array}{l}\text { Total Wood } \\
\text { Equivalenta }\end{array}$ \\
\hline 73 & 13.5 & 1.4 & 15.8 \\
74 & 14.0 & 1.4 & 16.3 \\
75 & 14.1 & 1.5 & 16.6 \\
76 & 14.2 & 1.6 & 16.9 \\
77 & 14.4 & 1.6 & 17.1 \\
\hline
\end{tabular}

Source: Reference 16.

aAssuming a 40 percent energy loss in converting wood to charcoal. 
TABLE 15

CROP RESIDUES, 1977

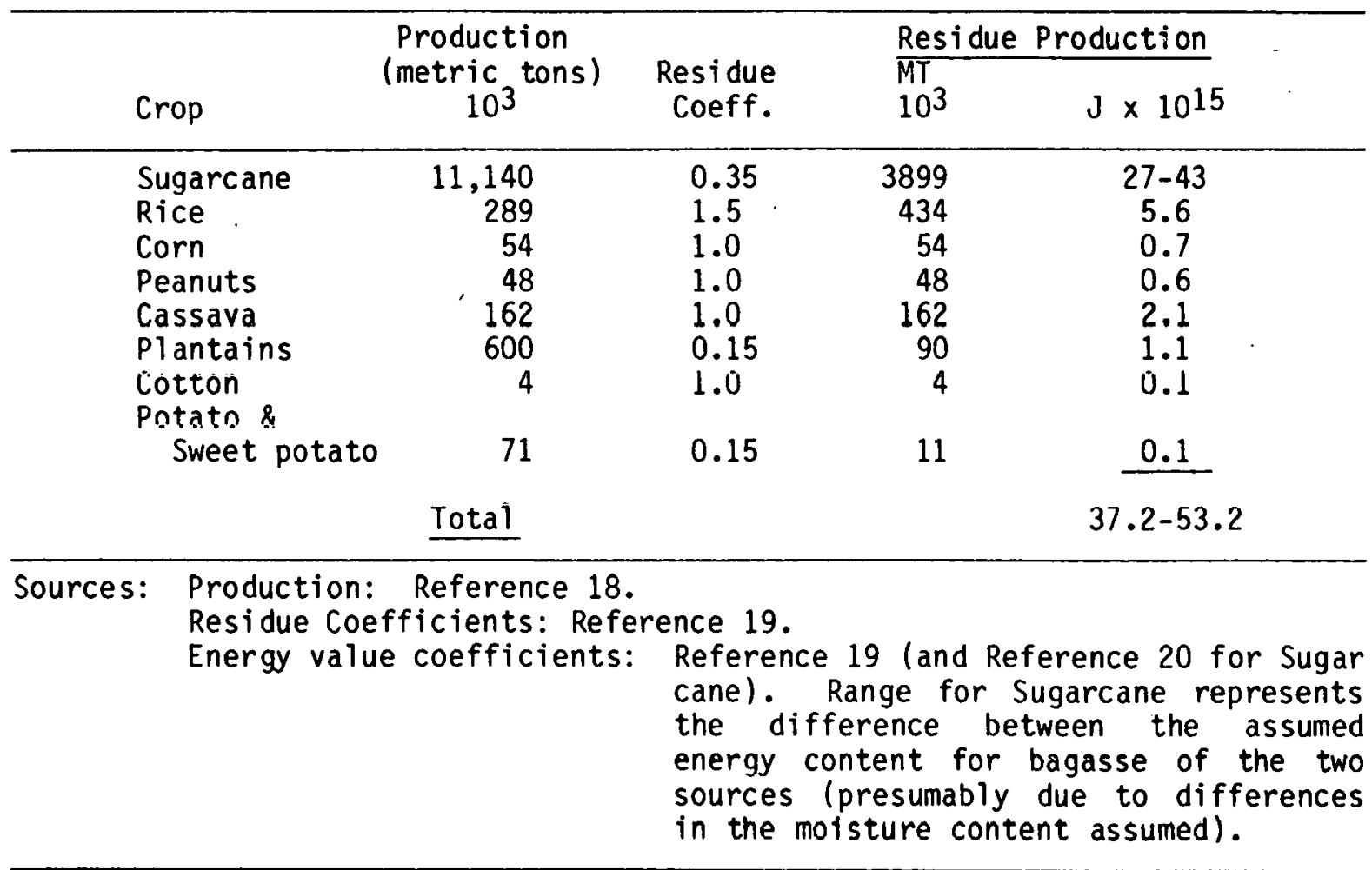

39,000 tons of furfural a year. The furfural residue also has a high energy content, and apparently very little of the energy content of the bagasse is lost in this process. 17 Molasses, another sugarcane residue, is consumed domestically by the feed and alcohol (primarily rum) industries, or exported.

The use of residues from crops other than sugar is constrained by the difficulties involved in collection. Thus it is not realistic to assume that this resource could be utilized fully for energy conversion.

\subsubsection{Animal Waste}

of the animals listed in Table 16, only cattle produce large quantities of animal waste. Poultry might al so produce significant quantities but we could not obtain data adequate to provide an estimation. Apparently, animal waste is not currently used as a fuel and, as in the case of crop residues, collection problems are likely to prevent it from ever being used in full. 
TABLE 16

ANIMAL RESIDUES 1971

\begin{tabular}{|c|c|c|c|c|}
\hline Animal & Head $(000)^{a}$ & Residue Coeff.b & $\begin{array}{l}\text { Residue } \\
\text { metric } \\
\text { tons }(000)\end{array}$ & $\frac{\text { oduction }}{J \times 10^{15}}$ \\
\hline $\begin{array}{l}\text { Cattle } \\
\text { Pigs } \\
\text { Sheep } \\
\text { Goats } \\
\text { Horses } \\
\text { Mules } \\
\text { Asses }\end{array}$ & $\begin{array}{r}1712 \\
876 \\
26 \\
283 \\
217 \\
98 \\
115\end{array}$ & $\begin{array}{l}1.7 \\
0.11 \\
0.11 \\
0.11 \\
1.5 \\
0.11 \\
0.11\end{array}$ & $\begin{array}{r}2,900 \\
96 \\
3 \\
31 \\
326 \\
11 \\
13\end{array}$ & $\begin{array}{r}42 \\
1 \\
-- \\
-- \\
5 \\
-- \\
--\end{array}$ \\
\hline & & \multicolumn{2}{|c|}{ Total } & 48 \\
\hline es: & $\begin{array}{ll}\text { nce } 18 . \\
\text { nce } 19 .\end{array}$ & & & \\
\hline
\end{tabular}




\section{ENERGY RESOURCES AND PRODUCTION}

\section{NOTES AND REFERENCES}

1. Romeo Llinas, Perspectivas energeticas de la Republica Dominicana: Posibilidades Petroliferas, in CODIA 50, Colegio Dominicano de Ingenieros, Arquitectos y Agrimensores, 1977.

2. T. V. Long, II, The Rational Use of Energy in the Dominican Republic, report to the Inter-American Development Bank, 22 May 1979.

3. Note: Slight inconsistencies existed in the original table (in Reference 2 ), and crude imports by Gulf and Western may not be accounted for.

4. Oficina Nacional de Estadistica, Republica Dominicana en Cifras 1978.

5. Roberto Liz, et al., Evaluacion de la Situation Energetica Nacional, Banco Central de la Republica Dominicana, Santo Domingo, 1978.

6. Oficina Nacional de Estadistica, unpublished data.

7. Marcelo Jorge Perez, Fuentes Potenciales de Energia, Santo Domingo, IDEA, 1974.

8. Rafael Augusto Pelleramo, Planes de aprovechamiento de los recursos hidraulicos, in CODIA 50, op. cit.

9. T. V. Long, op. cit.

10. H. Tabor, Solar Energy in the Dominican Republic, report to the Inter-American Development Bank, forthcoming.

11. Discussed in Tabor, ibid.

12. H. Tabor, ibid.

13. Described in Corporacion Dominicana de Electricidad, Geotermia, 1978.

14. Inventario y Fomento de los Recursos Forestales, Republica Dominicana, Informe tecnico 3, FAO, UNDP, Rome 1973.

15. FAO, Yearbook of Forest Products - 1966-1977.

16. Roberto Liz et al., op. cit.

17. T. V. Long, op. cit.

18. Oficina Nacional de Estadistica, Republica Dominicana en Cifras, 1978.

19. U.S. Department of Energy, Joint Peru/United States Report of Peru/United States Cooperative Energy Assessment, Annex 8, August 1979. 


\section{ENERGY CONSUMPTION PATTERNS}

\subsection{TRENDS AND CHARACTERISTICS}

Total energy resource consumption in the Dominican Republic increased from approximately 74 quadrillion joules in 1970 to 129 quadrillion joules in 1977, with an annual average growth rate of about 8 percent. Over the same period, per capita energy consumption rose from 18.5 billion (109) joules to 25.9 billion joules.

As illustrated in Table 17, most of this growth was in the consumption of oil-based fuels which accounted for almost two thirds of energy consumption in 1977 compared to less than half in 1970. The striking increases in oil consumption between 1971 and 1973 correspond to a period of high economic growth (GDP at constant market prices grew at over 11 percent a yearl) and to the opening of the Haina oil refinery. Subsequently, after the OPEC price increases and the fall in the sugar prices in 1976, the growth in oil consumption declined and between 1974 and 1977 it averaged less than 2 percent. of the estimated 64 quadrillion joules of oil consumed in 1977, fuel oil accounted for 34 percent, gas oil 20 percent, crude 21 percent, gasoline 18 percent, and kerosine and LPG 3 percent each.

Hydro resources still accounted for only 2.2 percent of energy resource consumption in 1977 in spite of a comparatively high annual growth rate of 16 percent. As noted in Section 2, competing water requirements for irrigation have prevented the existing hydro capacity from being used effectively. In the absence of such difficulties the hydroelectric generation could have been far greater than the actual figures.

Wood consumption (including charcoal) fell slightly and accounted for only 14 percent of energy consumption in 1977, down from 26 percent in 1970 . This decrease is probably brought on by rural to urban migration and rising household income causing households to substitute oil based fuels for part of their wood consumption. It should be noted, however, that these figures do not imply that the wood consumption is having a smaller effect on the forest resources. The level of wood consumption has been decreasing very slowly (if at all), and if more wood is being purchased on the comercial market (as is likely to be the case since urban households cannot collect wood locally) the roundwood consumption may actually have grown significantly. While rural households tend to obtain a large proportion of their wood from branches and twigs, whose collection does not harm the forests significantly, the commercial wood is likely to be roundwood and charcoal obtained from felling.

Bagasse consumption, which is intimately linked with sugarcane production, grew at an annual rate of 4 percent. There is a possibility, however, that a significant portion of the bagasse reported here (which is approximately equal to production) was not used as fuel. There are discrepancies between the bagasse consumption estimates and some bagasse is used as animal feed and in producing furfural.

In addition to the energy consumption recorded in Table 17 , small amounts of other crop residues, solar and wind energy, and coal are used. These energy sources do not make up a significant portion of total energy consumption, however. 
TABLE 17

ENERGY CONSUMPTION, $1970-77$

(joules $\times 10^{15}$ )

\begin{tabular}{|c|c|c|c|c|c|c|c|c|c|}
\hline \multirow[b]{2}{*}{ Year } & \multicolumn{2}{|c|}{$0 i l$ fuels $\mathrm{s}^{\mathrm{a}}$} & \multicolumn{2}{|c|}{ Hydrob } & \multicolumn{2}{|c|}{ Wood + Charcoalc } & \multicolumn{2}{|c|}{ Bagassed } & \multirow{2}{*}{$\begin{array}{l}\text { Total } \\
1015 \mathrm{~J}\end{array}$} \\
\hline & $10^{15} \mathrm{~J}$ & $\%$ & $10^{15 \mathrm{~J}}$ & $\%$ & $10^{15} \mathrm{~J}$ & $\%$ & $10^{15} \mathrm{~J}$ & $\%$ & \\
\hline $\begin{array}{l}70 \\
71 \\
72 \\
73 \\
74 \\
75 \\
76 \\
77\end{array}$ & $\begin{array}{l}34.3 \\
31.7 \\
47.1 \\
70.0 \\
77.7 \\
77.1 \\
78.7 \\
82.4\end{array}$ & $\begin{array}{l}46 \\
42 \\
53 \\
61 \\
63 \\
65 \\
63 \\
64\end{array}$ & $\begin{array}{l}1.0 \\
0.8 \\
0.9 \\
2.2 \\
2.1 \\
1.9 \\
3.6 \\
2.8\end{array}$ & $\begin{array}{l}1 \\
1 \\
1 \\
2 \\
2 \\
2 \\
3 \\
2\end{array}$ & $\begin{array}{l}19.3 \\
19.3 \\
19.3 \\
19.3 \\
19.4 \\
18.7 \\
18.2 \\
18.2\end{array}$ & $\begin{array}{l}26 \\
26 \\
22 \\
17 \\
16 \\
16 \\
15 \\
14\end{array}$ & $\begin{array}{l}19.6 \\
23.1 \\
22.4 \\
23.2 \\
23.3 \\
21.5 \\
25.2 \\
25.6\end{array}$ & $\begin{array}{l}26 \\
31 \\
25 \\
20 \\
19 \\
18 \\
20 \\
20 .\end{array}$ & $\begin{array}{r}74.2 \\
74.9 \\
89.7 \\
114.7 \\
122.5 \\
119.2 \\
125.7 \\
129.0\end{array}$ \\
\hline
\end{tabular}

Sources: Table 8 this report. Refinery losses are not included.

b1970-75 from Section III, Table 11 (converted to fossil fuel equivalent assuming $30 \%$ efficiency). 1976-77 from Roberto Liz et al. 3

CFAO estimates of wood production 4 converted to energy assuming $14 \times 10^{9}$ joules/ton.

d1970-72 from World Bank estimates of Bagasse production' 1 converted to energy assuming $7 \times 10^{9}$ joules/ton. 1973-77 from Robert Liz et al.3

\subsection{SECTORAL CONSUMPTION}

The energy use in the Dominican Republic by major consuming sector is summarized in Table 18. The industrial sector appears to be the largest energy consumer, accounting for 38 percent of the oil, 61 percent of the biomass energy consumption, and 38 percent of the electricity sold by the public utility. An additional 19 percent of total resource consumption is lost in the generation and transmission of the public sector electricity. Transportation, which depends totally on oil-based fuels, accounts for about 22 percent of the oil consumption but only 15 percent of total energy use. The residential sector is the next largest total energy consumer, but 66 percent of the residential energy is from wood (either directly or in the form of charcoal) which is used inefficiently: the amount of useful energy required by the residential sector is comparatively small.

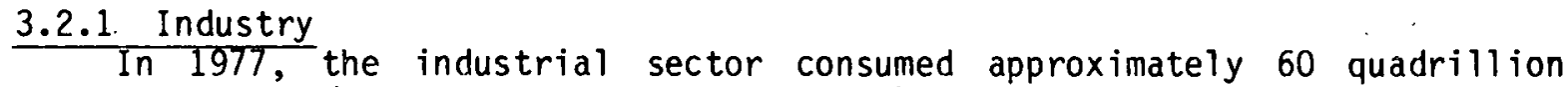
joules of fuel (including electrical energy). Estimates of fuel consumption by industrial category for 1975 are given in Table 19. Most of the bagasse and crude $0 i 1$ and part of the fuel oil and gas oil consumption are apparently used for captive electricity generation (electricity generated by the industries themselves), and approximately 57 percent of the electricity consumption 
TABLE 18

ENERGY CONSUMPTION BY SECTOR AND RESOURCE, 1977

(1015 joules)

\begin{tabular}{|c|c|c|c|c|c|c|c|c|c|c|c|c|c|c|}
\hline & $\begin{array}{l}\text { Gaso- } \\
\text { line }\end{array}$ & $\begin{array}{l}\text { Avia- } \\
\text { tion } \\
\text { Fuel }\end{array}$ & $\begin{array}{l}\text { Fuel } \\
\text { oil }\end{array}$ & $\begin{array}{l}\text { Gas } \\
0 \text { il }\end{array}$ & $\begin{array}{l}\text { Kero- } \\
\text { sene }\end{array}$ & LPG & Crude & $\begin{array}{c}\text { Total } \\
0 \text { il }\end{array}$ & Hydro & $\begin{array}{l}\text { Elec- } \\
\text { tricity } \\
\text { Purchases }\end{array}$ & Bagasse & Wood & $\begin{array}{l}\text { Char- } \\
\text { coal }\end{array}$ & TOTAL \\
\hline $\begin{array}{l}\text { Industrya } \\
\text { Transportationb } \\
\text { Residentialc } \\
\text { Public Utilityd } \\
\text { Othere }\end{array}$ & $\begin{array}{l}0.7 \\
14.3 \\
-- \\
--\end{array}$ & $\begin{array}{l}-- \\
0.2 \\
-- \\
--\end{array}$ & $\begin{array}{l}8.6 \\
-- \\
-- \\
19.5\end{array}$ & $\begin{array}{l}5.5 \\
4.0 \\
-- \\
5.6 \\
1.6\end{array}$ & $\begin{array}{l}-- \\
2.3 \\
--\end{array}$ & $\begin{array}{l}0.1 \\
-- \\
2.5 \\
--\end{array}$ & $\begin{array}{l}16.4 \\
-- \\
-- \\
1.1^{f}\end{array}$ & $\begin{array}{r}31.3 \\
18.5 \\
4.8 \\
26.5 \\
1.6\end{array}$ & $\begin{array}{l}-- \\
-- \\
2.8 \\
--\end{array}$ & $\begin{array}{l}2.1 \\
-- \\
2.1 \\
(-5.6) \\
1.4\end{array}$ & $\begin{array}{l}25.6 \\
-- \\
-- \\
--\end{array}$ & $\begin{array}{l}1.0 \\
-- \\
7.7 \\
--\end{array}$ & $\begin{array}{l}-- \\
5.7 \\
--\end{array}$ & $\begin{array}{r}60.0 \\
18.5 \\
20.3 \\
23.4 \\
3.0\end{array}$ \\
\hline $\begin{array}{l}\text { Total } \\
\text { Consumption }\end{array}$ & 15.0 & 0.2 & 28.1 & 16.7 & 2.3 & 2.6 & 17.5 & 82.7 & 2.8 & & 25.6 & 8.7 & 5.7 & 125.2 \\
\hline
\end{tabular}

\section{Sources and Notes:}

aoil (except fuel oil and crude) and wood from industrial consumption statistics 5 with the electric sector and petroleum refining subtracted out on the basis of 1975 coefficients. 5 Bagasse from Table 17 of this report. Electricity from Long. 2

bTotal consumption from Reference 7 quoted in Long. ${ }^{2}$ Transportation assumed to consume all remaining gasoline, additional consumption assumed to be gas oil.

CFrom fuel mix tables (Section ). Hydro from Table 17 of this report (fossil fuel equiv.).

EGas oil is leftover. Electricity from Long. 2

fapproximately $1.1 \times 10^{15}$ joules of oil are used by Falconbridge (the ferronickel enterprise) in the generation of electricity sold to the public utility. 
(2.7 $\times 1015$ joules) appears to be from this source. Unfortunately, since captive generation and purchase of electricity from the public utilities are not separated in the industrial consumption statistics, total energy use by industrial category cannot be estimated accurately. In addition there are a number of inconsistencies between the estimates in Table 19 and figures reported el sewhere (see notes to table). Nonetheless some tentative generalities can be made.

TABLE 19

INDUSTRIAL ENERGY CONSUMPTION, 1975

(joules $\times 10^{12}$ )

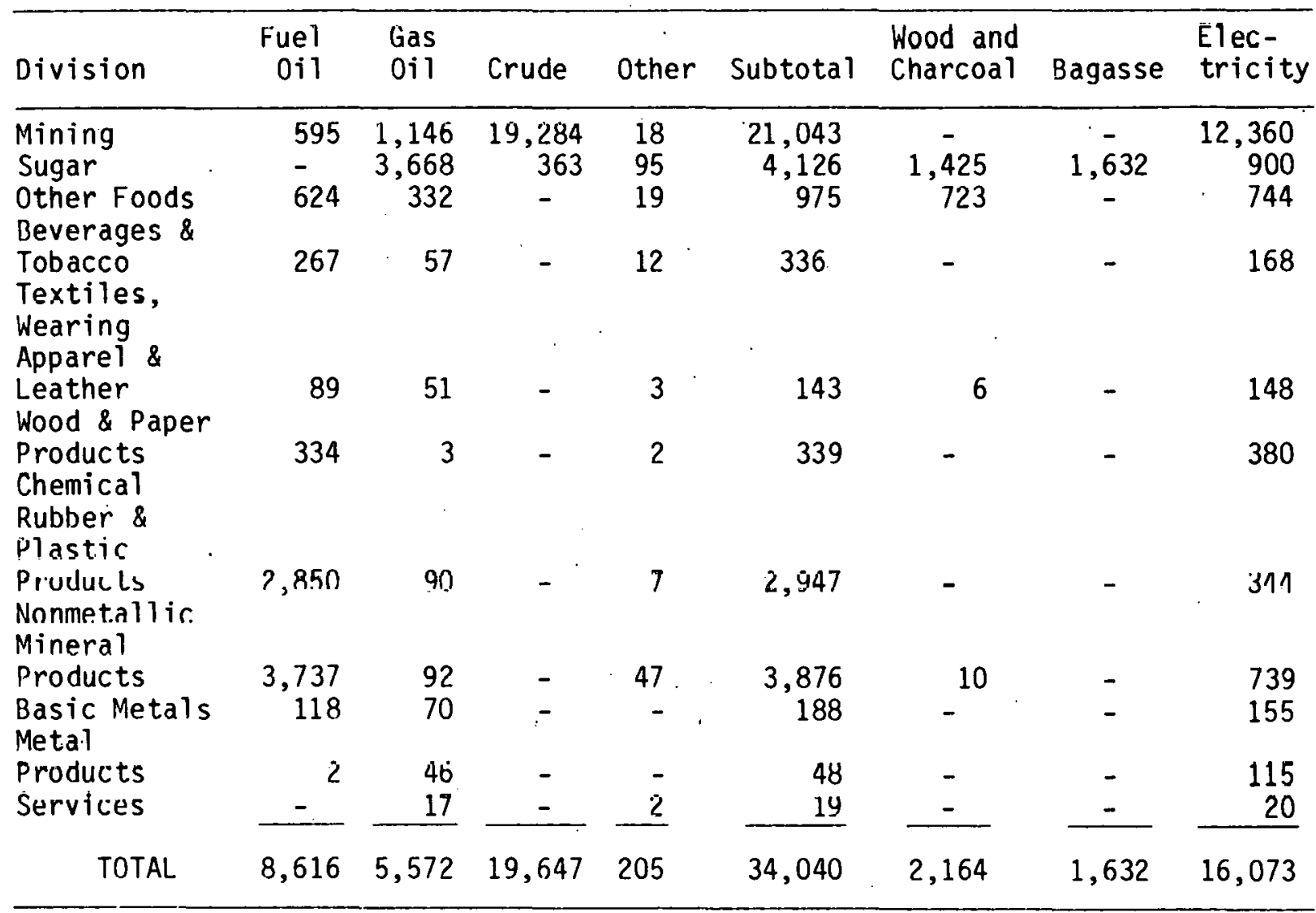

Source: Reference 5 .

Note: Does not include electricity or petroleum industries (which were inconsistent with estimates in Reference 2). Electricity consumption (valued here at fossil fuel equivalent) appears to include captive generation and therefore fuel uses cannot be totaled. Bagasse consumption quoted here is less than unle tenth of that quoted in Reference 2. The reason for this discrepancy is unknown. 
The four largest industrial energy consuming categories [mining, food processing (including sugar), chemical, and nonmetallic mineral products] appear to account for almost 97 percent of industrial oil consumption and virtually all of the industrial consumption of the biomass fuels. Within the mining sector, most of the energy is consumed by the Falconbridge nickel enterprise which uses all of the crude oil allocated to the mining sector in Table 19. Estimates of the Falconbridge energy consumption in 1977 are shown in Table 20. The soft market for nickel combined with rising oil prices has led to production cutbacks, and Falconbridge is currently selling some of its excess electricity to the public utility, CDE. Since nickel is one of the Dominican Republic's major exports, its dependence on $0 i 1$ is of particular concern.

Sugar processing, the next largest industrial energy consuming category, accounted for 12 percent of the industrial oil consumption and almost all of the biomass consumption in 1975. [It should be noted that the bagasse consumption given in Table 19 is less than 10 percent of the consumption reported in Long ${ }^{2}$ for the Consejo Estatal de Azucar (C.E.A.), the government's sugar processing enterprise]. The manufacturing of nonmetallic mineral products, whose energy consumption is dominated by the cement industry, accounted for approximately 9 percent of industrial oil consumption followed by the chemical industries with an additional 9 percent.

TABLE 20

PRODUCTION AND ENERGY CONSUMPTION DATA FOR FALCONBRIDGE (1977)

Input Dry Ore (metric tonnes)

Production (metric tonnes of nickel)

$\begin{array}{ll}\text { Diesel } 0 i 1 & \begin{array}{l}\text { Liters } \\ \text { Energy (GJ) }\end{array} \\ \text { Bunker } C & \text { Liters } \\ \text { Energy (GJ) }\end{array}$

Electricity sold to $\operatorname{CDE}(\mathrm{GJ})$

Total Energy Consumption (GJ)

Specific Energy Consumption
$2.28 \times 10^{6}$

24,898

$8.886 \times 10^{6}$

358,996

$230 \times 10^{6}$

$9,618,307$

$-3,456$

$9,973,847$

or
$400.5 \mathrm{GJ} /$ tonne nickel $160.2 \mathrm{GJ} /$ tonne product

Source: T.V. Long. ${ }^{2}$ 


\subsubsection{Transportation}

A recent study of transportation in the Dominican Republic 1 by Delcanda International Ltd. estimated that approximately $18 \times 1015$ joules of petroleum products were consumed by the transportation sector in 1977. (This estimate does not include sea, air, or rail, however, for which very little information appears to be available.) As illustrated in Table 21, approximately 26 percent of this total was consumed by private cars, 25 percent by taxis, 13 percent by motorcycles, 2 percent by buses, and 34 percent by trucks (including jeeps). The division between passenger and freight transportation is not clear since the trucks, which are mostly small, carry passengers as well as goods and there is no direct information on freight movement. It would appear however, that at least two thirds of the fuel was used for passenger transportation.

The vehicle fleet has been growing at over 10 percent a year since 1972 (see Tabie 22) in spite of the oil price increases and high automobile import taxes. By 1977 there were approximately 37 vehicles for every 1000 people compared to 26 in 1972. A detailed breakdown of the types of vehicles operating in 1977 is given in Table 23. Private automobiles are shown to be the most numerous vehicle with approximately one for every 15 families. A disproportionate number of these vehicles operate in Santo Domingo where about three quarters of the private cars are registered and the majority of taxis are located.

The efficiencies of the various transportation modes have not been estimated accurately, which makes it difficult to analyze the transportation sector in detail. There is some concern that the publicos (fixed route taxis) are operating inefficiently. An odd-even system (allowing only half of the fleet to operate on any given day) was developed in Santo Domingo in order to ensure high passenger loads and to prevent the publicos from causing congestion and inefficiency in the alternative transportation modes. Suggestions have also been made to shift the publicos, which are now small cars, over to minibuses or to attempt to shift the ridership to buses, 10 but the information necessary to evaluate the energy impact with such shifts is lacking. Longll uses two procedures to estimate the efficiency of the publicos. The first procedure, based on hypothetical, budget figures, yields an estimate of 63 to 75 passenger kilometers per gallon while the second, using an assumed vehicle efficiency of 20 to 25 kilometer's per gallon and a load factor of 4.6 (taken from a passenger occupancy study), estimates an efficiency of 92 to 115 passenger kilometers per gallon. The uncertainty implied by the 50 percent variation between these estimates combined with even greater uncertainty concerning the effects of the publicos on the efficiencies of the other transportation modes makes it virtually impossible to draw any definitive conclusions regarding the energy savings of shifts away from the use of publicos.

Another area in which information appears to be lacking is air, ship, and train transportation. Although only $0.2 \times 10^{15}$ joules of aviation fuel were imported in 1977 (apparently most of the planes fuel elsewhere), it is possible that significant quantities of reported kerosine/avtur use are destined to airplanes. The rail system transported roughly ten million tons of freight (mostly sugarcane) in 1976 which, given the relatively small travel distances in the Dominican Republic, is unlikely to have consumed a significant quantity of fuel. The DELCANDA study estimated that the railways could be expanded along selected routes to attract an average of 20 percent of the loads cur- 
rently being carried by truck. Since rail transport tends to be more energy efficient than truck transport, the recent oil price increases have made such extensions more economically attractive and rail transport could become a significant transportation mode in the future.

Within the international shipping sector approximately 3.5 million metric tons of merchandise were unloaded into the Dominican Republic and 2.5 million on loaded (with less than one percent in both cases by Dominican ships). Coastal shipping is almost insignificant with approximately 135,000 tons shipped in 1976. As in the case of railways, this could become a more important mode of transport in the future.

TABLE 21

GROUND TRANSPORTATION FUEL CONSUMPTION BY VEHICLE TYPE

\begin{tabular}{lcc}
\hline Vehicle Type & Joules $\times 10^{15}$ & Percentage \\
\hline Private Automobile & 4.8 & 26 \\
Collective Taxis & 4.6 & 25 \\
Jeeps & 0.5 & 3 \\
Small Trucks & 3.5 & 19 \\
Trucks & 2.2 & 12 \\
Buses & 0.4 & 2 \\
Motorcycles & 2.4 & 13 \\
Total & 18.3 & 100
\end{tabular}

Source: Reference 7 quioted in Long. 2

Note: Aviation fuel accounts for an additional $2 \times 10^{15}$ joules.

TABLE 22

NUMBER OF REGISTERED MOTOR VEHICLES

\begin{tabular}{|c|c|c|c|c|c|c|c|}
\hline $\begin{array}{l}\text { Vehicle } \\
\text { Type }\end{array}$ & 72 & 73 & 74 & 75 & 76 & 77 & $\begin{array}{c}\text { Average } \\
\text { Growth Rate } \\
\text { (\%/annum) }\end{array}$ \\
\hline \multirow[t]{2}{*}{$\begin{array}{l}\text { Automobile } \\
\text { Trucks } \\
\text { Buses } \\
\text { Other }\end{array}$} & $\begin{array}{r}48,7.36 \\
22,117 \\
1,332 \\
41,215 \\
\end{array}$ & $\begin{array}{r}54,657 \\
25,496 \\
1,485 \\
47,755 \\
\end{array}$ & $\begin{array}{r}62,687 \\
29,397 \\
1,587 \\
49,006 \\
\end{array}$ & $\begin{array}{r}69.687 \\
29.678 \\
1,633 \\
54,693 \\
\end{array}$ & $\begin{array}{r}74,563 \\
33,680 \\
2,010 \\
59,864 \\
\end{array}$ & $\begin{array}{r}80,800 \\
36,500 \\
2,500 \\
65,000 \\
\end{array}$ & $\begin{array}{r}10.6 \\
10.5 \\
13.4 \\
9.5 \\
\end{array}$ \\
\hline & 113,400 & 129,393 & 142,677 & 155,691 & 170,117 & 184,800 & 10.3 \\
\hline
\end{tabular}

Source: Reference 2. 
TABLE 23

OPERATING MOTOR VEHICLES (1977)

\begin{tabular}{lr}
\hline Vehicle Type & Number \\
\hline Private Cars & 56,715 \\
Taxis (Intraurban) & 18,563 \\
Taxis (Interurban) & 7,403 \\
Dump Trucks & 2,760 \\
Flatbed and Small Trucks & 34,609 \\
Small Farm Trucks & 1,010 \\
Jeeps & 2,280 \\
Motorized Small Wagons & 1,085 \\
Muluriycies & 20,991 \\
Heavy Equipment & 7,151 \\
Buses (Interurban) & 731 \\
Buses (Intraurban) & 801 \\
Buses (Private) & 779
\end{tabular}

Source: Association Dominicana de Choferes Unidos; information obtained from the Ministrada por Rentas Internas, through Long. 2

\subsubsection{Residential}

The use of fuels for domestic purposes is dominated by cooking and lighting requirements. The fuels used are primarily LPG, electricity, and charcoal in urban areas and wood and charcoal in rural areas (with small amounts of kerosine used in both areas). The residential fuel use figures quoted here are based largely on a national household expenditure survey carried out in 1976-77. Because of uncertainties in the fuel prices and in the proportion of wood and electricity purchased commercially, the resulting estimates are tentative. A household energy use survey being carried out by PCI should allow more definitive estimates to be derived.

The total fuel consumption of the residential sector is estimated at 20.3 quadrillion joules of which approximately 38 percent is wood, 28 percent is charcoal, 12 percent is LPG, 11 percent is kerosine and 10 percent is electricity. The use of fuels for cooking in urban and rural areas is summarized in Table 24 (with an explanation of terms in Appendix B). As illustrated in this table, while wood and charcoal account for approximately 78 percent of the total fuel use (D), the relatively low efficiencies $\left(e_{j}\right)$ of wood and charcoal devices imply that they satisfy only 61 percent $\left(f_{j}\right)$ of the cooking requirements. The differences in the fuel shares between urban and rural households are striking. In the rural areas wood supplies about one half the cooking requirements, charcoal 28 percent, kerosene 17 percent, and LPG the remainder. In the urban areas the situation is reversed with LPG being the most important (60 percent) and wood and kerosene being almost insignificant.

The household lighting fuel estimates are shown in Table 25 . It was assumed that all households which did not purchase electricity from the public utility used kerosine for lighting. Using a "reasonable" value for lighting 
energy requirements this procedure accounts for all kerosine sales not allocated to cooking. It is likely, however, that a significant number of households receive electricity without charge (either in company housing or by tapping the electric lines) or use other fuels for lighting. Public utility electricity consumption (besides lighting) is shown in Table 26. Approximately 1.8 quadrillion joules of electricity are consumed by electric appliances. Among the upper income groups a large portion of this electricity probably goes to water heating and air conditioning and possibly some electric cooking.

TABLE 24

TENTATIVE FUEL MIX TABLE

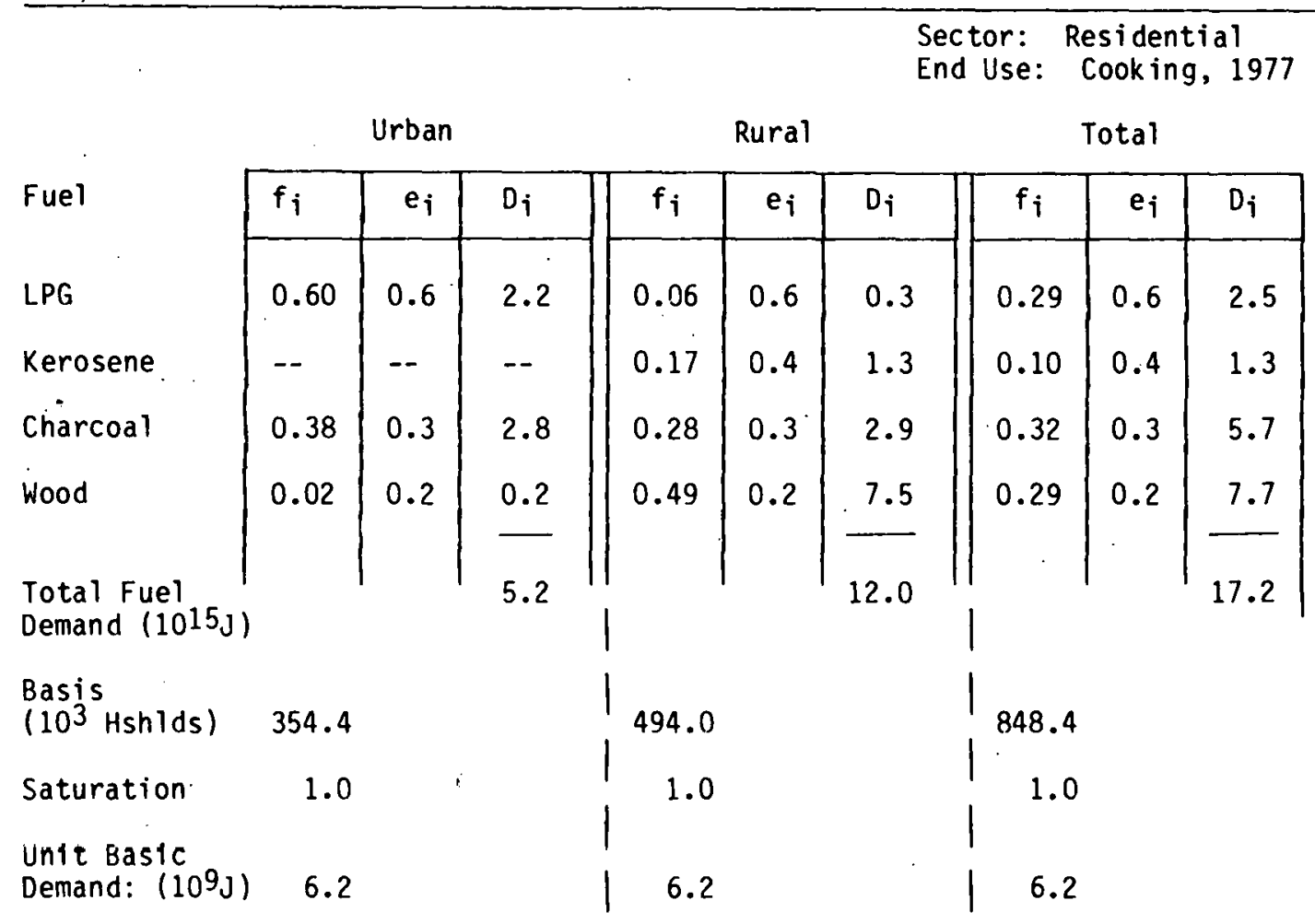

Notes: See Tables 34 and 35. 
TABLE 25

TENTATIVE FUEL MIX TABLE

Sector: Residential

End Use: Lighting, 1977

\begin{tabular}{|c|c|c|c|c|c|c|c|c|c|}
\hline \multirow[b]{2}{*}{ Fuel } & \multicolumn{3}{|c|}{ Urban } & \multicolumn{3}{|c|}{ Rural } & \multicolumn{3}{|c|}{ Total } \\
\hline & $f_{i}$ & $\mathbf{e}_{\mathbf{j}}$ & $D_{i}$ & $f_{i}$ & $\mathbf{e}_{\mathbf{i}}$ & $D_{i}$ & $f_{i}$ & $e_{i}$ & $D_{\mathbf{i}}$ \\
\hline Electricity & 0.68 & 1 & 0.11 & 0.08 & 1 & .02 & 0.34 & 1 & 0.13 \\
\hline Kerosene & 0.32 & $0.2 b$ & $0 . \ddot{2}$ & 0.92 & 0.25 & 0.8 & 0.66 & 0.25 & 1.0 \\
\hline $\begin{array}{l}\text { Total ruél } \\
\text { Demand }\left(10^{15} \mathrm{~J}\right)\end{array}$ & & & 0.31 & & & 0.82 & & & 1.13 \\
\hline $\begin{array}{l}\text { Basjs } \\
\left(10^{3} \text { Hshlds }\right)\end{array}$ & 354.4 & & & 494.0 & & & 848.4 & & \\
\hline Saturation & 1.0 & & & 1.0 & & & 1. & & \\
\hline $\begin{array}{l}\text { Unit Basic } \\
\text { Demand: }\left(10^{9} \mathrm{~J}\right)\end{array}$ & 0.4 & & & 0.4 & & & 0.6 & & \\
\hline
\end{tabular}

Notes: See Tables 36 and 37 .

TABLE 26

TENTATIVE FUEL MIX TABLE

Sector: Residential

End Use: Appliances, 1977

\begin{tabular}{|c|c|c|c|c|c|c|c|c|c|}
\hline \multirow[b]{2}{*}{ Fuel } & \multicolumn{3}{|c|}{ Urban } & \multicolumn{3}{|c|}{ Rural } & \multicolumn{3}{|c|}{ Total } \\
\hline & $\mathbf{f}_{\mathbf{i}}$ & $e_{i}$ & $D_{i}$ & $f_{i}$ & $\mathbf{e}_{\mathbf{j}}$ & $D_{1}$ & $f_{i}$ & $\mathbf{e}_{\mathbf{j}}$ & $D_{i}$ \\
\hline Electricity & 0.68 & 1.0 & 1.69 & 0.08 & 1.0 & 0.28 & 0.33 & 1.0 & 1.97 \\
\hline $\begin{array}{l}\text { Total Fuel } \\
\text { Uemand }\left(10^{15} \mathrm{~J}\right)\end{array}$ & & & 1.69 & & & 0.28 & & & 1.97 \\
\hline $\begin{array}{l}\text { Basis } \\
\left(10^{3} \text { Hshlds }\right)\end{array}$ & 354.4 & & & 494.0 & & & 848.4 & & \\
\hline Saturation & 0.6 & & & 0.0 & & & 0.3 & & \\
\hline $\begin{array}{l}\text { Unit Basic } \\
\text { Demand: }(109 \mathrm{~J})\end{array}$ & 7.0 & & & 7.0 & & & 7.0 & & \\
\hline
\end{tabular}

Notes: See Tables 38 and 39. 


\subsubsection{The Electric Sector 13}

In 1977 the nominal capacity of the Corporaccion Dominicana de Electricidad (the public utility) system was $638 \mathrm{MWe}$. Table 27 shows the breakdown by type of plant. Approximately $506 \mathrm{MWe}$ of this total was effective capacity with $263 \mathrm{MWe}$ in base load plants. For the same year, the gross energy inputs to the CDE system were approximately $5.1 \times 10^{15}$ joules of oil-based fuels and $2.8 \times 10^{15}$ joules of hydro (in fossil fuel equivalent), accounting for about 2000 GWh (7.3 $\times 10^{15}$ joules) of on-line electricity generation. In addition, about $1.1 \times 10^{15}$ joules of oil-based fuels and a small amount of bagasse were used in the industrial sector to generate approximately 84 GWh $\left(0.3 \times 10^{15}\right.$ joules) sold to CDE. With total CDE electricity sales of slightly more than $1.5 \times 10^{9}$ GWh $\left(5.5 \times 10^{15}\right.$ joules), implying transmission and distribution losses of 27 percent, the net energy consumption of the electric sector (defined to include all electricity sold by $C D E$ ) was about $23.4 \times 10^{15}$ joules. Historical electricity generation and sales data are given in Table 28.

In the past few years the CDE has encountered a number of problems which have led to an inefficient use of the existing energy resources and an inability to supply the (connected) load. Hydroelectric generation has been beset by problems arising from competing water requirements and the lack of an adequate procedure for allocating the existing water resources between irrigation and hydroelectric generation. Installation delays and the breakdown of existing facilities exacerbated the supply shortages in the system, already short of base load capacity. In addition, the transmission and distribution losses have been increasing (see Table 28) and are far in excess of what could be considered normal. While part of these losses are attributed to theft, which has apparently been increasing rapidly with the increasing electricity prices, the transmission and distribution system is reportedly in poor condi-

'TABLE 27

CDE NOMINAL CAPACITY 1977

$\left(M W_{e}\right)$

\begin{tabular}{lrr}
\hline Plant Type & $\begin{array}{c}\text { Capacity } \\
(\text { MWe })\end{array}$ & $\begin{array}{r}\text { Share } \\
(\%)\end{array}$ \\
\hline Steam & 336.3 & 53 \\
Diese & 23.4 & 4 \\
Hydro & 149.5 & 23 \\
Gas Turbine & 98.6 & 15 \\
& $\overline{637.8}$ & $\overline{100}$
\end{tabular}

Source: References 2 and 3.

Note: aIncludes the Tavera and Valdesia facilities from which the CDE "purchases" electricity. 
TABLE 28

CDE ELECTRICITY GENERATION (ON LINE), PURCHASES, AND SALES (GWh)

\begin{tabular}{|c|c|c|c|c|c|c|c|c|}
\hline Plant Type & 70 & 71 & 72 & 73 & 74 & 75 & 76 & 77 \\
\hline $\begin{array}{l}\text { Steam } \\
\text { Diese } \\
\text { Gas Turbine } \\
\text { CDE Hydro } \\
\text { Purchased Hydro } \\
\text { Other Purchases } \\
\end{array}$ & $\begin{array}{r}773.9 \\
8.0 \\
-- \\
82.0 \\
-- \\
8.6 \\
\end{array}$ & $\begin{array}{r}920.0 \\
5.6 \\
-- \\
67.0 \\
-- \\
8.1 \\
\end{array}$ & $\begin{array}{c}1046.2 \\
13.8 \\
-- \\
71.5 \\
-- \\
6.9 \\
\end{array}$ & $\begin{array}{r}1115.4 \\
22.2 \\
-- \\
59.1 \\
123.3 \\
6.0 \\
\end{array}$ & $\begin{array}{r}969.9 \\
20.4 \\
267.7 \\
68.2^{a} \\
119.7 \\
1.6 \\
\end{array}$ & $\begin{array}{r}890.3 \\
30.0 \\
461.6 \\
53.5 \\
106.6 \\
2.4 \\
\end{array}$ & $\begin{array}{r}1003.1 \\
17.0 \\
295.4 \\
76.7 \\
(224) \mathrm{b} \\
31.3 \\
\end{array}$ & $\begin{array}{r}1514.1 \\
8.7 \\
280.0 \\
59.8 \\
(171)^{b} \\
83.9 \\
\end{array}$ \\
\hline Generation & 871.5 & 1000.9 & 1138.4 & 1326.0 & 1447.5 & 154 & 1647.5 & 2117.5 \\
\hline & $\underline{684.4}$ & 772.5 & 873.2 & 1023.1 & 1097.0 & 1170.7 & 1207.9 & 1535.4 \\
\hline Losses & 21 & 23 & 23 & 23 & 24 & 24 & 27 & 27 \\
\hline
\end{tabular}

Source: T.V. Long, The Rational Use of Energy in the Dominican Republic, report to the Inter-American Development Bank, 22 May 1979; and M.J. Perez, Caracteristicas generales de las demanda y la oferta de energia, in CODIA 50.

Notes: TThere were discrepancies within M.J. Perez's report on the value of this figure. The estimate consistent with total generation was chosen here al though it is not consistent with Table 11 of this report.

bThese figures were estimated from the total hydro resource use quoted in Roberto Liz et al., Evaluacion de la Situacion Energetica Nacional, Santo Domingo, July 1978.

tion.15 Finally, the generation efficiency of approximately 26 percent for the thermal plants is low, though this may be in part the result of using peaking plants for base load generation. With the net energy requirements of the CDE electric sector already accounting for almost 19 percent of total energy use in 1977 (see Table 18) and with CDE electricity sales growing at 12 percent a year (between 1970 and 1977), the inefficiencies in the electricity generation and delivery are of particular concern.

In addition to the electricity sales of the CDE, captive electricity generation within the industrial sector is apparantly a widespread phenomenon. Unfortunately, there is very little documentation on the installed capacity and electricity generation with in the industrial sector, 16 al though recent generator sales datal7 provide evidence that captive generation has been increasing rapidly in recent years, presumably the result of the frequent outages of the COE system and the electricity price increases. 


\section{ENERGY CONSUMPTION PATTERNS}

NOTES AND REFERENCES

1. World Bank, Dominican Republic, Its Main Economic Development Problems, 1978.

2. T. V.-Long, The Rational Use of Energy in the Dominican Republic, report to the Inter-American Development Bank, 22 May 1979.

3. Roberto Liz et al., Evaluacion de la Situation Energetica National, Banco Central de la Republica Dominicana, Santo Domingo, 1978.

4. FAO, Yearbook of Forest Products, 1977.

5. Oficina Nacional de Estadistica, Estadistica Industrial de la Republica Dominica, 1975, Santo Domingo, 1975.

6. Oficina Nacional de Estadistica, unpubl ished material.

7. DELCANDA International Ltd., Technical-Economic Study of the Transport Sector, report to the Interamerican Development Bank, Dominican Republic, JuTy 1978.

8. The population was approximately $4.98 \mathrm{million}$ in 1977 , and $4.3 \mathrm{mill}$ ion in 1972 (Reference 1, above).

9. T. V. Long, op. cit.

10. The first suggestion was made in Reference 7 above, the second in Reference 9.

11. T. V. Long, op. cit.

12. Figures from Oficia Nacional de Estadistica; Republica Dominica en Cifras, 1978.

13. It should be noted that there are a number of discrepancies in the electricity generation and capacity estimates from different sources which do not appear to be the result of different accounting procedures. For example, the electricity generation of the Tavera hydroelectric plants in 1975 is estimated at 225 and 93 million $\mathrm{kWh}$ in the Statistical Data Book of the USAID Mission to the Dominican Republic and M. J. Perez, Caracteristicas generales de las demanda y la oferta de energia, respectively. Similar discrepancies exist between other reports.

14. The capacity figures quoted here are from: T. V. Long, The Rational Use of Energy in the Dominican Republic and Roberto Liz et al., Evaluacion de Ta situacion Energetica National.

15. T. V. Long, ibid.

16. An estimate of the captive generation is given in section 3.2 .1 of this report. As noted, however, this estimate is very tentative. 


\section{ENERGY CONSUMPTION PATTERNS}

\section{NOTES AND REFERENCES (continued)}

17. The "emergency" generator sales between 1973 and 1977 (quoted in Roberto Liz et al., Evaluacion de la situacion Energetica National, July 1978) were for 624 plants with a total capacity of over $100 \mathrm{MW}_{\mathrm{e}}$, equivalent to approximately 20 percent of the effective capacity of the CDE system. 


\section{FUTURE ENERGY OUTLOOK}

Any assessment of energy resource and technology options requires the projection of energy requirements at least 20 years into the future - the time required to implement any large-scale changes in the energy supply system. Ideally, such projections should provide a realistic view of the future economic and demographic situation of the country and should include a detailed analysis of the energy implications of the economic growth, the structural changes in the economy, the urban/rural population split, the resulting transportation requirements, and a number of other energy-relevant characteristics. In this overview, however, we have limited the projection to a macro-assessment of the future energy situation with the aim of providing reasonable scenarios from which general conclusions can be drawn.

In these projections the demand for commerciall and noncommercial fuels (i.e., wood, charcoal, and other biomass fuel) are assessed separately. The procedures and results of these projections are discussed in this section; the assumptions which were used in deriving the commercial demand projection parameters are given in Appendix B.

\subsection{COMMERCIAL ENERGY DEMAND PROJECTIONS}

The technique used to project the total commercial energy requirements to 1990 and 2000 is based on an assumed relationship between energy demand and economic growth and energy prices. This relationship is defined by the following equation:

$$
D(t)=D(0)\left[\frac{\operatorname{GDP}(t)}{\operatorname{GDP}(0)}\right]^{\mathrm{IE}} \quad\left[\frac{\operatorname{PEN}(t)}{\operatorname{PEN}(0)}\right]^{P E}
$$

where:

$$
\begin{aligned}
D & =\text { commercial energy demand, } \\
G D P & =\text { gross domestic product in constant } \$, \\
P E N & =\text { average real price of del ivered energy, } \\
I E & =\text { income elasticity of commercial energy demand, } \\
P E & =\text { price elasticity of commercial energy demand, } \\
(0) & =\text { base year, } \\
(t) & =\text { year } t .
\end{aligned}
$$

Since very little is known about price elasticities (especially in the long term) or the effect of rising energy costs on economic growth, projecting energy demand for a twenty year period is largely a matter of guesswork. The lack of data necessary to estimate income elasticities specific to the Dominican Republic further increases the level of uncertainty. With this in mind, we have developed alternative scenarios which indicate the order of magnitude of the range of uncertainty. The price effect is not incorporated in the Reference Case scenario which is developed first, primarily to provide a "business as usual" projection from which to work. To provide the sectoral breakdown and fuel mix of commercial energy demand in the Reference Case, exogenous projections of the residential and transportation fuel demand are employed (also derived under "business as usual" conditions), the "other" sector share and fuel mix are assumed to remain constant, and assumptions are made regarding the future fuel mix of the industrial sector and the level of 
hydro utilization and overall efficiency of the electric sector. The sectoral shares and fuel demands of the electric and industrial sectors are implicit in these estimates and can be determined simultaneously.

A second case is then developed by incorporating an assumed growth rate in energy prices and a price elasticity for commercial energy demand. The sectoral shares and fuel mix are from the Reference Case, except that the absolute level of hydro-generation remains constant. While in practice the price elasticities of energy demand would be expected to vary between sectors and between fuels, the available data are not capable of supporting a disaggregated analysis. 2

The resulting commercial energy demand estimates for 1990 and 2000 are presented by sector and fuel type in Tables 29 to 31 . In the Reference Case, total commercial energy demand is projected to grow from $85.2 \times 10^{15}$ joules in 1977 to $228.1 \times 10^{15}$ joules in 1990 and to $486.5 \times 10^{15}$ joules in the year 2000. Alternatively, in Case 2, the commercial energy demand grows to $195.7 \times$ $10^{15}$ joules in 1990 and $371.2 \times 10^{15}$ joules in 2000 .

In both scenarios the sectoral shares of energy demand change significantly over this time period. The electric sector whose net energy demand share was 27 percent in 1977 accounts for 34 percent in the year 2000. While this represents a relatively large share of commercial energy use, the implicit annual growth rates for the electric sector of approximately 8.9 percent in the Reference Case and 7.6 percent in Case 2 are well below the electric sector growth rates projected on the basis of historical data (electricity sales grew at about 12 percent a year between 1970 and 1977). The shares of the industrial sector in final energy demand remain approximately constant, the principal change occurring in the fuel mix which is assumed to shift towards a

TARLE 29

COMMERC IAL ENERGY DEMAND - 1977

(1015 joules)

\begin{tabular}{|c|c|c|c|c|c|}
\hline $\begin{array}{l}\text { Fue? } \\
\text { Sector }\end{array}$ & Uil & Hydróa & tlecertctzy & $\begin{array}{l}\text { Total } \\
\text { Uirect Use }\end{array}$ & $\begin{array}{c}\text { Share } \\
(\%)\end{array}$ \\
\hline $\begin{array}{l}\text { Transportation } \\
\text { Residential } \\
\text { Industrial } \\
\text { Electric Sector } \\
\text { Other }\end{array}$ & $\begin{array}{r}18.5 \\
4.8 \\
31.3 \\
26.2 \\
1.6 \\
\end{array}$ & $\begin{array}{l}-- \\
-- \\
-- \\
2.8 \\
= \\
\end{array}$ & $\begin{array}{c}-- \\
2.1 \\
2.1 \\
(-5.6) \\
1.4 \\
\end{array}$ & $\begin{array}{r}18.5 \\
6.9 \\
33.4 \\
23.4^{\mathrm{C}} \\
3.0 \\
\end{array}$ & $\begin{array}{r}22 \\
8 \\
39 \\
27 \\
4 \\
\end{array}$ \\
\hline Resource Use & 82.4 & 2.8 & -- & 85.2 & 100 \\
\hline 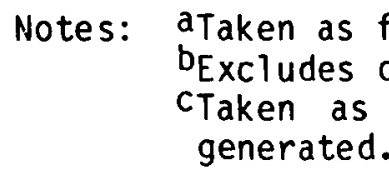 & $\begin{array}{l}\text { fossil } \\
\text { oil ref } \\
\text { total } \\
\text {. }\end{array}$ & $\begin{array}{l}\text { del equiva } \\
\text { ning losse } \\
\text { resources }\end{array}$ & $\begin{array}{l}\text { lent. } \\
\text { s. } \\
\text { consumed by }\end{array}$ & utilities less & electricity \\
\hline
\end{tabular}


greater proportion of electricity. The shares of the residential and transportation sectors both fall slightly, with electricity also playing a greater role in the residential sector.

The national oil requirements, perhaps the most important aspect of the Dominican Republic's future energy situation, are shown to increase from 82.4 $\times 10^{15}$ joules in 1977 to $218.7 \times 10^{15}$ joules in 1990 and to $462.5 \times 10^{15}$ joules in 2000 in the Reference Case, implying an annual growth rate of 7.8 percent. Even in Case 2, oil use increases to $347.2 \times 10^{15}$ joules in the year 2000 , growing at an annual rate of 6.3 percent.

\subsection{NONCOMMERCIAL ENERGY PROJECTIONS}

At present, there is no standard or systematic way of projecting the consumption of noncommercial fuels, or of animal and human energy. The projection procedure adopted below is no more than an exercise in extrapolation using the best available information.

TABLE 30

COMMERCIAL ENERGY DEMAND PROJECTION - REFERENCE CASE (1015 joules)

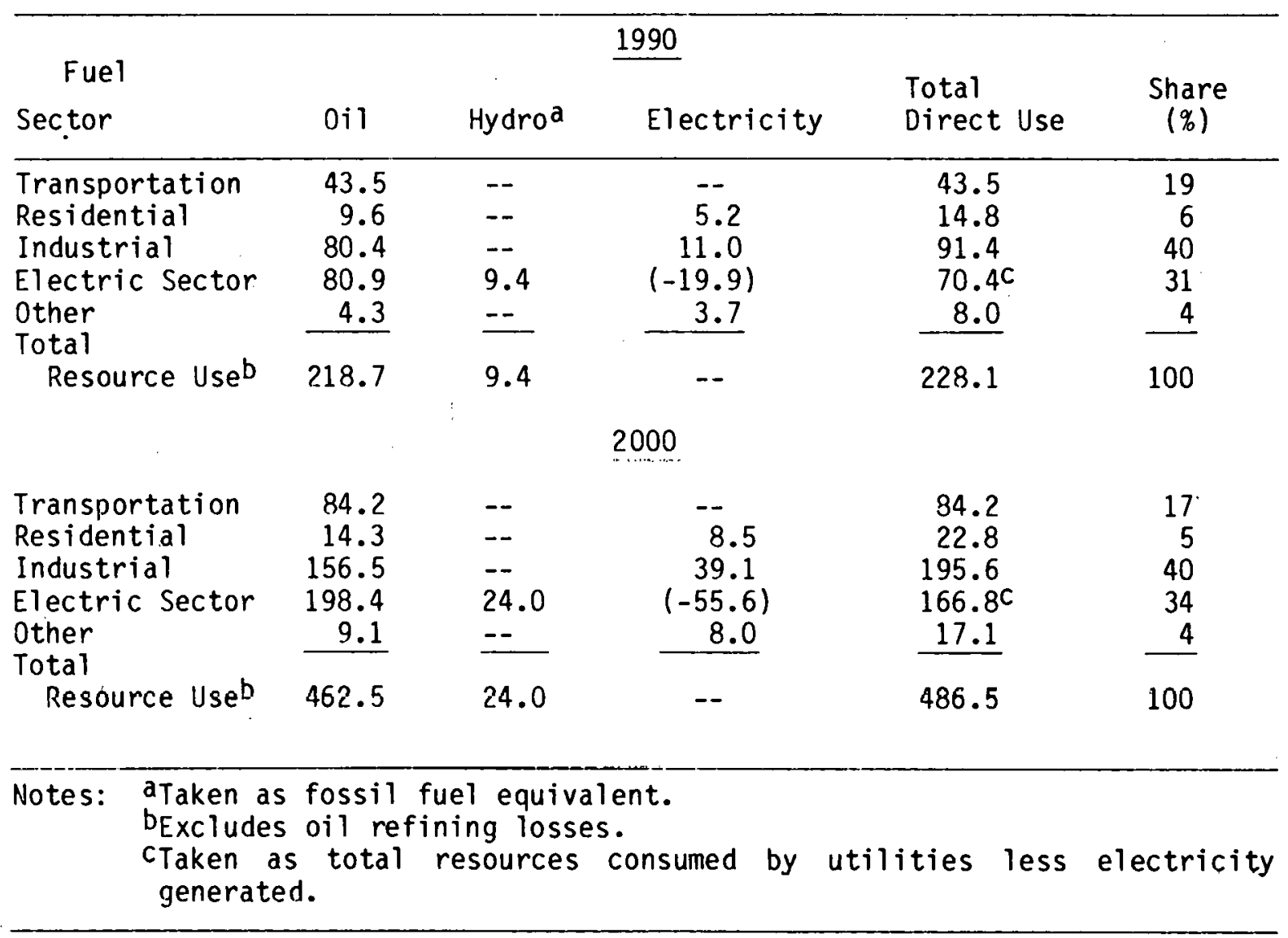


TABLE 31

COMMERCIAL ENERGY DEMAND PROJECTION - CASE 2 (1015 joules)

\begin{tabular}{|c|c|c|c|c|c|}
\hline \multicolumn{6}{|c|}{1990} \\
\hline Sector & $0 i 1$ & Hydroa & Electricity & $\begin{array}{c}\text { Total } \\
\text { Direct Use }\end{array}$ & $\begin{array}{c}\text { Share } \\
(\%)\end{array}$ \\
\hline \multirow{2}{*}{$\begin{array}{l}\text { Transportation } \\
\text { Residential } \\
\text { Industrial } \\
\text { Electric Sector } \\
\text { Other } \\
\text { Total } \\
\quad \text { Resource Useb }\end{array}$} & $\begin{array}{r}37.3 \\
8.2 \\
69.0 \\
68.1 \\
3.7 \\
\end{array}$ & $\begin{array}{l}-- \\
=- \\
-- \\
9.4 \\
=-\end{array}$ & $\begin{array}{r}-- \\
4.5 \\
9.4 \\
(-1.7 .1) \\
3.2 \\
\end{array}$ & $\begin{array}{c}37.3 \\
12.7 \\
78.4 \\
60.4 \mathrm{C} \\
6.9 \\
\end{array}$ & $\begin{array}{r}19 \\
6 \\
40 \\
31 \\
4 \\
\end{array}$ \\
\hline & 186.3 & 0.4 & -- & 195.7 & 100 \\
\hline \multicolumn{6}{|c|}{2000} \\
\hline \multirow{2}{*}{$\begin{array}{l}\text { Transportation } \\
\text { Residential } \\
\text { Industrial } \\
\text { Electric Sector } \\
\text { Other } \\
\text { Total } \\
\quad \text { Resource Useb }\end{array}$} & $\begin{array}{r}64.3 \\
10.9 \\
119.4 \\
145.7 \\
6.9 \\
\end{array}$ & $\begin{array}{l}-- \\
-- \\
-- \\
24.0 \\
-- \\
\end{array}$ & $\begin{array}{r}-- \\
6.5 \\
29.8 \\
(-42.4) \\
6.1 \\
\end{array}$ & $\begin{array}{r}64.3 \\
17.4 \\
149.2 \\
127.3 \mathrm{C} \\
13.0 \\
\end{array}$ & $\begin{array}{r}17 \\
5 \\
40 \\
34 \\
4 \\
\end{array}$ \\
\hline & 347.2 & 24.0 & -- & 371.2 & 100 \\
\hline \multicolumn{6}{|c|}{$\begin{array}{l}\text { Notes: aTaken as fossil fuel equivalent. } \\
\text { bExcludes oil refining losses. } \\
\text { cTaken as total resources consumed by utilities less electricity } \\
\text { generater. }\end{array}$} \\
\hline
\end{tabular}

Two of the major noncommercial fuels, wood and charcoal, are used mainly for cooking in both the urban and rural areas with a small amount going to industrial areas. If we assume that consumption of noncommercial ruels in the urban sector and in industry will remain constant (in absolute terms) to the year 2000, any increase in the consumption of wood and charcoal will occur in the rural sector. In 1977 , the rural pupulation of the DR was about $2.68 \mathrm{mil}=$ lion (see Section 1.0) and in the year 2000 the United Nations 3 has projected that it. will be about 4.34 million. This is in effect an average annual growth rate of 2.1 percent. for the rural population during the period 19772000. In 1977, the rural population used $12.0 \times 1015$ joules of fuel energy for cooking - of which 62 percent came from wood, 24 percent from charcoal, 11 percent from kerosine, and 3 percent from LPG. If we assume that the relative shares of wood, charcoal, kerosine, and LPG in 2000 will be similar to those in 1.977 and if we assume the implied 2.1 percent growth rate for the rural population, then the noncommercial energy requirements for rural cooking in 2000 will be about $16.7 \times 1015$ joules from wood and charcoal combined (see Table 35). Combining this with the urban household and industrial use of wood and charcoal yields a total of $20.7 \times 10^{15}$ joules. 
The energy content of available crop residues, with the exception of bagasse, amounted to $10.1 \times 10^{15}$ joules in 1977 (see Table 15). If the growth rate of 2.1 percent (the average of the growth of major crops) is used to project total energy that may be obtained from crop residues, apart from bagasse, then this energy source could provide almost $16.3 \times 10^{15}$ joules in 2000 . In 1977, production of bagasse amounted to 3,899 metric tons, with energy content ranging from 27 to $43 \times 10^{15}$ joules depending on the energy coefficient chosen (see Table 15). If we assume that bagasse production will increase at an average annual rate of 3.5 percent (the rate projected by SEA for sugarcane production during the period 1976-1986), 4 then in 2000. the energy that could be supplied by bagasse would be in the range of 59 to $94 \times 10^{15}$ joules.

The energy content of available animal dung was about $48 \times 10^{15}$ joules in 1971 (see Table 16). Based on the country's average annual growth rate ( 3 percent) of livestock between 1961 and 1975 as reported in the United Nations Statistical Yearbook, 5 animal dung, used either as cooking fuel or fertilizer, could contribute about $113 \times 10^{15}$ joules to the energy needs of the rural population in the year 2000.

In 1975 there were about 3.1 million 6 draft animals (cattle, horses, donkeys, mules) which consumed about 134,568 tons of corn, 10,136 tons of sweet potato, and 8,624 tons of cassava as feed. 7 When the calorie value of these different feeds is taken into account, total food energy intake amounts to about $1908.4 \times 10^{6}$ joules. If consumption of these feeds (assuming no change in caloric value) grows at the same rate (3 percent) that is projected for livestock, then in the year 2000 draft animals can be expected to consume the equivalent of $3995.6 \times 10^{6}$ joules of feedstuffs. If we assume, as Revelle 9 does, that energy utilized in animal work is about 40 percent of the food energy intake of draft animals, then in 2000 these animals could provide almost $1598 \times 10^{6}$ joules of useful energy. 


\section{FUTURE ENERGY OUTLOOK}

NOTES

1. The term "commercial" energy generally refers to energy forms normally actively traded in developed country markets such as oil, gas, coal, and electricity. The primary categories of "noncommercial" energy are wood, agricultural wastes, and animal dung. The term "noncommercial" is in fact a misnomer, since there are monetary markets for these fuels. In some contexts, the term must be extended to include human and animal power. Other terms sometimes used for "noncommercial" are "traditional," "primitive" (vs "modern") or "nonconventional" (vs "conventional").

2. An attempt to estimate fuel and sector specific price and income elasticities from the available data in the Dominican Republic is given in T. V. Long, The Rational Use of Energy in the Dominican Republic.

3. United Nations, Trends and Prospects in Urban and Rural Population. 1950-2000 as assessed in 1973-74, p. 35, ESA/P/WP.54, Aprit 25, 1975.

4. Secretaria De Estado De Agriculture, Diagnostico y Estrategia Del Desarrol10 Agropecuario 1976-1986, p. 130.

5. United Nations, 1976 Statistical Yearbook, p. 116, New York, 1977.

6. United Nations, 1976 Statistical Yearbook.

7. Secretaria De Estado De Agricultura, Plan Operativo 1978, Anexo 1, Table 1.2.

8. The 1968 caloric values for corn (3.60 per gram), sweet potato $(0.892$ per gram), and cassava (1.08 per gram) were taken from "Hoja de Balance de Al imentos para la Republica Dominicana," No. 8, p. 8, Oflctna Nactunal De Estadistica, 1971.

9. Revelle, Roger, Requirements for energy in the rural areas of developing countries, in Norman L. Brown (Ed.), Renewable Energy Resources and Rural Applications in the Developing World, p. 13, Westview Press, BouTder, Coloradn, 1978. 


\section{OBSERVATIONS AND CONCLUSIONS}

In this preliminary assessment of energy supply and demand, a number of areas have been identified which will have an important effect on the future role of energy in meeting the Dominican Republic's developmental goals. The key concern is undoubtedly the role of imported petroleum. Others include the need for more complete and systematic data and information on potential domestic energy resources and on the underlying determinants of future energy demand in various sectors of the nation's economy.

In the context of developing economies, the demand for energy arises from the essential role energy performs in raising productivity and contributing to growth and development as well as in meeting basic needs such as cooking and lighting. The "business-as-usual" scenario we have projected for energy demand in the Dominican Republic takes into account current and projected demographic patterns as well as identified industrial and agricultural trends and policies. Under this scenario, total energy consumption is projected to rise to about $590 \times 10^{15}$ joules in the year 2000. Taking current domestic energy resource development trends into consideration, 82 percent of this demand will have to be met with imported oil. This implies a level of imports of about 215,000 barrels per day which, even at a very conservative estimate of $\$ 50 /$ barrel in 2000, will mean an import bill of almost 4 billion dollars a year. It is clear that even with optimistic projections of future sugar exports and prices, this level of imports will be very difficult to maintain.

Increasing energy system utilization efficiency to provide the same levels of service with smaller amounts of fuel use is clearly an important priority. However, the information base on which a future scenario of efficiency improvements could be determined at the sectoral and subsectoral level is lacking. Indeed, ever current sectoral energy consumption levels need a great deal of further documentation, especially in the industrial sector where the data base is poor. Losses in electrical transmission and distribution are very high for the small size of the DR integrated grid and the need for improvements here have been commented on by other observers. 1 Our projections include significant reductions in transmission and distribution losses from a current level of approximately 27 percent down to 17 percent by 2000 .

Projections of future energy consumption from the inadequate data base that currently exists are, no doubt, subject to many uncertainties. Projections by other observers, particularly at the sectoral level, are also subject to problems of intersectoral consistency especially as they use sectoral income elasticities on the basis of scanty and unreliable data. A systematic process of data collection efforts on current and historical levels of energy use in different sectors should be a priority task.

The known domestic energy resources of the DR are inadequate to support levels of projected development. However, efforts to $p l a n$ their rational. utilization, given the oil situation, need priority. Hydro power, especially, has not been properly utilized so far. The fact that of the $136 \mathrm{MW}$ of installed capacity only about $40 \mathrm{MW}$ is currently available because of releases of water for irrigation suggests that considerable strengthening of planning capability is needed in the water resources sector. The known levels of deforestation suggest that percent levels of noncommercial fuels in use are already approaching their natural sustainable limits. The potential use of peat and lignite deposits needs further investigation. 
Finally, energy use in the food system is virtually undocumented in the DR. Preliminary estimates are provided in Appendix $C$, but the high level of uncertainty limits their usefulness. (These estimates were not used in earlier portions of the assessment partly because of conflicts with the data used in other demand sectors.) Supplying the basic food requirements of the growing population is obviously of principal importance and, while the agricultural sector is not a large energy consumer at present, increasing crop production under severe land constraints is generally a fairly energyintensive process. Future stages of this study should provide insights into the role of energy in the food system within the context of the country's energy situation as a whole. 
OBSERVATIONS AND CONCLUSIONS

\section{NOTES AND REFERENCES}

1. For example, T. V. Long, The Rational Use of Energy in the Dominican Republic, report to the Inter-American Development Bank, 22 May 1979. 


\section{APPENDIX A}

\section{DOMINICAN REPUBLIC REFERENCE ENERGY SYSTEM}

The Reference Energy System (RES) presented in this appendix represents an integrated picture of the energy supply-demand pattern in the Dominican Republic. It consists of the estimated energy demands by specific end use described in Chapters 3 and 4 , energy conversion technology, fuel mixes, and, ultimately, resources used to satisfy these demands. Associated with each energy flow or branch in the RES network is a series of coefficients of three types: efficiency, environmental, and economic. At present, only a limited set of efficiencies and flows have been developed for the Dominican Republic. An expanded and computerized version of this RES can be used for evaluating the energy system impacts of policy (conservation, fuel substitution, pricing, etc.) and technoloqical options.* The reference energy systems for 1977 and 2000 , presented in this appendix do not incorporate any significant changes in the energy supply system's structure.

*For a more detailed description of the RES approach to energy systems analysis, one may refer to: An Analytical Framework for the Assessment of Energy Resource and Technology Options, BNL-50800, Feb. 1978. 


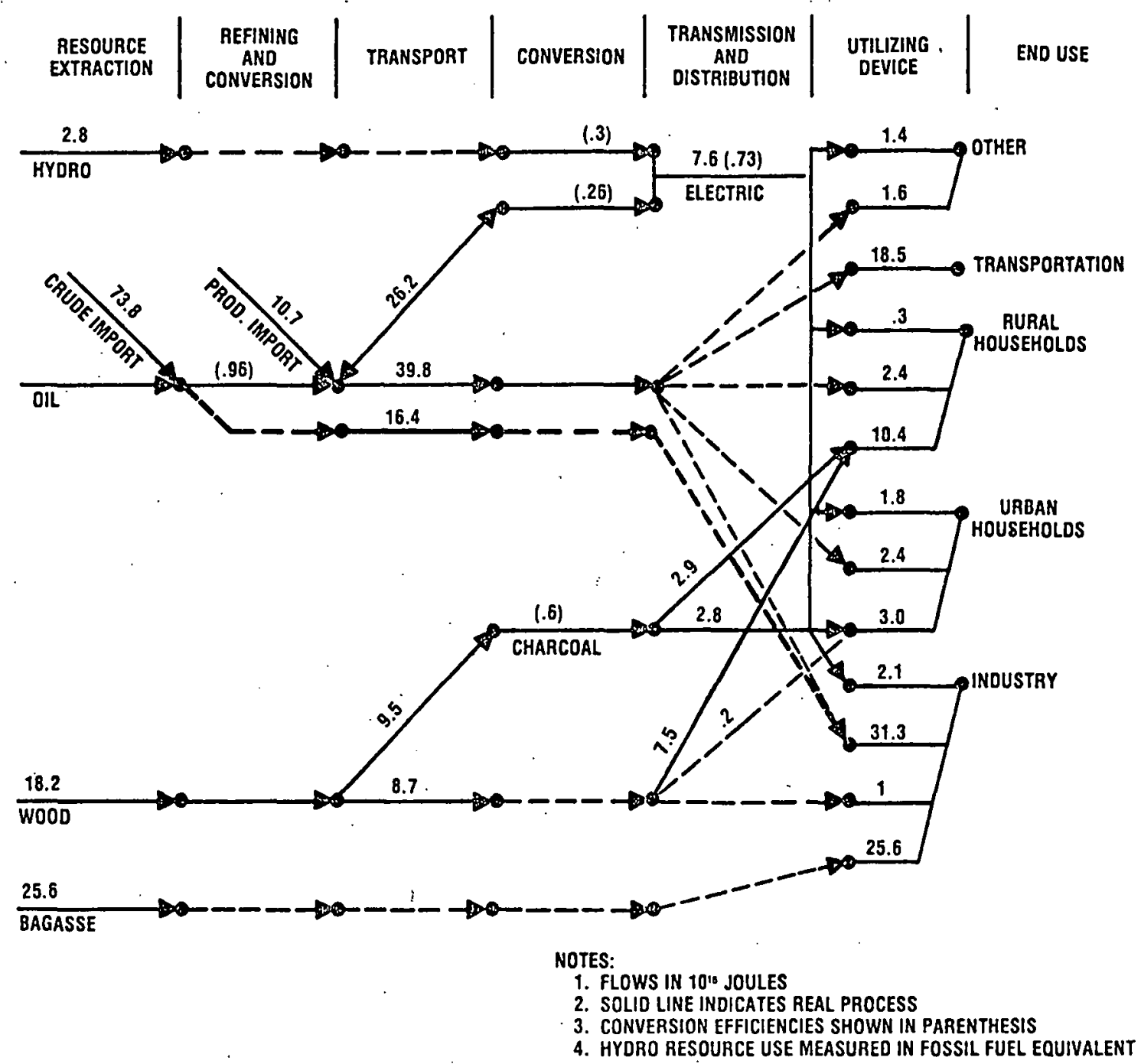

Figure 2. Dominican Republic Reference Energy System (1977) 

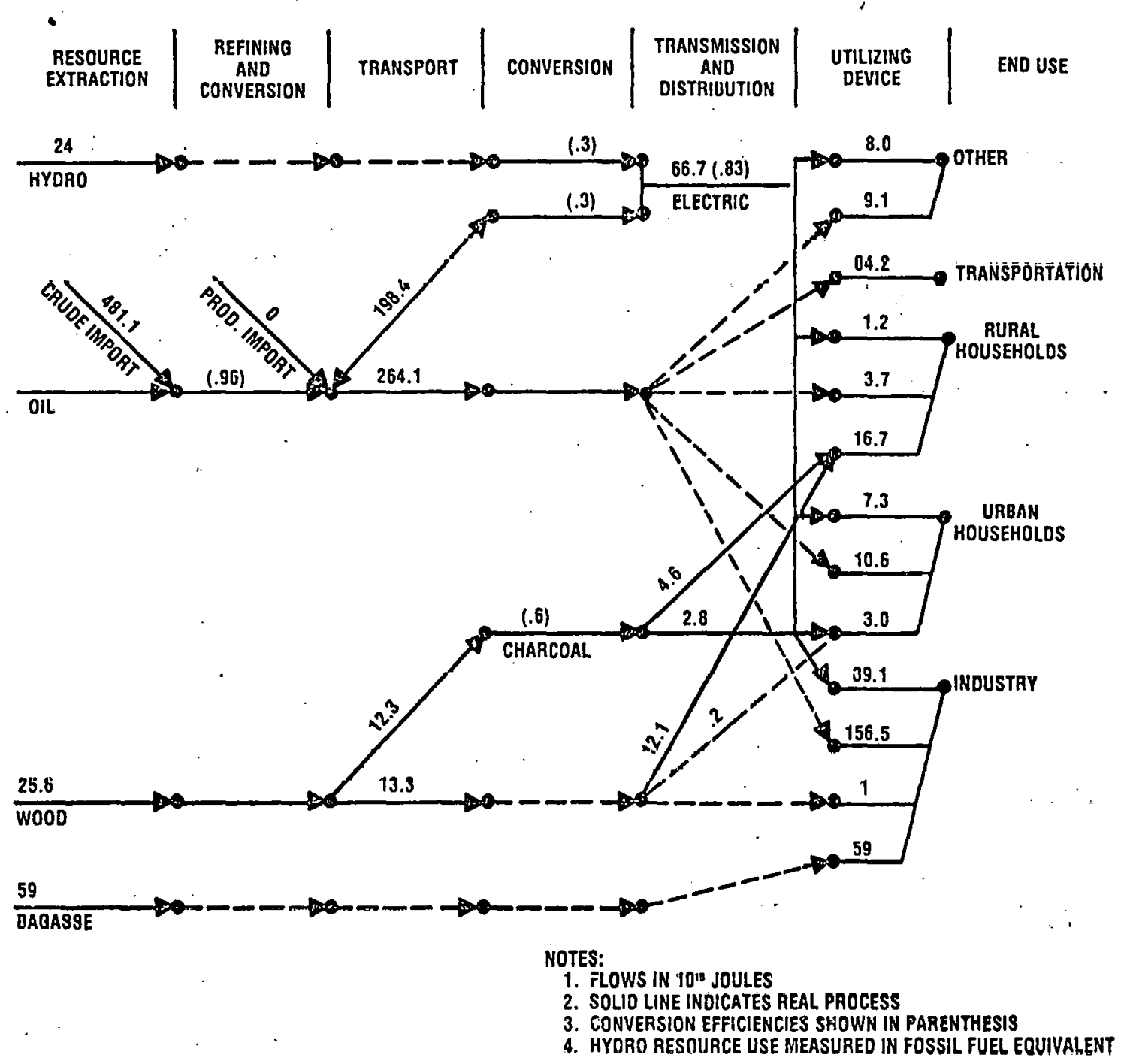

Figure 3. Dominican Republic Reference Energy System -.... $(2000)=$ Reference Case 


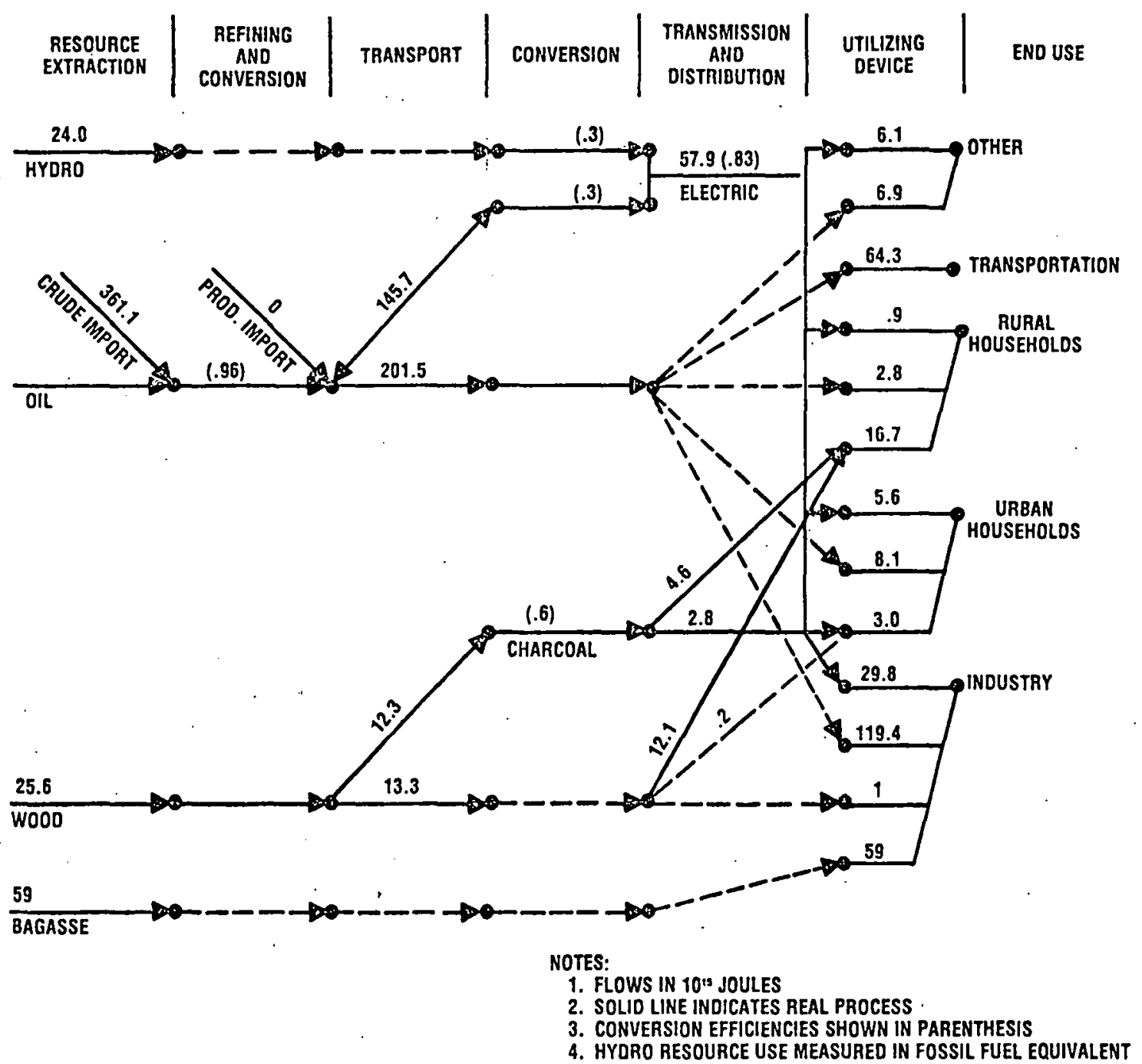

Figure 4. Dominican Republic Reference Energy System (2000) - Case 2 


\section{APPENDIX B}

\section{COMMERCIAL ENERGY PROJECTION ASSUMPTIONS}

The assumed values of the parameters employed in the projection of total commercial energy demand are given in Table 32 . Table 33 lists the assumptions which provided the basis for estimating the sectoral breakdown and fuel mix in the Reference Case. For Case 2 the sector shares and fuel mix were assumed equal to the Reference Case except that the level of hydro utilization was kept at the same absolute level. Finally, Tables 34-39 describe in detail the assumptions and results of the Reference Case residential projection.

TABLE 32

COMMERCIAL ENERGY DEMAND PROJECTION ASSUMPTIONS

\begin{tabular}{lcc}
\hline Parameter & $\begin{array}{c}\text { Reference Case } \\
1977-2000\end{array}$ & $\begin{array}{c}\text { Scenario 2 } \\
1977-2000\end{array}$ \\
\hline Income Elasticitya & 1.3 & 1.3 \\
Price Elasticityb & -- & -0.3 \\
Annual GDP Growth Rate (real)c & $6 \%$ & $6 \%$ \\
Annual Energy Price Growth Rate (rea) & -- & $4 \%$
\end{tabular}

afrom A. Lambertini, Energy and Petroleum in Non-OPEC Developing Countries, 1974-1980, World Bank Staff Working Paper No. 224, February 1975. For a discussion of income elasticities of energy demand see $P$. F. Palmedo et al., Energy Needs, Uses and Resources in Developing Countries, BNL 50784, March 1978.

DFrom World Bank Development Policy Staff, Prospects for Developing Countries, 1978-85, November 1977.

CApproximate average annual growth rate of real GDP, 1960-77. See World Bank, Dominican Republic: Its Main Economic Development Problems, December 1978. 
TABLE 33

ASSUMPTIONS FOR REFERENCE CASE

SECTORAL BREAKDOWN OF COMMERC IAL ENERGY DEMAND

1. The Residential shares and fuel mix are based on the Fuel Mix Tables described below.

2. The Transportation share is based on the projections derived in the Delcanda Study, Technical-Economic Study of the Transport Sector, Dominican Republic, July 1978.

3. The other sector share and fuel mix are assumed to remain constant to the year 2000 .

4. The industrial sector fuel mix is assumed to be 12 percent electricity and 88 percent oil-based fuel in 1990 and 20 percent electricity and 80 percent oil-based fuels in the year 2000. (The industrial share is determined simultaneously to the electric sector given assumption 5.)

5. The electric system is assumed to have an overall efficiency of 0.2 in 1990 and 0.25 in the year 2000. By 2000, 80 percent of the identified hydrogeneration potential is realized, 31 percent having been realized by 1990 . 


\section{Residential Energy Demand Reference Case Projections}

The Residential fuel demands are projected with the aid of the fuel mix tables 34 to 39 . The variables in these tables are defined below:

FUEL DEMAND, $D_{i}=$ The quantity of a fuel, $i$, actually consumed in a specific demand category, such as when cooking or lighting.

TOTAL FUEL DEMAND, $D=$ The total fuel required to satisfy the requirements of a specific demand category. Electricity is considered as a fuel in this sense and $D=\Sigma_{i} D_{i}$.

RELATIVE EFFECTIVENESS, $e_{i}=$ The relative effectiveness with which fuel, $i$ is used in a demand category. This parameter depends on the utlization technology employed.

BASIC ENERGY DEMAND, $[$ = The amount of energy that would be required in a specific demand category, assuming a relative effectiveness, $e_{j}$, of $100 \%$ for each fuel employed. Thus, for a given demand category where quantities of fuels, $D$, are consumed with actual Relative Effectiveness, $e_{i}, E=\Sigma_{j} e_{i} D_{j}$.

DEGREE OF SATURATION, $S=$ The fraction of the potential demand for a particular energy use actually being fulfilled at a given time, for example, if $95 \%$ of all households have refrigerators, and potentially all houses can have one refrigerator, $S=0.95$.

SATURATED BASIC ENERGY DEMAND = The Basic Energy Demand that would exist in a category if there was $100 \%$ saturation, $=E / S$.

UNIT BASIC ENERGY DEMAND = The Basic Energy Demand per household.

FIIF.I. FRACTION, $f=$ Fraction of the Saturated Basic Energy Demand that is satisfied by using the $i$ 'th fuel.

$$
f_{i}=\frac{e_{j} D_{i}}{E / S} \quad \text { and } \quad \sum_{i} f_{i}=S \text {. }
$$

The procedure for developing the fuel mix projection in a given demand category begins with the definition of the base year mix. The equations given above lead to estimates of the basic Energy Demand for each category in the reference year of interest.

The Basic Energy Demand derived in this manner is independent of the fuels employed to satisfy the demand and is projected into the future on the basis outlined in the Fuel Mix Table notes, including any increased saturation that may be postulated. In categories where a unit basic demand is defined, it is used as the basis for the projection and, in most cases, is held constant over all reference years. By specifying the Fuel Fractions, $f_{i}$, and Relative Effectiveness, $e_{j}$, the Fuel Demands, $D_{j}$ are derived from the basic energy demands for each future reference year. Thus the fuel mix is defined. 
TABLE 34

TENTATIVE FUEL MIX TABLE

Sector: Residential

End Use: Urban Cooking

\begin{tabular}{|c|c|c|c|c|c|c|c|c|c|}
\hline \multirow[b]{2}{*}{ Fuel } & \multicolumn{3}{|c|}{1977} & \multicolumn{3}{|c|}{1990} & \multicolumn{3}{|c|}{2000} \\
\hline & $f_{i}$ & $e_{i}$ & $D_{i}$ & $f_{i}$ & $e_{i}$ & $D_{i}$ & $f_{i}$ & $e_{i}$ & $D_{i}$ \\
\hline LPG & 0.60 & 0.6 & 2.2 & 0.80 & 0.6 & 6.1 & 0.87 & 0.6 & 10.3 \\
\hline Charcoal & 0.38 & 0.3 & 2.8 & 0.18 & 0.3 & 2.8 & 0.12 & 0.3 & 2.8 \\
\hline Wood & 0.02 & 0.2 & 0.2 & 0.01 & 0.2 & 0.2 & 0.01 & 0.2 & 0.2 \\
\hline $\begin{array}{l}\text { Total Fuel } \\
\text { Demand }\left(10^{15}\right)\end{array}$ & & & 5.2 & & & 9.1 & & & 13.3 \\
\hline $\begin{array}{l}\text { Basis } \\
\left(10^{3} \mathrm{Hsh} 1 \mathrm{ds}\right)\end{array}$ & 354.4 & & & 737 & & & 1,148 & & \\
\hline Saturation & 1.0 & & & 1.0 & & & 1.0 & & \\
\hline $\begin{array}{l}\text { Unit Basic } \\
\text { Demand: }\left(10^{3} \mathrm{~J}\right)\end{array}$ & 6.2 & & & 6.2 & & & 6.2 & & \\
\hline
\end{tabular}

Notes: The 1977 fuel consumption estimates are based on an unpublished survey of household expenditures (Banco Central de la Republica Dominicana, Encuesta de Ingresos y Gastos de las Familias, Mayo 1976 - April 1977) and prices provided by the Banco Central. LPG price was adjusted upward to ensure that household consumption did not exceed total sales. Electric cooking, which could not be separated out from other electricity use, is incorporated in electric appliances.

Projections assume constant Unit Basic Demand and constant wood and charcoal consumption in urban areas to the year 2000 . 
TABLE 35

TENTATIVE FUEL MIX TABLE

Sector: Residential

End Use: Rural Cooking

\begin{tabular}{|c|c|c|c|c|c|c|c|c|c|}
\hline \multirow[b]{2}{*}{ Fuel } & \multicolumn{3}{|c|}{1977} & \multicolumn{3}{|c|}{1990} & \multicolumn{3}{|c|}{2000} \\
\hline & $p_{i}$ & $e_{i}$ & $D_{i}$ & $f_{1}$. & $c_{i}$ & $D_{i}$ & $f_{i}$ & $\mathbf{e}_{\mathbf{i}}$ & $n_{\mathbf{i}}$ \\
\hline LPG & 0.06 & 0.6 & 0.3 & 0.06 & 0.6 & 0.4 & 0.06 & $0 . \overline{6}$ & 0.5 \\
\hline Keroserle & 0.17 & 0.4 & 1.3 & 0.17 & 0.4 & 1.8 & $n .17$ & 0.4 & 2.1 \\
\hline Charcoal & 0.28 & 0.3 & 2.9 & 0.28 & 0.3 & 4.0 & 0.28 & 0.3 & 4.6 \\
\hline Wood & 0.49 & 0.2 & 7.5 & 0.49 & 0.2 & 10.4 & 0.49 & 0.2 & 12.1 \\
\hline $\begin{array}{l}\text { Total Fuel } \\
\text { Demand }\left(10^{15} \mathrm{~J}\right)\end{array}$ & & & 12.0 & & & 16.6 & & & 19.3 \\
\hline $\begin{array}{l}\text { Basis } \\
\left(10^{3} \text { Hshlds }\right)\end{array}$ & 494 & & & 685 & & & 798 & & \\
\hline Saturation & 1.0 & & & 1.0 & & & 1.0 & & \\
\hline $\begin{array}{l}\text { Unit Basic } \\
\text { Demand: }\left(10^{9} \mathrm{~J}\right)\end{array}$ & 6.2 & & & 6.2 & & & 6.2 & & \\
\hline
\end{tabular}

Notes: The 1977 fuel consumption, figures were estimated in a manner similar to that used for urban cooking except that:

1. Wood consumption was adjusted upward to account for the remaining total wood consumption (from Table 17 of this report) after industrial and urban wood and charcual consumption had been allocated.

2. Kerosene was introduced up to the point where the rural unit basic demand equalled the urban unit basic demand.

Projections assume constant shares and constant Unit Basic Demand to the year 2000. 
TABLE 36

TENTATIVE FUEL MIX TABLE

Sector: Residential

End Use: Urban Lighting

\begin{tabular}{|c|c|c|c|c|c|c|c|c|c|}
\hline \multirow[b]{2}{*}{ Fuel } & \multicolumn{3}{|c|}{1977} & \multicolumn{3}{|c|}{1990} & \multicolumn{3}{|c|}{2000} \\
\hline & $f_{i}$ & $\overline{e_{i}}$ & $\mathrm{D}_{\boldsymbol{i}}$ & $f_{i}$ & $e_{i}$ & $D_{i}$ & $f_{i}$ & $e_{i}$ & $D_{i}$ \\
\hline Electricity & 0.68 & 1 & 0.11 & 0.8 & 1 & 0.26 & 0.85 & 1 & 0.43 \\
\hline Kerosene & 0.32 & 0.25 & 0.2 & 0.2 & 0.25 & 0.26 & 0.15 & 0.25 & 0.30 \\
\hline $\begin{array}{l}\text { Total Fuel } \\
\text { Demand }\left(10^{15 \mathrm{~J})}\right.\end{array}$ & & 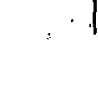 & 0.31 & & & 0.52 & & & 0.73 \\
\hline $\begin{array}{l}\text { Basis } \\
\left(10^{3} \text { Hshlds }\right)\end{array}$ & 354.4 & & . & 737 & & & 1,148 & & \\
\hline Saturation & 1.0 & & & 1.0 & & & 1.0 & & \\
\hline $\begin{array}{l}\text { Unit Basic } \\
\text { Demand: }\left(10^{9} \mathrm{~J}\right)\end{array}$ & 0.44 & & & 0.4 & & & 0.4 & & \\
\hline
\end{tabular}

Notes: For 1977 estimates, the residential electricity consumers were allocated to urban and rural areas in proportion with their expenditures on electricity (from Banco Central de la Republica Dominicana, Encuesta de Ingresos y Gastos de las Familias). All nonelectrified households were assumed to use kerosene for Tighting. The level of kerosene consumption (after accounting for kerosene cooktny) and the efficiency of the kerosene lighting was then used to determine the unit basic demand for lighting. The lighting of electrified households in excess of this unit basic demand was implicitly assigned to electric appliances.

The projections assume $85 \%$ electrification by the year 2000 . 
TABLE 37

TENTATIVE FUEL MIX TABLE

Scctor: Residential.

End Use: Kural Lighting

\begin{tabular}{|c|c|c|c|c|c|c|c|c|c|}
\hline \multirow[b]{2}{*}{ Fuel } & \multicolumn{3}{|c|}{1977} & \multicolumn{3}{|c|}{1990} & \multicolumn{3}{|c|}{2000} \\
\hline & $f_{i}$ & $e_{i}$ & $D_{i}$ & $f_{i}$ & $e_{i}$ & $D_{i}$ & $f_{i}$. & $e_{i}$ & $D_{i}$ \\
\hline Electricity & 0.08 & 1 & 0.02 & 0.15 & 1 & 0.05 & 0.2 & 1 & 0.07 \\
\hline Kerosene & 0.92 & 0.25 & 2.8 & 0.85 & 0.25 & 1.02 & 0.8 & 0.25 & 1.12 \\
\hline $\begin{array}{l}\text { Total Fuel } \\
\text { Demand }(1015 \mathrm{~J})\end{array}$ & & & 4.82 & & & 1.07 & & & 1.19 \\
\hline $\begin{array}{l}\text { Basij } \\
\left(10^{3} \text { Hshlds }\right)\end{array}$ & 494 & & & 685 & & & 798 & & \\
\hline Saturation & 1.0 & & & 1.0 & & & 1. & & \\
\hline $\begin{array}{l}\text { Unit Basic } \\
\text { Demand: }(109 \mathrm{~J})\end{array}$ & 0.44 & & & 0.4 & & & 0. & & \\
\hline
\end{tabular}

Notes: See Table 36. 
TABLE 38

TENTATIVE FUEL MIX TABLE

\begin{tabular}{|c|c|c|c|c|c|c|c|c|c|}
\hline \multirow[b]{2}{*}{ Fuel } & \multicolumn{3}{|c|}{1977} & \multicolumn{3}{|c|}{1990} & \multicolumn{3}{|c|}{$\begin{array}{c}\text { Residential } \\
\text { e: Urban Appliances } \\
2000\end{array}$} \\
\hline & $f_{j}$ & $e_{i}$ & $D_{i}$ & $f_{i}$ & $e_{i}$ & $D_{i}$ & $f_{i}$ & $e_{i}$ & $D_{i}$ \\
\hline $\begin{array}{l}\text { Electricity } \\
\text { Total Fuel } \\
\text { Demand }(1015 \mathrm{~J})\end{array}$ & 0.68 & 1 & $\frac{1.69}{1.69}$ & 0.80 & 1 & $\frac{4.12}{4.12}$ & 0.85 & 1 & $\frac{6.83}{6.83}$ \\
\hline $\begin{array}{l}\text { Basis } \\
\left(10^{3} \text { Hshlds }\right)\end{array}$ & 354.4 & & & 737 & & & 1,148 & & \\
\hline Saturation & 0.6 & & & 0.8 & & & 0.8 & & \\
\hline $\begin{array}{l}\text { Unit Basic } \\
\text { Demand: }\left(10^{9} \mathrm{~J}\right)\end{array}$ & 7.0 & & & 7.0 & & : & 7.0 & & \\
\hline
\end{tabular}

Notes: All urban electricity consumption for 1977 in excess of electric lighting was assigned to appliances. 


\section{TABLE 39}

TENTATIVE FUEL MIX TADLL

Séctor: Residential

End Use: Rurat Appliances

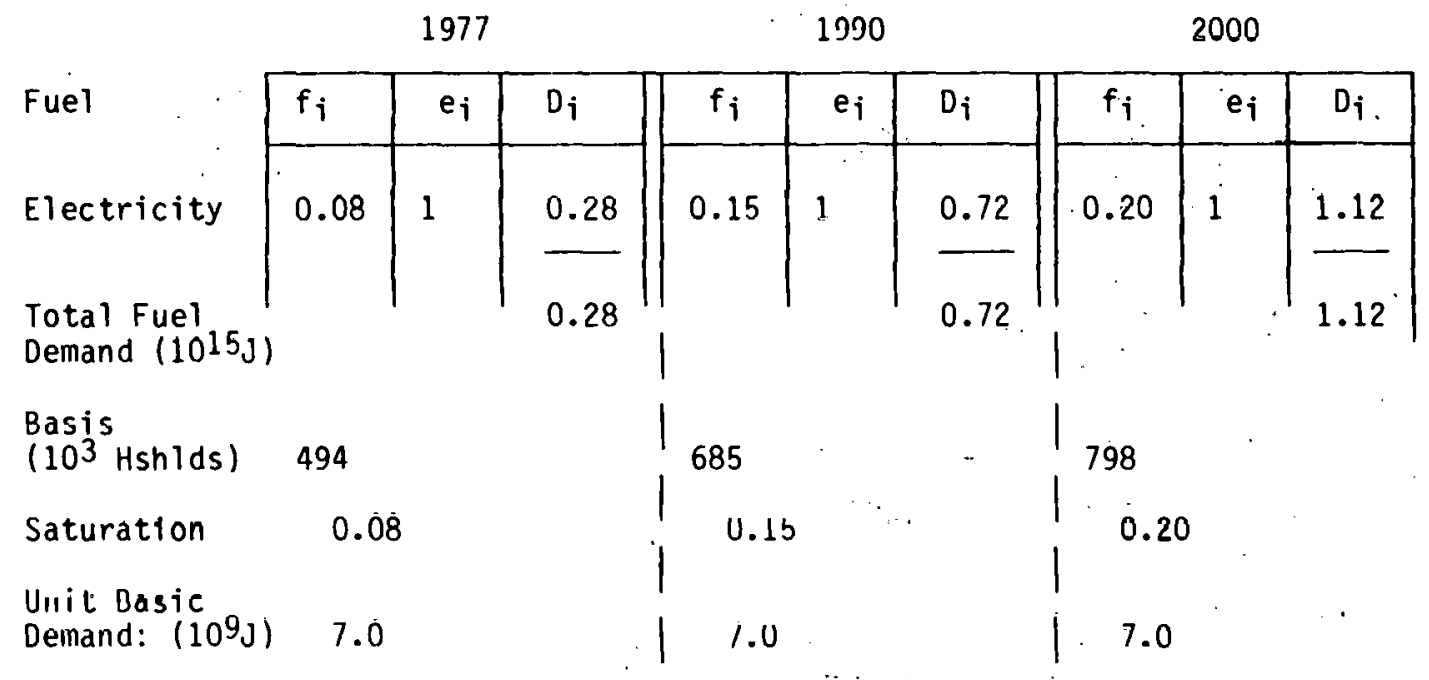

Notes: All 1977 rural electricity consumption in excess of rural electric lighting was assigned to rural appliances. 


\title{
APPENDIX C \\ DOMINICAN REPUBLIC \\ TENTATIVE CROP PROFILES AND ENERGY INPUT ANALYSIS
}

\author{
Prepared By: \\ David Pimentel \\ Cornell University \\ With the Assistance of: \\ Ephraim Back \\ and \\ Eric Garnick \\ Cornell University
}

August, 1979 
As noted in the preface, this assessment will eventually be part of a larger study focusing on the role of energy in the food system. Appendix $C$ provides a very preliminary account of the energy inputs to the production, transportation, and processing of sugarcane and some of the principal food crops. Since no detailed DR data (with the possible exception of fertilizer usage) are available on the energy inputs to the food system, the energy coefficients are, for the most part, based on studies carried out in the United States and elsewhere. Although attempts have been made to adjust the coefficients to account for the different agricultural techniques in the $D R$, the resulting estimates remain very uncertain. Future stages of this study will attempt to eliminate the uncertainties and inconsistencies within the food system through. the use surveys and other forms of data estimation procedures in the field. 


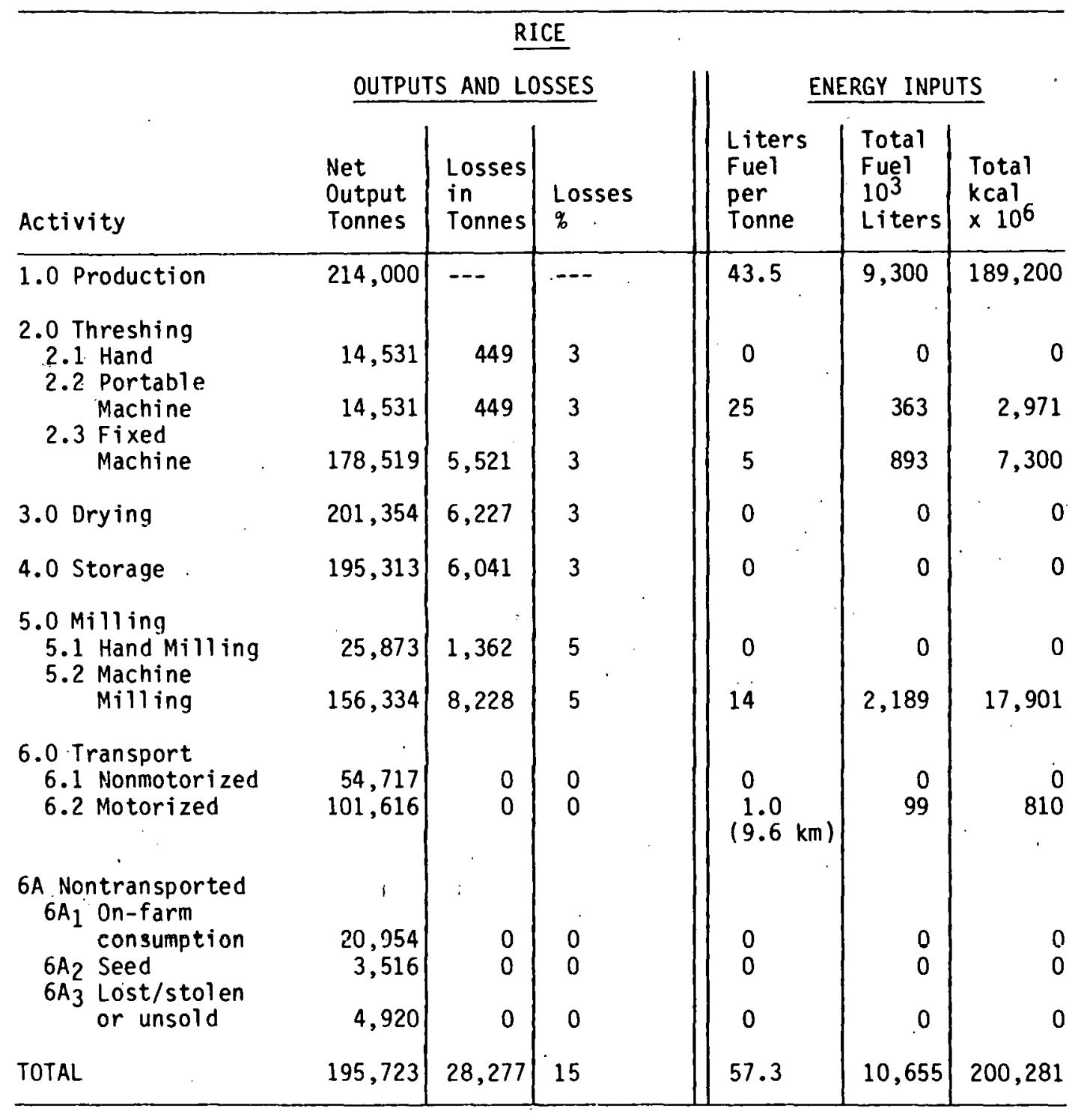




\section{Rice Footnotes}

1.0 Production: See production data sheet. Preharvest losses from:

Cramer, H.H. 1967, Plant Protection and World Crop Production. Crop Protection Advisory Department of

Farbenfabriken Bayer AG, Leuerkusen, p. 106.

Losses due to: insect pests $=3.4 \%$

diseases $\quad=6.4 \%$

weeds $\quad 11.2 \%$

2.0 Threshing: Losses due to threshing from: Nationài Acaderlly of Sclences. 1978. Postharvest Food Losses in Developing Countries, .p. 64. It was assumed that since $86 \%$ nf the tinal crop is marketed (Census SWD\#2B, PRD-CULT-10A), $86 \%$ of the crop was threshed by fixed machine, with the remaining $15 \%$ threshed by either hand or portable machine. The energy inputs for threshing were from the Senegal study, p. $4: 36$.

3.0 Drying: Losses from NAS study p. 64 [see footnote 2.0 ].

4.0 Storage: Losses from NAS study, p. 64.

5.0 Milling: Losses from NAS study, $p .64$. It was assumed that the $14.2 \%$ of the rice crop which is consumed on the farm (Census SWD \#2B, PRD-CULT-10A) is hand milled with the remaining being machine milled. Energy inputs for milling were from the Senegal study.

6.0 Transport: Percentage of motorized vs nonmotorized transport from Census SWD \#5-MRC-CULT-1. Average distance to market of 9.6 $\mathrm{km}$ also from Census SWD\#5-MRC-CULT-1. Energy inputs based upon an average of $830 \mathrm{kcal} /$ tonne $/ \mathrm{km}$ to transport goods by truck (From: D.. Pimentel. Energy used for transporting supplies to the farm, in D. Pimentel (Ed.) 1979, Energy Utilization in Ágriculture, CRC Press, Boca Raton, Fiorida, in press).

The figure of $8,179 \mathrm{kcal} / 1 \mathrm{iter}$ of gasoline is from Tahle C-1: Energy supplies and efficiency, also in the CRC book.

3A Nontransported: Percentages of rice which are not transported from the farm Here ohtinincd from Consus SWD \#28 PRD-CULT-10A. 


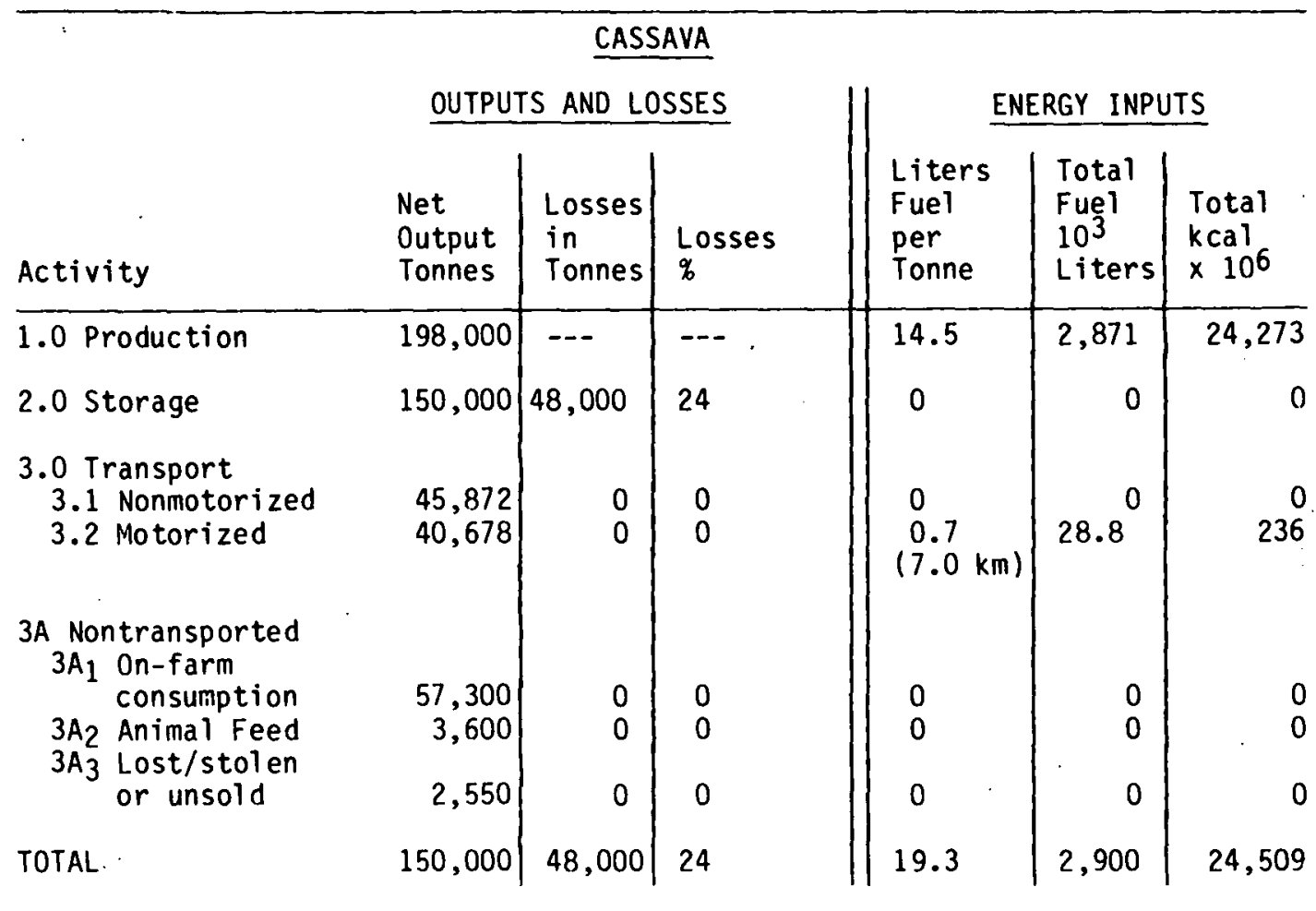

\section{Cassava Footnotes}

1.0 Production: See production data sheet. Pre-harvest losses from: Cramer, H.H., 1967, Plant Protection and World Crop Production. Crop Protection Advisory Department of Farbenfabriken Bayer AG, Leuerkusen, p. 266.

2.0 Storage: Losses; based upon data from Dominican Republic. From: National Academy of Sciences, 1978, Postharvest Food Losses in Developing Countries, p. 112.

3.0 Transport: Percentages of motorized vs nonmotorized transport from Census SWD \#5 MRC-CULT-1. Average distance to market of $7.0 \mathrm{~km}$ al so from Census SWD \#5 MRC-CULT-1. Energy inputs based upon an average of $830 \mathrm{kcal} /$ tonne $/ \mathrm{km}$ to transport goods by tuck (From: D. Pimentel, Energy used for transporting supplies to the farm, in D. Pimentel (Ed.), 1979. Energy Utilization in Agriculture, CRC Press, Boca Raton, Florida, in press).

3A Nontransported: Percentages of cassava which are not transported from the farm were obtained from Census SWD \#2B PRD-CULT-10A. 


\begin{tabular}{|c|c|c|c|c|c|c|}
\hline \multicolumn{7}{|c|}{ BEANS } \\
\hline & \multicolumn{3}{|c|}{ OUTPUTS AND LOSSES } & \multicolumn{3}{|c|}{ ENERGY INPUTS } \\
\hline Activity & $\begin{array}{l}\text { Net } \\
\text { Output } \\
\text { Tonnes }\end{array}$ & $\begin{array}{l}\text { Losses } \\
\text { in } \\
\text { Tonnes }\end{array}$ & $\begin{array}{l}\text { Losses } \\
\%\end{array}$ & $\begin{array}{l}\text { Liters } \\
\text { Fuel } \\
\text { per } \\
\text { Tonne }\end{array}$ & $\begin{array}{l}\text { Total } \\
\text { Fuel } \\
10^{3} \\
\text { Liters }\end{array}$ & $\begin{array}{l}\text { Total } \\
\text { KCal } \\
\times 10^{6}\end{array}$ \\
\hline 1.0 Production & 32,550 & $\ldots$ & -- & 90 & 2,919 & 24,517 \\
\hline 2.0 Storage \& Drying & 22,800 & 9,750 & 30 & 0 & 0 & 0 \\
\hline $\begin{array}{l}\text { 3.0 Transport } \\
3.1 \text { Nonmotorized } \\
3.2 \text { Motorized }\end{array}$ & $\begin{array}{l}8,219 \\
8,219\end{array}$ & $\begin{array}{l}0 \\
0\end{array}$ & $\begin{array}{l}0 \\
0\end{array}$ & $\begin{array}{c}0 \\
1.4 \\
(13.4 \mathrm{kIII})\end{array}$ & $11.1^{0}$ & $\begin{array}{r}0 \\
91\end{array}$ \\
\hline $\begin{array}{l}3 A \text { Nontransported } \\
3 A_{1} \text { On-farm } \\
\text { consumption }\end{array}$ & 4,469 & 0 & 0 & 0 & 0 & \\
\hline $\begin{array}{l}3 A_{2} \text { Animal Feed } \\
3 A_{3} \text { Lost/stolen }\end{array}$ & & 0 & 0 & 0 & 0 & 0 \\
\hline or unsold & 1,003 & 0 & 0 & 0 & 0 & 0 \\
\hline $3 A_{4}$ Seed & 844 & 0 & 0 & 0 & 0 & 0 \\
\hline TOTAL & 22,800 & 9,750 & 43 & 128 & $2,930^{\circ}$ & 24,608 \\
\hline
\end{tabular}

Bean Footnotes

1.0 Production: See production data sheet. Pre-harvest losses from: Cramer, H.H., 1967, Plant Protection and World Crop Production. Crop Protection Advisory Department of Farbenfabriken Bayer $A G$, Leuerkusen, $p .266$.

Losses due to: insect pests $=13.3 \%$

diseases $=11.3 \%$

weeds $\quad=8.7 \%$

2.0 Storage \& Losses based upon data from South and Central American Drying: Countries. From: National Academy of Sciences, 19/8, Postharvest Food Losses in Developing Countries, p. 93.

3.0 Transport: Percentages of motorized vs nonmotorized transport from Census SWD \#5 MRC-CULT-1. Average distance to market of $13.4 \mathrm{~km}$ al so from Census SWD \#5 MRC-CULT-1. Energy inputs based upon an average of $830 \mathrm{kcal} /$ tonne $/ \mathrm{km}$ to tránsport goods by truck: (r ronm: n. Pimentesl, Encrgy used for transporting supplies to the farm, in D. Pimentel (Ed.) 1979. Energy Utilization in Agriculture, CRC. Press, Boca Raton, Florida, in press). The figure of $8,179 \mathrm{kcal} /$ liter of gasoline is from Table C-1: Energy supplies and efficiency, al so in the CRC book.

3A Nontransported: Percentages of beans which are not transported from the farm were obtained from Census SWD \#2B PRD-CULT-10A. 


\begin{tabular}{|c|c|c|c|c|c|c|}
\hline \multicolumn{7}{|c|}{ SUGARCANE } \\
\hline & \multicolumn{3}{|c|}{ OUTPUTS AND LOSSES } & \multicolumn{3}{|c|}{ ENERGY INPUTS } \\
\hline Activity & $\begin{array}{l}\text { Net } \\
\text { Output } \\
\text { Tonnes }\end{array}$ & $\begin{array}{l}\text { Losses } \\
\text { in } \\
\text { Tonnes }\end{array}$ & $\begin{array}{l}\text { Losses } \\
\%\end{array}$ & $\begin{array}{l}\text { Liters } \\
\text { Fuel } \\
\text { per } \\
\text { Tonne }\end{array}$ & $\begin{array}{l}\text { Total } \\
\text { Fuel } \\
10^{3} \\
\text { Liters }\end{array}$ & $\begin{array}{l}\text { Total } \\
\text { kcal } \\
\times 10^{6}\end{array}$ \\
\hline 1.0 Production & 10,740 & --- & --- & 28.7 & 26,069 & 671,294 \\
\hline $\begin{array}{l}\text { 2.0 Transport } \\
2.1 \text { Motorized }\end{array}$ & 10,740 & 0 & 0 & unknown & unknown & unknown \\
\hline $\begin{array}{l}\text { 3.1 Processing } \\
\text { 3.1 Sugar Milling }\end{array}$ & $\begin{array}{r}1,257 \\
290 \\
537 \\
322\end{array}$ & $\begin{array}{l}\text { Sugar } \\
\text { Molasses } \\
\text { Bagasse } \\
\text { Filter }\end{array}$ & ud & 704 & 885,340 & $7,241,179$ \\
\hline TOTAL & $\begin{array}{r}1,257 \\
290 \\
537 \\
322\end{array}$ & $\begin{array}{l}\text { Sugar } \\
\text { Molasses } \\
\text { Bagasse } \\
\text { Filter }\end{array}$ & & $732.7+$ & $36,954+$ & $678,535+$ \\
\hline
\end{tabular}




\section{Sugarcane Footnotes}

1.0 Production: See production data sheet. Pre-harvest losses from: Cramer, H.H., 1967, Plant Protection and World Crop Production. Crop Protection Advisory Department of Farbenfabriken Bayer AG.

2.0 Transport: Assumed that all transpurt of suyarcane is by muturized transport. Average distance to market is unknown, therefore unable to determine energy inputs. Similarly, postharvest losses. are al so unknown.

3.0 Processing: Yield of $117 \mathrm{~kg}$ of refined sugar per tonne of sugarcane from: World Bank Country Study. Dominican Republic, Its Main Economic Development Problems, December 1978.

By-product yields:

$50 \mathrm{~kg}$ surplus Bagasse (at $49 \%$ molsture)/tonne of sugarcane

$27 \mathrm{~kg}$ molasses (89 Brix; sp.gr. 1.47)/tonne of sugarcane

$30 \mathrm{~kg}$ filter mud (at $80 \%$ moisture/tonne of sugarcane

From: Paturau, J.M., 1969, By-Products of the Cane Sugar Industry. El sevier Publishing Company, Amsterdam, London, N.Y., P. 6.

The figures are based upon the following assumptions: sucrose \% case, 13.0; fibre \% cane, 13.0 ; mill extraction, 95\%; overall officioncy, 85\%; purity of mixed juice, 81.0; steam consumption, $500 \mathrm{~kg}$ per tonne of cane; 2.3 tonnes of steam generated per tonne of wet bagasse.

Energy inputs are from: Pimentel, D. and M. Pimentel, 1979, Food, Energy and Society, Edward Arnold Publishers, London, p. 116. They were adjusted for a sugar content of $11.7 \%$. Kcál figures werè converted to liter equivalents based upon a conversiun of $8,179 \mathrm{kcal} / \mathrm{liter}$ of gasuline from Table $C: 1$ Energy supplies and efficiency, in $D$. Pimentel (Ed.) 1979, Energy Utilization in Agriculture. CRC Press, Boca Raton, FTorida (In press). 


\begin{tabular}{|c|c|c|c|c|c|c|}
\hline \multirow[b]{3}{*}{ Activity } & \multicolumn{3}{|c|}{ SWEET POTATO } & & & \\
\hline & \multicolumn{3}{|c|}{ OUTPUTS AND LOSSES } & \multicolumn{3}{|c|}{ ENERGY INPUTS } \\
\hline & $\begin{array}{l}\text { Net } \\
\text { Output } \\
\text { Tonnes }\end{array}$ & $\begin{array}{l}\text { Losses } \\
\text { in } \\
\text { Tonnes }\end{array}$ & $\begin{array}{l}\text { Losses } \\
q\end{array}$ & $\begin{array}{l}\text { Liters } \\
\text { Fuel } \\
\text { per } \\
\text { Tonne }\end{array}$ & $\begin{array}{l}\text { Total } \\
\text { Fuel } \\
10^{3} \\
\text { Liters }\end{array}$ & $\begin{array}{l}\text { Total } \\
\text { kcal } \\
\times \quad 10^{6}\end{array}$ \\
\hline 1.0 Production & 100,000 & -- & $\ldots$ & 11.0 & 1,098 & 9,101 \\
\hline 2.0 Storage & 70,000 & 30,000 & 30 & 0 & 0 & 0 \\
\hline $\begin{array}{l}\text { 3.0 Transport } \\
\text { 3.1 Nonmotorized } \\
\text { 3.2 Motorized }\end{array}$ & $\begin{array}{l}18,930 \\
28,390\end{array}$ & $\begin{array}{l}0 \\
0\end{array}$ & $\begin{array}{l}0 \\
0\end{array}$ & $\begin{array}{l}0 \\
0.75 \\
(7.4 \mathrm{~km})\end{array}$ & $21.3^{0}$ & $\begin{array}{r}0 \\
174\end{array}$ \\
\hline $\begin{array}{l}3 A_{\text {Nontransported }} \\
3 A_{1} \text { On-farm }\end{array}$ & & & & & & \\
\hline $\begin{array}{l}\text { consumption } \\
3 A, \text { Animal Feed }\end{array}$ & $\begin{array}{r}19,460 \\
2,100\end{array}$ & $\begin{array}{l}0 \\
0\end{array}$ & $\begin{array}{l}0 \\
0\end{array}$ & $\begin{array}{l}0 \\
0\end{array}$ & $\begin{array}{l}0 \\
0\end{array}$ & $\begin{array}{l}0 \\
0\end{array}$ \\
\hline or unsold & 1,120 & 0 & 0 & 0 & 0 & 0 \\
\hline TOTAL & 70,000 & 0 & 30 & 16.0 & 1,119 & 9,275 \\
\hline
\end{tabular}

Sweet Potato Footnotes

1.0 Production: See production data sheet. Pre-harvest losses from: Cramer, H.H., 1967, Plant Protection and World Crop Production. Crop Protection Advisory Department of Farbenfabriken Bayer AG, Levierkusen, p. 266.

Losses due to: insect pests $=5.7 \%$

diseases $=15.6 \%$

weeds $\quad=2.9 \%$

2.0 Storage: Losses: based upon data from South and Central American countries and other LDC's. From: National Academy of Sciences, 1978, Postharvesl Fuod Losses in Devcloping Countries, pp. $112-112$.

3.0 Iransport: Percentages of motorized vs. non-motorized transport from Census SWD \#5 MRC-CULT-1. Average distance to market of $7.4 \mathrm{~km}$ al so from Census SWD \#5 MRC-CULT-1. Energy inputs based upon an average of $830 \mathrm{kcal} /$ tonne $/ \mathrm{km}$ to transport goods by tuck (From: D. Pimentel, Energy used for transporting supplles to the farm, in D. Pimentel (Ed.) 1979. Energy Utilization in Agriculture, CRC Press, Boca Raton, Florida, in press). The figure of 8,179 kcal/liter of gasol ine is from Table C-1: Energy supplies and efficiency, also in the CRC book.

3A Nontransported: Percentages of cassava which are not transported from the farm were obtained from Census SWD \#2B PRD-CULT-10A. 


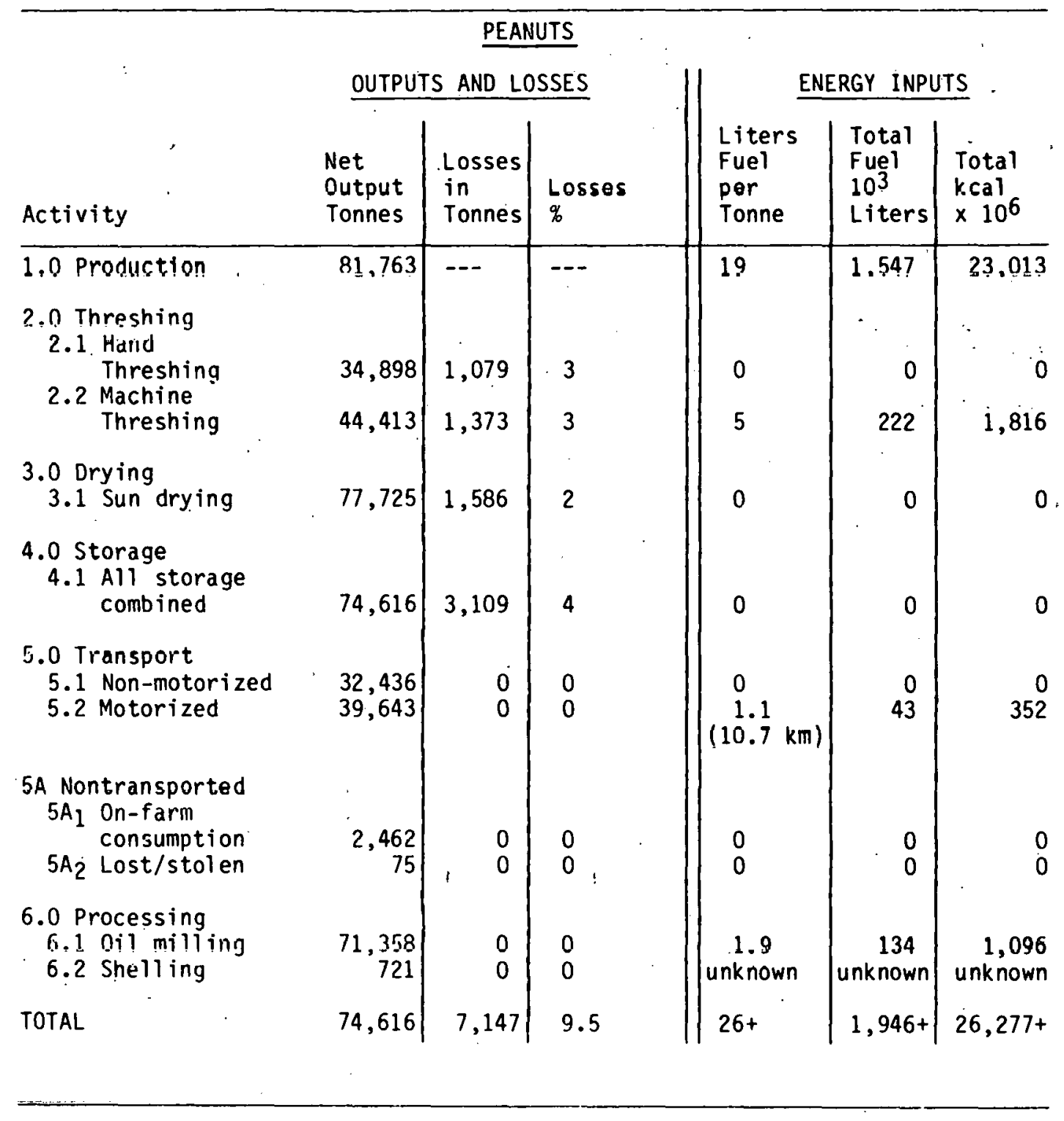




\section{Peanuts Footnotes}

1.0 Production: See production data sheet

Pre-harvest losses of $36.2 \%$ as follows:

insects: $4.4 \%$

diseases: $20.7 \%$

weeds: $\quad 11.1 \%$

Data from Groundnut losses for North and Central America.

In: H.H. Cramer, 1967, Plant Protection and World Crop Production, Farbenfabriken, Bayer AG, Leuerkusen.

2.0 Threshing and

3.0 Drying:

Losses for threshing and drying of 5\% from Senegal study (assumes $2 \%$ for drying and $3 \%$ for threshing). For machine threshing, 5 iters of fuel per tonnes is assumed usage. From Senegal study data for rice threshing. Fuel energy equivalent: 1 liter of gasoline contains 8.179 kCal of energy. (From D. Pimente), 1979. For reference see footnote 6 of production footnotes). Assumes production of $1.1,1.2,1.5,1.6$ is machine-threshed and production of $1.3,1.4,1.7,1.8$ is hand threshed.

4.0 Storage:

Assumes 4\% losses as follows: Average postharvest loss from NAS study: $\quad 9 \%$ Less threshing and $5 \%$ Storage loss $4 \%$

Losses from NAS study: National Academy of Sciences, 1978, Postharvest Food Losses in Developing Countries, NAS, Washington, D.C.

5.0 Transport: Percentages for motorized and nonmotorized transport from Census SWD \#5 Table MRC-CULT-1. Average distance transported $=10.7 \mathrm{~km}$. From SWD \#5 Table MRC-CULT-1.

Energy used: $0.83 \mathrm{kcal} / \mathrm{kg} / \mathrm{km}$. From D. Pimentel, Energy used for transporting supplies to the farm, in 0 . Pimentel (Ed.), 1979, Energy Utilization in Agriculture, CRC Press, Boca Raton, Florida, in press.

$0.83 \mathrm{kcal} / \mathrm{kg} / \mathrm{km}=830 \mathrm{kcal} /$ tonne $/ \mathrm{km}$

$830 \mathrm{kcal} /$ tonne $/ \mathrm{km}$ - .10 1. gas/tonne $/ \mathrm{km}$. (asumes 1 1. gas contains $8,179 \mathrm{kcal}$ of energy -- see threshing/drying footnote for reference).

5A Not transported: Percentages for these usages, and hence amounts, obtained from Census SWD \#2B, table PRD-CULT-10A. 
6.0 Processing: Assumes from senegal study, that $1 \%$ of available production goes to shelled nuts, and that $99 \%$ goes to oil milling.

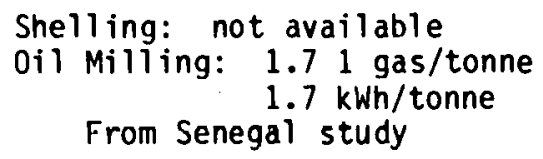

From Table C-1: Energy Utilization in Agriculture, by $D$. Pimental

1.71 . gasol ine/tonne: $13904 \mathrm{kcal} /$ tonne $1.7 \mathrm{kWh} /$ tonne $=\quad 1460 \mathrm{kcal} /$ tonne TOTAL: $\quad 15364 \mathrm{kcal} / \mathrm{tonne}$ for oil milling

$1.7 \mathrm{kWh} \quad .18 \quad 1$ gas equivalent. Therefore, total equivalent amount of 1 iquid fuel for oil milling $=1.7 \times$ $0.18=1.88$. . 


\begin{tabular}{|c|c|c|c|c|c|c|}
\hline \multirow[b]{3}{*}{ Activity } & \multicolumn{3}{|c|}{ PLANTAIN } & & & \\
\hline & \multicolumn{3}{|c|}{ OUTPUTS AND LOSSES } & \multicolumn{3}{|c|}{ ENERGY INPUTS } \\
\hline & $\begin{array}{l}\text { Net } \\
\text { Output } \\
\text { Units } \\
\times 10^{6}\end{array}$ & $\begin{array}{l}\text { Losses } \\
\text { in } \\
\text { Units } \\
\times 10^{6}\end{array}$ & $\begin{array}{l}\text { Losses } \\
\%\end{array}$ & $\begin{array}{l}\text { Liters } \\
\text { Fuel } \\
\text { per Unit } \\
x 10^{6}\end{array}$ & $\begin{array}{l}\text { Total } \\
\text { Fuel } \\
10^{3} \\
\text { Liters }\end{array}$ & $\begin{array}{l}\text { Total } \\
\text { kcal } \\
\times 10^{6}\end{array}$ \\
\hline 1.0 Production & 3,000 & -- & --- & 1459 & 4,377 & 39,699 \\
\hline 2.0 Storage & 2,700 & 300 & 10 & 0 & 0 & 0 \\
\hline $\begin{array}{l}\text { 3.0 Transport } \\
\text { 3.1 Nonmotorized } \\
\text { 3.2 Motorized }\end{array}$ & $\begin{array}{l}773 \\
685\end{array}$ & $\begin{array}{l}0 \\
0\end{array}$ & $\begin{array}{l}0 \\
0\end{array}$ & $\begin{array}{l}0 \\
\text { Unknown }\end{array}$ & $\begin{array}{c}0 \\
\text { Unknown }\end{array}$ & $\begin{array}{r}0 \\
\text { Unknown }\end{array}$ \\
\hline $\begin{array}{c}3 A_{\text {Nontransported }} \\
3 A_{1} \text { On-farm } \\
\text { consumption } \\
3 A_{2} \text { Animal Feed } \\
3 A_{3} \text { Lost } / \text { stolen } \\
\text { or unsold }\end{array}$ & $\begin{array}{r}1,212 \\
3 \\
27\end{array}$ & $\begin{array}{l}0 \\
0 \\
0\end{array}$ & $\begin{array}{l}0 \\
0 \\
0\end{array}$ & $\begin{array}{l}0 \\
0 \\
0\end{array}$ & $\begin{array}{l}0 \\
0 \\
0\end{array}$ & $\begin{array}{l}0 \\
0 \\
0\end{array}$ \\
\hline TOTAL & $.2,700$ & 300 & 10 & $1621+$ & $4,377+$ & $39,699+$ \\
\hline
\end{tabular}

\section{Plantain Footnotes}

1.0 Production: See production data sheet. Pre-harvest losses from: Cramer, H.H., 1967, Plant Protection and World Crop Production. Crop Protection Advisory Department of Farbenfabriken Bayer AG, Leuerkusen, p. 286. Assumes that losses in plantains same as those which occur in bananas.

Losses due to: insect pests $=5 \%$

diseases $\quad=25 \%$

weeds $\quad=3 \%$

2.0 Storage: Losses based upon data from Dominican Republic. From: National Academy of Sciences, 1978, Postharvest Food Losses in Developing Countries, p. 112.

3.0 Transport: Percentages of motorized vs nonmotorized transport from Census SWD \#5 MRC-CULT-1. Average distance to market of $7.4 \mathrm{~km}$ also from Census SWD \#5. Energy inputs unknown due to lack of information regarding weights of "units."

3A Nontransported: Percentages of plantains which are not transported from the farm were obtained from Census SWD \#2B PRD-CULT-10A. 
1

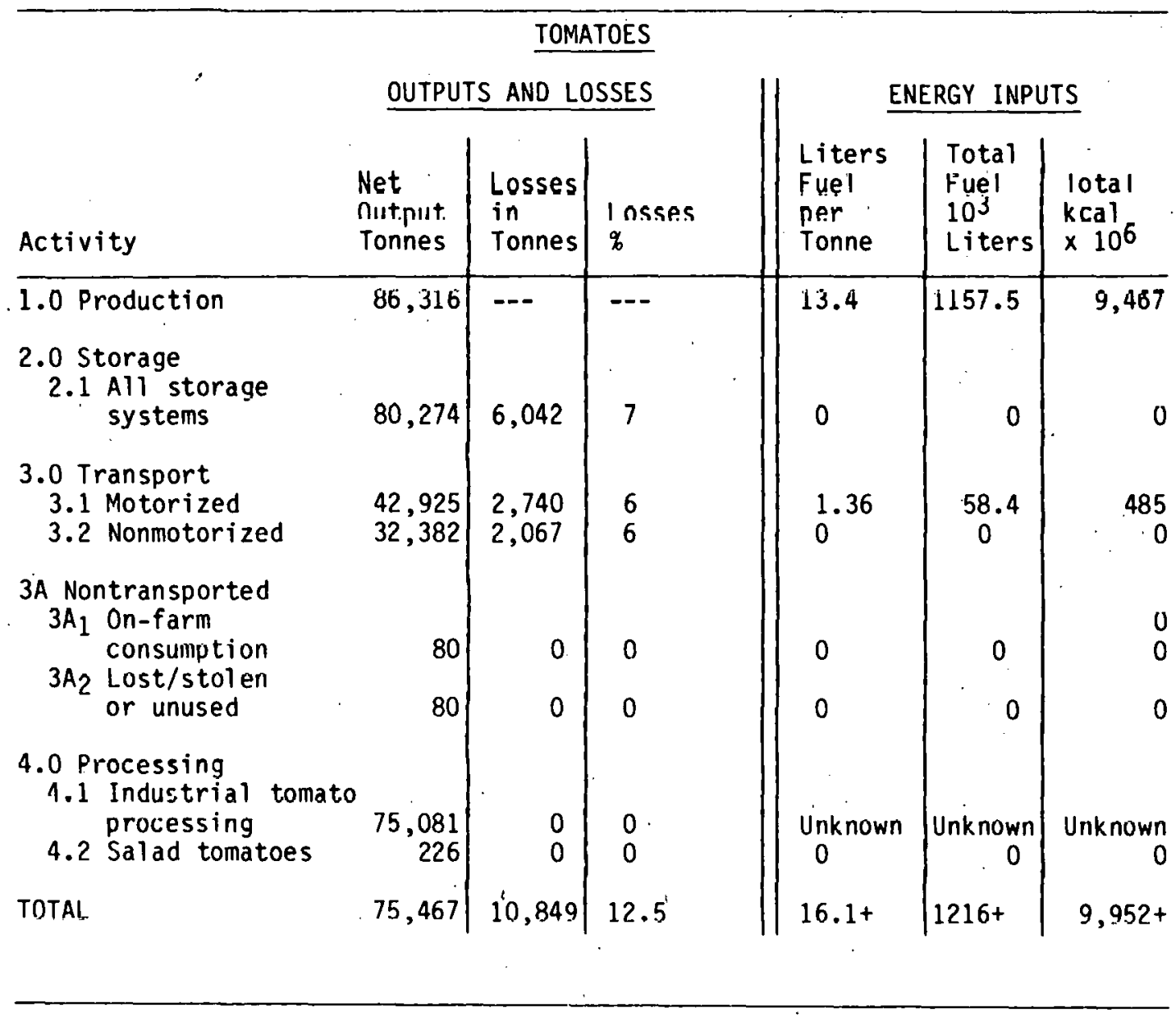




\section{Tomatoes Footnotes}

1.0 Production: See production data sheet.

2.0 Preharvest losses: of $30.1 \%$ as follows:

$\begin{array}{lr}\text { Insects: } & 4.4 \% \\ \text { Diseases: } & 20.7 \% \\ \text { Weeds: } & 11.1 \%\end{array}$

Based on losses from South American tomato production. In H.H. Cramer, 1967, Plant Protection and World Crop Production, Farbenfabriken Bayer AG.

3.0 Storage:

Assumes one basic system of storage. NAS study gives $13 \%$ as post-harvest loss for tomato production in Dominican Republic.

Assumes $7 \%$ of loss occurs in storage and remaining $6 \%$ of loss occurs in transport.

NAS source: National Academy of Sciences, 1978, Postharvest Food Losses in Developing Countries, NAS, Washington, D.C.

4.0 Transport: Percentages for motorized and non-motorized transport from Census SWD \#5 Table MRC-CULT-1. Average distance transported $=13.6 \mathrm{~km}$. From Census SWD \#5 Table MRC-CULT-1.

Energy used: $0.83 \mathrm{kcal} / \mathrm{kg} / \mathrm{km}$. From: D. Pimentel, Energy used for transporting supplies to the farm, in $D$. Pimentel (Ed.), Energy Utilization in Agriculture, CRC Press, Boca Raton, FTorida, in press.

$0.83 \mathrm{kcal} / \mathrm{kg} / \mathrm{km}$ - $830 \mathrm{kcal} /$ tonne $/ \mathrm{km}$.

$830 \mathrm{kcal} /$ tonne $/ \mathrm{km}=.101 \mathrm{gas} /$ tonne $/ \mathrm{km}$. (assumes 11 of gas contains $8179 \mathrm{kcal}$ of energy). For reference, see footnote \#6 in production footnotes.

Transportation-related losses of $6 \%$ from NAS source for Dominican Republic tomato data. For reference and further explanation, see ahove footnote for storage.

4A Nontransported: Percentages for these usages and hence amounts, obtained from Census SWD \#2B table PRD-CULT-10A.

5.0 Processing: Percentages, and hence amounts, of fresh tomato production vs processed tomato production were obtained from the Census SWD \#2 Table PRD-CULT-1.

Note: the nature of the processing and final products for "Industrial tomatoes" was not known. Therefore, the output for this system is simply titled, "Processed Tomatoes," and the output quantity is identical to the input quantity (i.e., it is assumed that there are no losses in this system). Also, for this reason, energy inputs for industrial tomato processing are listed as unknown. 


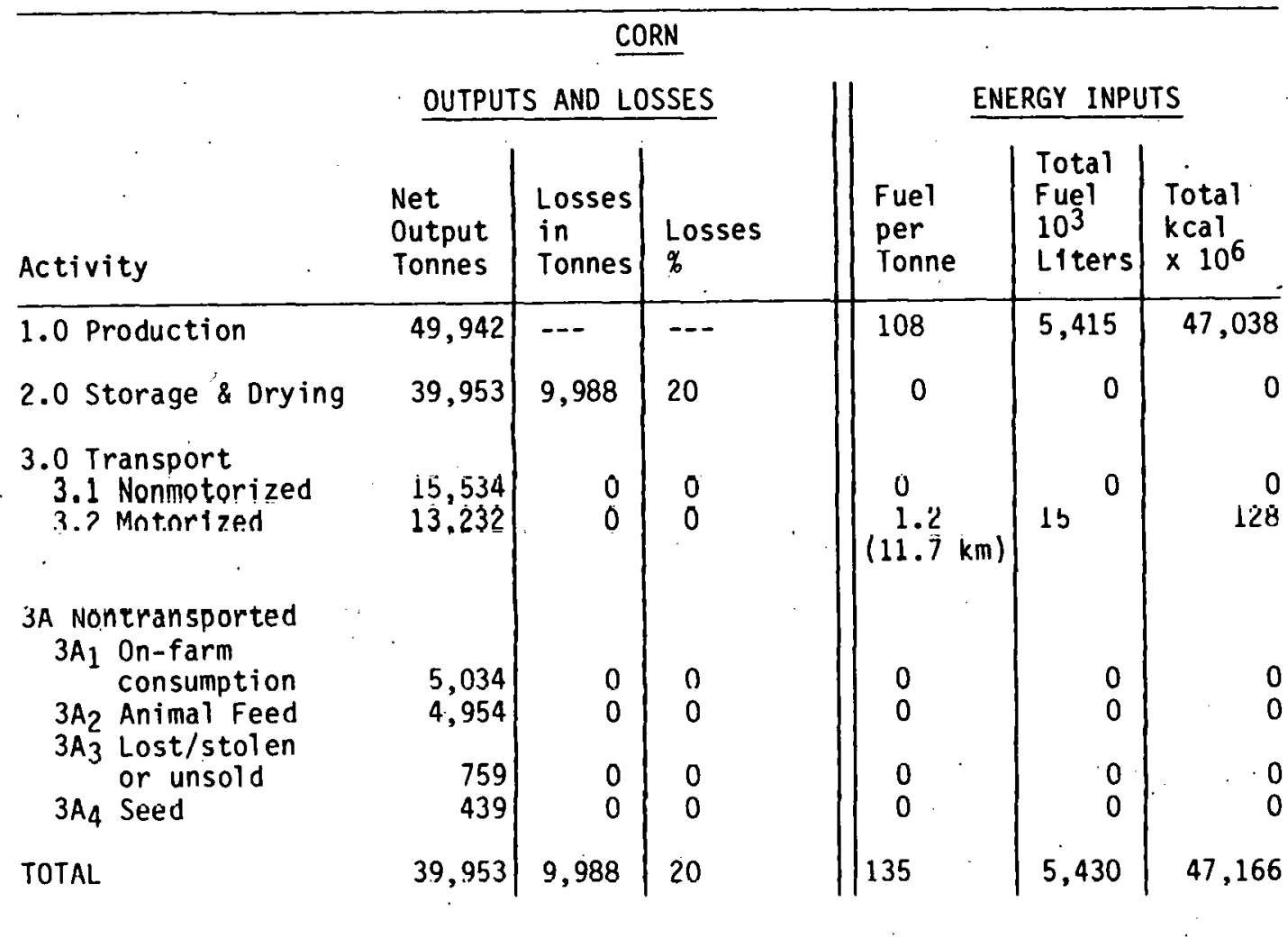

\section{Corn Footnotes}

1.0 Production: See production data sheet. Pre-harvest losses from: Cramer, H.H., 1967, Plant Protection and World Crop Production. Crop Protection Advisory Department of Farbenfabriken Bayer $\wedge G$, Leuerkusen, p. 266 .

Losses due to: insect pests $=20 \%$

diseases $=10 \%$

weeds $\quad=10 \%$

2.0 Storage \&

Losses based upon data from Dominican Republic and other American countries. Trom: National Acadcmy of Scicnces. 1978. Postharvest Food Losses in Developing Countries.

3.0 Transport: Percentages of motorized vs. non-motorized transport from Census SWD \#5 MRC-CULT-1. Average distance to market of $11.7 \mathrm{~km}$ al so from Census SWD \#5 MRC-CULT-1. Energy inputs based upon an average of $830 \mathrm{kcal} /$ tonne $/ \mathrm{km}$ to transport goods by truck (from: D. Pimentel, Energy used for transporting supplies to the farm, in D. Pimentel (Ed.) 1979. Energy Utilization in Agriculture, CRC Press, Boca Raton, FTorida, in press).

3A Nontransported: Percentages of beans which are not transported from the farm were obtained from Census SWD \#2B PRD-CULT-10A. 


\section{Production Footnotes}

1. Hectarage:

(a) Total from Table 8 (1974 data) of TVA study:

J. Free, C. Kresge, and T. H. Foster, Dominican Republic Fertilizer Situation--A Description, Analysis, and Recommendation, National Fertilizer Development Center Bulletin 4-103, Tennessee Valley Authority, Muscle Shoals, Ala., January 1976.

(b) Relative percentages of fertilized and unfertilized land based upon Table 8 of TVA study.

(c) Relative percentages of interplanted and not interplanted crop land based upon data from:

U.S. Agency for International Development, Dominican Republic Agricultural Sectoral Analysis Series: Statistical Working Document 2-B, Table PRD-CULT-5, U.S. Bureau of the Census, washington, D.C, 1977.

(d) Note: it was assumed that production techniques 1.1 and 1.5 were each employed on less than $1 \%$ of the hectarage.

2. Yield:

(a) Based upon Tables 12 and 13 of TVA study (see footnote 1 a).

3. Production:

(a) Area (ha) $x$ Yield $(\mathrm{kg} / \mathrm{ha})$. Checked against TVA study, Table 3 (1972 production figures). For reference, see footnote 1 a.

[Note: for plantains only, both yield and production data are given in terms of "units" rather than kilograms].

4. Fertilizer:

(a) Fertilizer usage data from TVA study, Table 11 (see footnote la for complete reference).

5. Fertilizer:

(a) Total tonnes $=$ area $\times$ usage $/$ ha .

6. Fertilizer Energy:

Assumes following values for energy consumption embodied in fertilizer:

(a) Nitrogen: 13,900 $\mathrm{kcal} / \mathrm{kg}$

(b) Phosphorus: 2,400 kcal/kg

(c) Potassium: $1,300 \mathrm{kcal} / \mathrm{kg}$

From Lockeretz in: D. Pimental (Ed.) 1979, Energy Utilization in Agriculture, CRC Press, Boca Raton, Fla., in press. 
7. Fuel usage for highly mechanized technique based upon following:

(a) Plaintains: manuscript by F. W. Liu, Dept. of Pomology, Cornell University: Energy requirements for banana production in selected areas, value of 150 /ha from Taiwanese data for banana production.

(b) Tomato: $628 \mathrm{l} / \mathrm{ha}$ from data on U.S. tomato production in:

D. Pimentel, 1979, Food, Energy, and Society, Edward Arnold (Publ ishers) Ltd., Londur.

(i) Cassava: $150 \mathrm{l} / \mathrm{ha}$. Estimatod by 0 . Pimentel.

(d) Peanuts: $63 \mathrm{l} / \mathrm{ha}$. From data for U.S. peanut production. From $D$. Fimente), 1979, (See footnote $7 b$ for complete reference.)

(e) Corn: $206 \mathrm{l} / \mathrm{ha}$. From data for U.S. corn production in: D. Pimental, 1979, The energy crisis: its impact on agriculture. Scienza \& Technica 76, Mondadori, Milan, in press.

(f) Beans: 178 l/ha. From data for U.S. potato productiun. (For reference, see footnote $7 \mathrm{e})$.

(g) Sweet Potatoes: $206 \mathrm{l} / \mathrm{ha}$. From data for U.S. potato production. (For reference, see footnote $7 \mathrm{e}$ ).

(h) Rice: $225 \mathrm{l} / \mathrm{ha}$. From data for U.S. rice production. (Fur reference, see footnote $7 \mathrm{e})$.

(i) Sugar Cane: $338 \mathrm{l} / \mathrm{ha}$. From data for sugarcane production in Louisiana. In Energy Inputs and Output for Sugarcane in Luuisiana. Manuscript by Ray Ricaud, Loulsiana Agricultural Experiment Station, Baton Rouge, Louisiana.

[Note: it is assumed that fuel usage for partially mechanized systems is half of that for the fully mechanized system. Furthermore, it is assumed that. fuel usage for nonmechanized cropping systems is zero].

8. Derived as follows: Fuel usage per ha $x$ total No. of hectares.

9. Assumes that $1 \mathrm{l}$ of gasol ine contains $8179 \mathrm{kcal}$ of energy. From Table C-1: Energy supplies and efficiency. From 0. Pimente1. 1979, (For reference $\theta$, see Fontnnte. 6). 


\section{ENERGY CONVERSION TABLES}

\begin{tabular}{|c|c|c|}
\hline Energy Resource & Unit & joules $\times 10^{6}$ \\
\hline Crude $0 i 1$ & Barrel & 6,120 \\
\hline $\begin{array}{l}\text { Petrol eum Products } \\
\text { LP Gas (propane/butane) } \\
\text { Gasol ine } \\
\text { Kerosene } \\
\text { Aviation Fuels } \\
\text { Distillate (diese1, gas oil, } \\
\text { heating oil, No. } 2 \text { oil) } \\
\text { Residual (heavy oil, bunker- } \\
\text { fuel, No. 5-6) }\end{array}$ & $\begin{array}{l}\text { Barrel } \\
\text { Barrel } \\
\text { Barrel } \\
\text { Barrel } \\
\text { Barrel } \\
\text { Barrel }\end{array}$ & $\begin{array}{l}4,230 \\
5,540 \\
5,980 \\
5,540 \\
6,145 \\
6,630\end{array}$ \\
\hline Barrel of $0 i 1$ Equivalent & & 6,120 \\
\hline $\begin{array}{l}\text { Coal } \\
\text { Bituminous } \\
\text { U.S. Average } \\
\text { Lignite } \\
\text { U.S. }\end{array}$ & $\begin{array}{l}\text { Metric Tons } \\
\text { Metric Tons }\end{array}$ & $\begin{array}{l}27,900 \\
16,300\end{array}$ \\
\hline $\begin{array}{l}\text { Firewood } \\
\text { Charcoal } \\
\text { Bagasse } \\
\text { Natural Gas }\end{array}$ & $\begin{array}{l}\text { Metric Tons } \\
\text { Metric Tons } \\
\text { Metric Tons } \\
\text { Cubic Meters } \\
\text { Cubic Foot }\end{array}$ & $\begin{array}{l}14,000^{\mathrm{a}} \\
28,000^{\mathrm{a}} \\
7,000-11,000^{\mathrm{a}} \\
37,240 \\
1,087\end{array}$ \\
\hline
\end{tabular}

MISCELLANEOUS CONVERSIONS

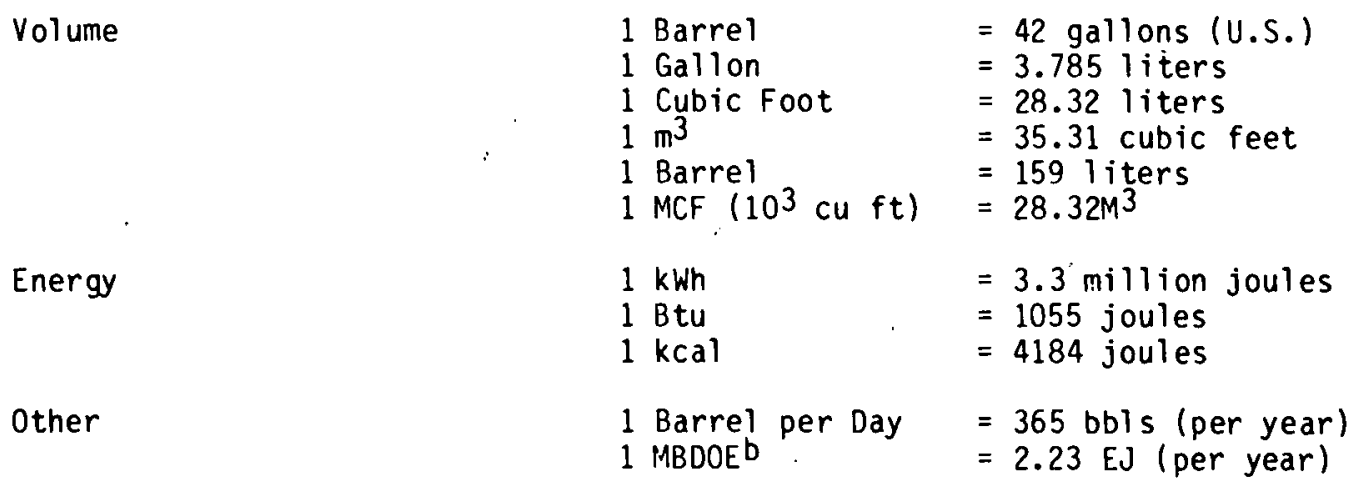

Approximate value or range.

DMBDOE: million barrels per day oil equivalent, used frequently in energy statistics. 